\title{
JV TASK 90 - ACTIVATED CARBON PRODUCTION FROM NORTH DAKOTA LIGNITE
}

\author{
Final Report \\ (for the period June 1, 2005, through January 31, 2008) \\ Prepared for: \\ AAD Document Control \\ U.S. Department of Energy \\ National Energy Technology Laboratory \\ 626 Cochrans Mill Road \\ PO Box 10940, MS 921-107 \\ Pittsburgh, PA 15236-0940 \\ Cooperative Agreement No. DE-FC26-98FT40321 \\ Project Manager: John Stipanovich
}

Prepared by:

Steven A. Benson Charlene R. Crocker

Rokan Zaman

Sheila K. Hanson

Mark A. Musich

Edwin S. Olson

Energy \& Environmental Research Center

University of North Dakota

15 North 23rd Street, Stop 9018

Grand Forks, ND 58202-9018

Srivats Srinivasachar

President

Envergex LLC

10 Podunk Road

Sturbridge, MA 01566

Louis T. Barry, P.E.

Chavond-Barry Engineering Corporation

400 County Route 518, PO Box 205

Blawenburg, NJ 08504-0205 


\section{DOE DISCLAIMER}

This report was prepared as an account of work sponsored by an agency of the United States Government. Neither the United States Government, nor any agency thereof, nor any of their employees makes any warranty, express or implied, or assumes any legal liability or responsibility for the accuracy, completeness, or usefulness of any information, apparatus, product, or process disclosed or represents that its use would not infringe privately owned rights. Reference herein to any specific commercial product, process, or service by trade name, trademark, manufacturer, or otherwise does not necessarily constitute or imply its endorsement, recommendation, or favoring by the United States Government or any agency thereof. The views and opinions of authors expressed herein do not necessarily state or reflect those of the United States Government or any agency thereof.

This report is available to the public from the National Technical Information Service, U.S. Department of Commerce, 5285 Port Royal Road, Springfield, VA 22161; phone orders accepted at (703) 487-4650.

\section{NDIC DISCLAIMER}

This report was prepared by the Energy \& Environmental Research Center (EERC) pursuant to an agreement partially funded by the Industrial Commission of North Dakota, and neither the EERC nor any of its subcontractors nor the North Dakota Industrial Commission nor any person acting on behalf of either:

(A) Makes any warranty or representation, express or implied, with respect to the accuracy, completeness, or usefulness of the information contained in this report, or that the use of any information, apparatus, method, or process disclosed in this report may not infringe privately owned rights; or

(B) Assumes any liabilities with respect to the use of, or for damages resulting from the use of, any information, apparatus, method, or process disclosed in this report.

Reference herein to any specific commercial product, process, or service by trade name, trademark, manufacturer, or otherwise does not necessarily constitute or imply its endorsement, recommendation, or favoring by the North Dakota Industrial Commission. The views and opinions of authors expressed herein do not necessarily state or reflect those of the North Dakota Industrial Commission

\section{EERC DISCLAIMER}

LEGAL NOTICE. This research report was prepared by the Energy \& Environmental Research Center (EERC), an agency of the University of North Dakota, as an account of work sponsored by DOE and NDIC. Because of the research nature of the work performed, neither the EERC nor any of its employees makes any warranty, express or implied, or assumes any legal liability or responsibility for the accuracy, completeness, or usefulness of any information, apparatus, product, or process disclosed or represents that its use would not infringe privately owned rights. Reference herein to any specific commercial product, process, or service by trade name, trademark, manufacturer, or otherwise does not necessarily constitute or imply its endorsement or recommendation by the EERC. 


\title{
JV TASK 90 - ACTIVATED CARBON PRODUCTION FROM NORTH DAKOTA LIGNITE
}

\begin{abstract}
The Energy \& Environmental Research Center (EERC) has pursued a research program for producing activated carbon from North Dakota lignite that can be competitive with commercialgrade activated carbon. As part of this effort, small-scale production of activated carbon was produced from Fort Union lignite. A conceptual design of a commercial activated carbon production plant was drawn, and a market assessment was performed to determine likely revenue streams for the produced carbon.
\end{abstract}

Activated carbon was produced from lignite coal in both laboratory-scale fixed-bed reactors and in a small pilot-scale rotary kiln. The EERC was successfully able to upgrade the laboratory-scale activated carbon production system to a pilot-scale rotary kiln system.

The activated carbon produced from North Dakota lignite was superior to commercial grade DARCO ${ }^{\circledR}$ FGD and Rheinbraun's HOK activated coke product with respect to iodine number. The iodine number of North Dakota lignite-derived activated carbon was between 600 and $800 \mathrm{mg} \mathrm{I} / \mathrm{g}$, whereas the iodine number of DARCO FGD was between 500 and $600 \mathrm{mg} \mathrm{I} / \mathrm{g}$, and the iodine number of Rheinbraun's HOK activated coke product was around $275 \mathrm{mg} \mathrm{I} / \mathrm{g}$.

The EERC performed both bench-scale and pilot-scale mercury capture tests using the activated carbon made under various optimization process conditions. For comparison, the mercury capture capability of commercial DARCO FGD was also tested. The lab-scale apparatus is a thin fixed-bed mercury-screening system, which has been used by the EERC for many mercury capture screen tests. The pilot-scale systems included two combustion units, both equipped with an electrostatic precipitator (ESP). Activated carbons were also tested in a slipstream baghouse at a Texas power plant. The results indicated that the activated carbon produced from North Dakota lignite coal is capable of removing mercury from flue gas. The tests showed that activated carbon with the greatest iodine number was superior to commercial DARCO FGD for mercury capture.

The results of the activated carbon market assessment indicate an existing market for water treatment and an emerging application for mercury control. That market will involve both existing and new coal-fired plants. It is expected that $20 \%$ of the existing coal-fired plants will implement activated carbon injection by 2015, representing about 200,000 tons of annual demand. The potential annual demand by new plants is even greater.

In the mercury control market, two characteristics are going to dominate the customer's buying habit-performance and price. As continued demonstration testing of activated carbon injection at the various coal-fired power plants progresses, the importance of fuel type and plant configuration on the type of activated carbon best suited is being identified. 


\section{TABLE OF CONTENTS}

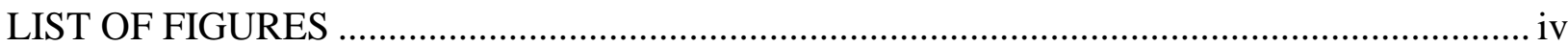

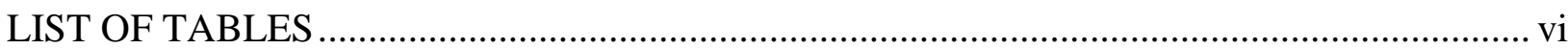

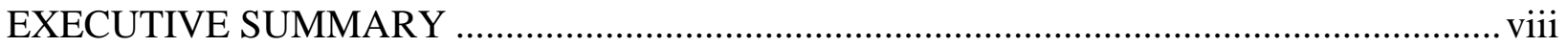

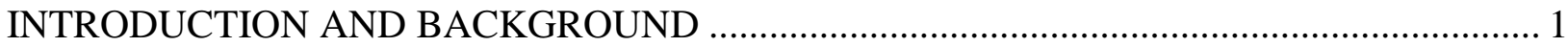

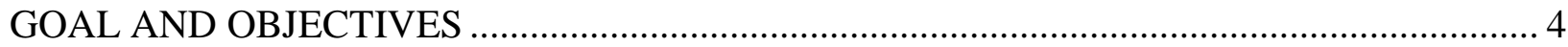

Task 1 - Pilot-Scale Optimization and Production ............................................................ 5

Task 2 - Sorbent Property Investigation ......................................................................... 5

Task 3 - Conceptual Design of a Commercial Plant Producing Activated Carbon from

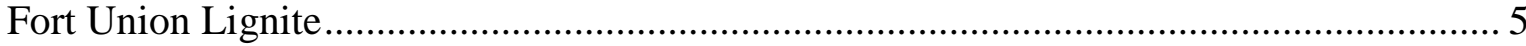

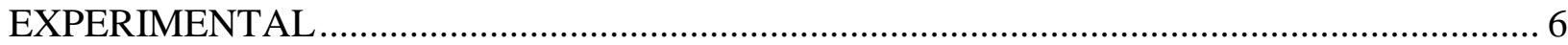

Task 1 - Pilot-Scale Optimization and Production ....................................................... 6

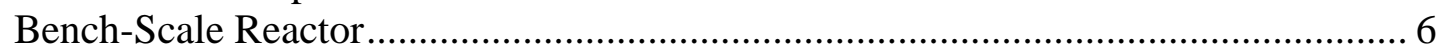

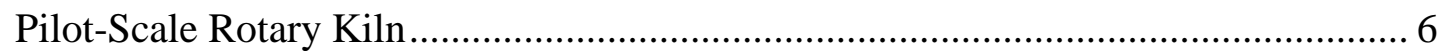

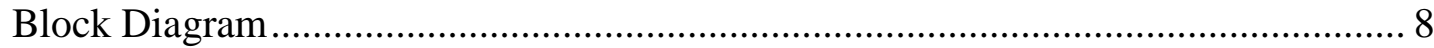

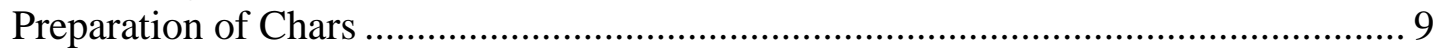

Preparation of Activated Carbons....................................................................... 9

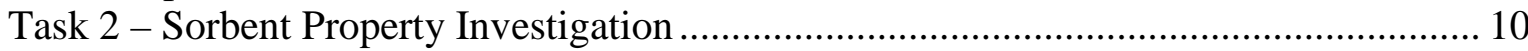

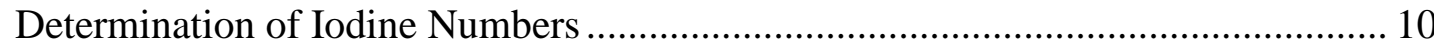

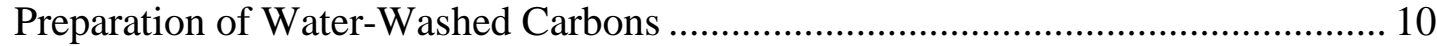

Preparation of HCl-Washed Carbons ….................................................................... 10

Preparation of HCl-Impregnated Carbons ............................................................ 10

Bench-Scale Mercury Test System..................................................................... 11

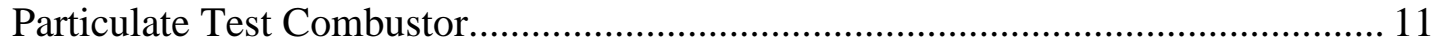

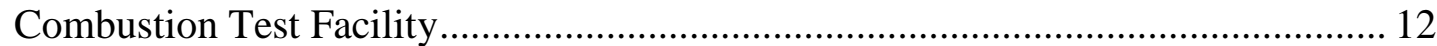

Task 3 - Conceptual Design of a Commercial Plant Producing Activated Carbon from

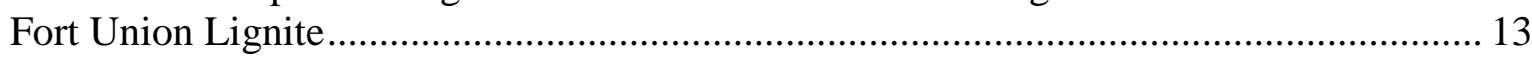

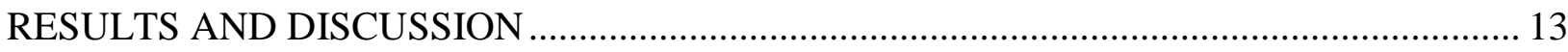

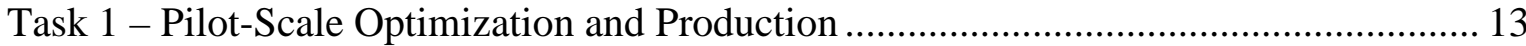

Bench-Scale Optimization and Production.......................................................... 13

Pilot-Scale Optimization and Production .......................................................... 17

Carbonization of North Dakota Lignite ............................................................ 17

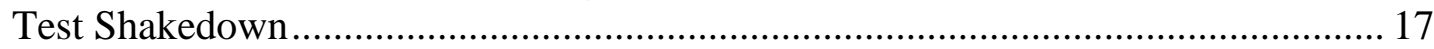

Carbonization Process Optimization Tests ........................................................... 18

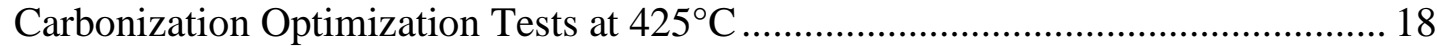

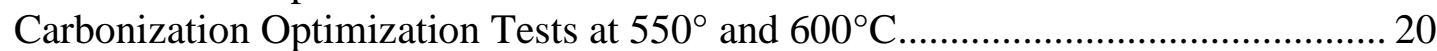

Steam Activation of Carbonized Char ............................................................... 21

Continued ... 


\section{TABLE OF CONTENTS (continued)}

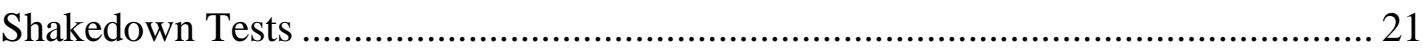

Activation Process Optimization Tests.................................................................... 22

Effect of Steam Flow Rate and Temperature .......................................................... 22

Effect of Residence Time and Temperature ……………........................................ 23

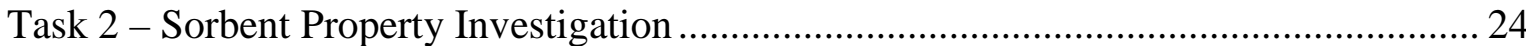

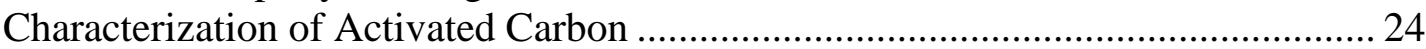

Bench-Scale Mercury Capture Tests ......................................................................... 24

Preliminary Bench-Scale Mercury Capture Tests ..................................................... 24

Mercury Capture Tests for Carbon Activated at $840^{\circ}$ and $900^{\circ} \mathrm{C}$ in the

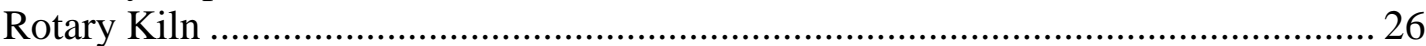

Mercury Capture Tests for Activated Carbon Made in the 1-inch Reactor................ 26

Mercury Capture Tests for Carbon Activated at Different Residence Times and

Temperatures in the Rotary Kiln ............................................................................. 28

Pilot-Scale and Slipstream Testing of Activated Carbon ........................................... 29

PTC Activated Carbon Test............................................................................................ 29

Slipstream Baghouse Test at a Texas Power Plant ................................................ 30

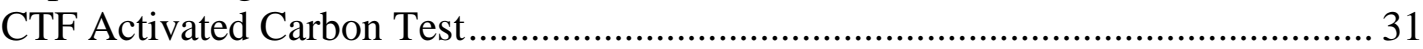

CTF Test Using Carbon Activated at $900^{\circ} \mathrm{C}$........................................................... 34

Task 3 - Conceptual Design of a Commercial Plant Producing Activated Carbon from

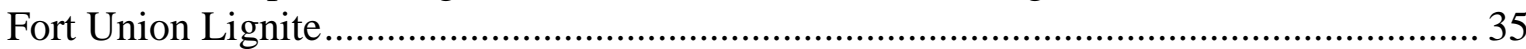

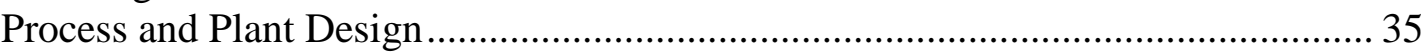

Economic Feasibility Study ……………………………..................................... 35

Market Assessment of Lignite-Derived Activated Carbon .......................................... 36

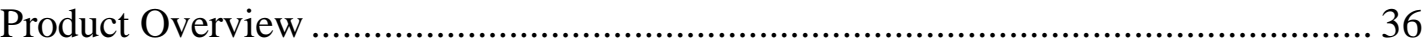

Plain Powdered Activated Carbon............................................................................ 36

Impregnated Powdered Activated Carbon.................................................................. 37

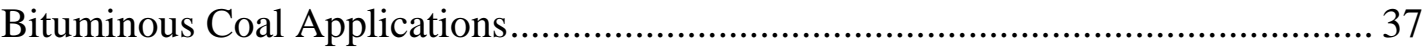

Concrete-Friendly Activated Carbons …………….................................................. 37

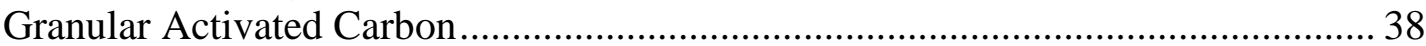

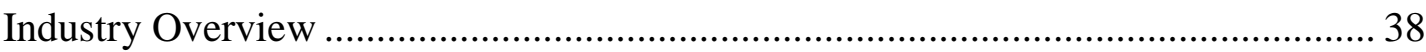

Demand for Activated Carbon....................................................................................... 39

Market Segments and Identification of Market Opportunities .................................... 40

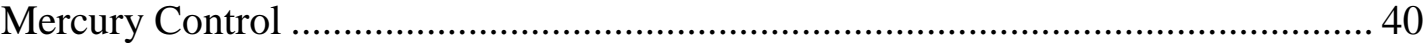

Activated Carbon Injection Technology for Mercury Control .................................... 40

New Coal-Fired Power Plants Application for Mercury Control ................................ 42

Existing Coal-Fired Power Plants Application for Mercury Control ......................... 44



Competitive Overview..................................................................................... 47

New Product Development - Mercury Control .......................................................... 48

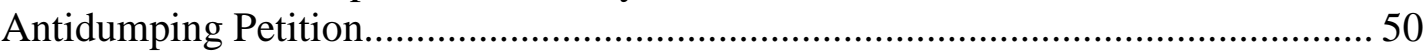

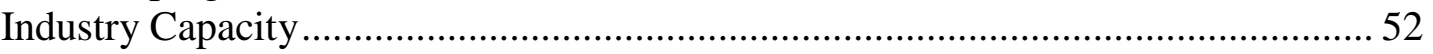

Continued ... 


\section{TABLE OF CONTENTS (continued)}

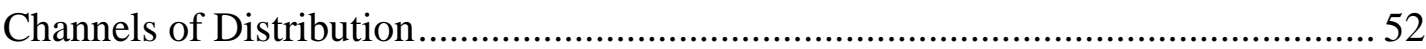

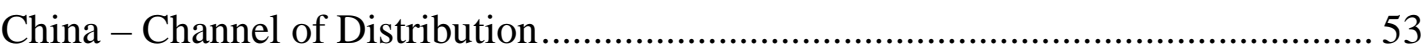

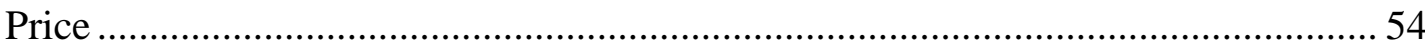

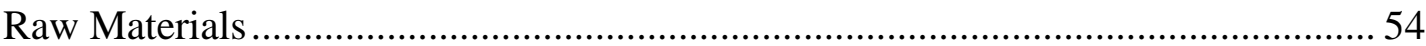

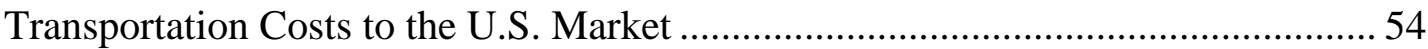

U.S. Inland Transportation Costs................................................................. 54

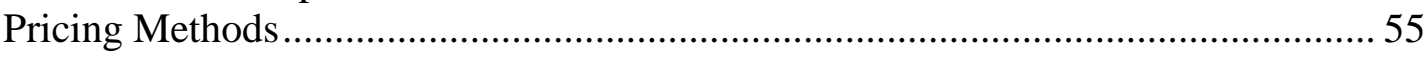

Water Treatment Applications - Pricing and Bid Process ..................................... 56

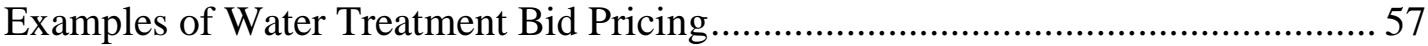

Identification of Barriers to Market Entry …......................................................... 57

Recommendations for Market Strategies ................................................................. 58

Market Segmentation Focus ...................................................................... 58

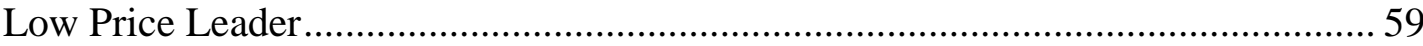

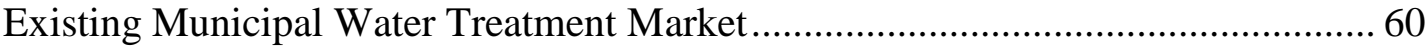

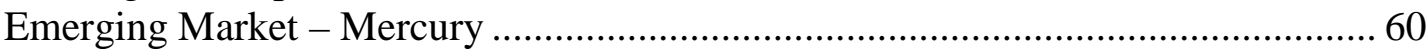

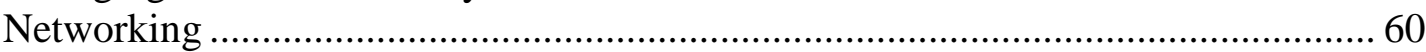

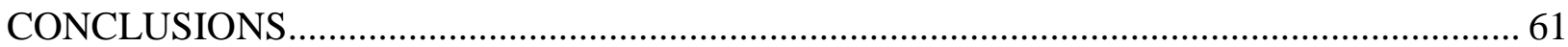

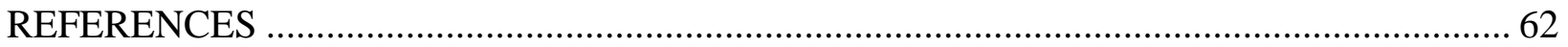




\section{LIST OF FIGURES}

1 Flow diagram of the current production and use of activated carbon..................................... 3

2 Demand for activated carbon in the United States............................................................ 4

3 Schematic of the rotary kiln reactor system..................................................................... 7

$4 \quad$ The rotary kiln reactor system installed in the EERC pilot plant .......................................... 7

$5 \quad$ Block diagram of activated carbon production from coal .................................................... 8

$6 \quad$ Injection and sampling schematic of the PTC with an ESP................................................... 11

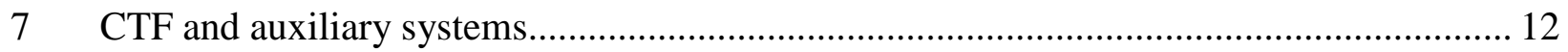

8 Iodine number and burnout rate of activated carbons prepared from Center lignite in a 1-in. reactor at various activation temperatures .................................................................... 16

9 Iodine number for samples of char and activated carbon generated in a pilot-scale rotary kiln from Center lignite compared to commercially available activated carbon .................. 25

10 Results of bench-scale mercury capture screening of initial carbons activated in the 1-in. bench-scale reactor and in the rotary kiln shakedown test under low-acid simulated flue gas conditions

11 Bench-scale mercury capture data for carbons activated at rotary kiln optimization conditions and DARCO FGD in a low-acid simulated flue gas

12 Results of bench-scale mercury capture screening of carbons activated in the 1-in. benchscale reactor under low-acid simulated flue gas conditions.

13 Bench-scale mercury capture data for carbons activated at rotary kiln optimization conditions

14 Mercury emissions from a pilot-scale ESP in a subbituminous coal flue gas during baseline conditions and injection of Center Mine lignite-derived carbon injection as a mercury

sorbent.

15 Mercury capture in a pilot-scale ESP in subbituminous coal flue gas using Center Mine lignite-derived and DARCO ${ }^{\circledR} \mathrm{Hg}$ activated carbon injection as mercury sorbents 30

Continued ... 


\section{LIST OF FIGURES (continued)}

16 Pilot-scale ESP (9) and full-scale TOXECON ${ }^{\mathrm{TM}}$ and ESP (10) mercury removal efficiencies as a function of activated carbon injection rate for DARCO Hg and Center lignite-derived activated carbon

17 Outlet mercury removal percentage beyond baseline in a slipstream baghouse at a Texas power plant in subbituminous coal-combusted flue gas using Center Mine lignite-derived and DARCO Hg carbon injection as mercury sorbents

18 Total gaseous mercury removal percentage beyond baseline in a pilot-scale ESP in using Center Mine lignite-derived and DARCO Hg carbon injection as mercury sorbents (combustion of Caballo coal in the CTF)

19 Outlet gaseous mercury concentration in a pilot-scale ESP using Center Mine lignite-derived and DARCO ${ }^{\circledR} \mathrm{Hg}$ carbon injection as mercury sorbents 33

20 Total gaseous mercury removal percentage beyond baseline in a pilot-scale ESP using Center Mine lignite-derived carbon made at $900^{\circ} \mathrm{C}$ and DARCO $\mathrm{Hg}$ carbon injection as mercury sorbents

21 Activated carbon injection technology for mercury control in coal-fired power plants...... 41

22 Proposed new coal-fired electric power generation capacity (21)....................................... 43

23 Geographical distribution of new coal-fired electric power generation capacity (21) ........ 43

24 Average domestic price of coal to industrial plants, 2003-2005 (32) ……………............. 55

25 Product mix and penetration and growth strategy for a North Dakota-based manufacturer of activated carbon. 


\section{LIST OF TABLES}

1 Coal Analysis of Hagel A Center Lignite ............................................................... 14

2 Test Matrix for Fixed-Bed Optimization of Center Lignite ........................................... 15

3 Test Matrix for Carbonization Optimization Tests in the Rotary Kiln ............................ 17

4 Test Conditions for Shakedown Carbonization Tests Using Hagel A Seam

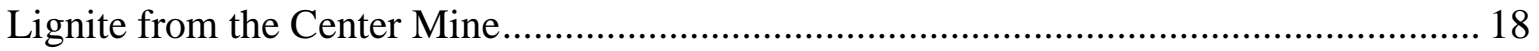

$5 \quad$ Coal Analysis of Hagel A Center Lignite ................................................................ 19

6 Test Conditions for Carbonization Tests Using Old Hagel A and

Hagel A (December 22, 2005) Seam Lignite from the Center Mine ................................ 19

$7 \quad$ Test Conditions for Carbonization Tests Using Two Types of Hagel

A Seam Lignite from the Center Mine ....................................................................... 20

8 Test Matrix for Steam Activation Optimization Tests in Rotary Kiln ............................. 21

9 Test Conditions for Shakedown Steam Activation Test Using Hagel A

Seam Lignite from the Center Mine ........................................................................ 21

10 Steam Activation Test Conditions for Optimization of Rotary Kiln

Parameters Such as Steam Flow Rate and Temperature ............................................ 22

11 Steam Activation Test Conditions for Optimization of Rotary

Kiln Parameters Such as Residence Time and Temperature ........................................... 23

12 Performance of Activated Carbon Prepared from North Dakota Lignite and

DARCO $^{\circledR} \mathrm{Hg}$ in a Slipstream Baghouse Containing Subbituminous

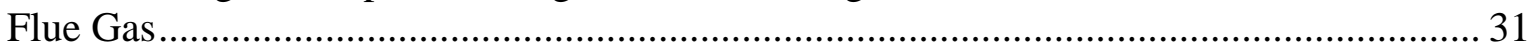

13 Activated Carbon Demand in Water Treatment........................................................... 39

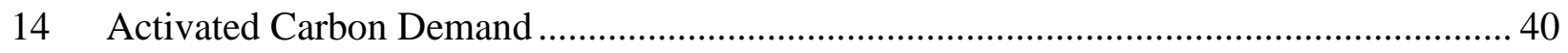

15 States with Aggressive Mercury Emission Regulations as of 2006............................... 44

16 States with Plans for Aggressive Mercury Emission Regulations .................................. 45

Continued... 


\section{LIST OF TABLES (continued)}

17 List of Plants Where Activated Carbon Injection Has Been Demonstrated ...................... 49

18 Activated Carbon: Chinese Production Capacity, Production, Shipments,

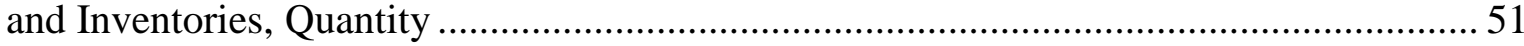

19 Activated Carbon: Chinese Production Capacity, Production, Shipments,

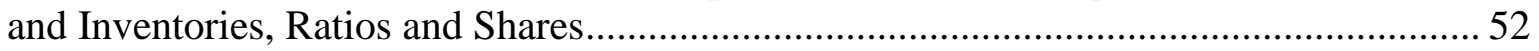

20 Activated Carbon: U.S. Producers' and U.S. Importers’ U.S. Shipments by Channels of Distribution, 2003-2005 ........................................................................... 54

21 Weighted Average F.O.B. Prices and Quantities of Domestic and Imported PAC by Quarters, January 2003-December 2005........................................................... 56 


\section{JV TASK 90 - ACTIVATED CARBON PRODUCTION FROM NORTH DAKOTA LIGNITE}

\section{EXECUTIVE SUMMARY}

The Energy \& Environmental Research Center (EERC) has pursued a research program for producing activated carbon from North Dakota lignite that can be competitive with commercialgrade activated carbon. As part of this effort, small-scale production of activated carbon was produced from Fort Union lignite. A conceptual design of a commercial activated carbon production plant was drawn, and a market assessment was performed to determine likely revenue streams for the produced carbon.

Activated carbon was produced from lignite coal in both laboratory-scale fixed-bed reactors and in a small pilot-scale rotary kiln. The activated carbon production process involved two main steps: 1) carbonization-driving out moisture and volatiles to obtain the fixed carbon portion of the coal and 2) activation-partial gasification with steam or carbon dioxide to open the pore structure and increase the surface area. The laboratory-scale tests were conducted to determine the optimum process conditions for activated carbon production and to guide the pilotscale optimization process conditions. The EERC was successfully able to upgrade the laboratory-scale activated carbon production system to a pilot-scale rotary kiln system. Pilotscale tests were conducted in a continuous rotary kiln system to determine the optimum process parameters for the production of activated carbon. The EERC conducted a series of optimization tests for both carbonization and steam activation processes in both laboratory-scale fixed-bed reactors and in the pilot-scale rotary kiln system. The EERC used surface area determination of iodine number as a quick quality indicator of the product produced during optimization tests. The iodine number is a measure of surface area of activated carbon. The iodine number is also widely used in the water treatment industry as a leading indicator of activated carbon quality.

The iodine numbers of char produced from one coal sample of Hagel A lignite from the Center Mine in the bench-scale reactor at temperatures of $400^{\circ}, 500^{\circ}$, and $600^{\circ} \mathrm{C}$ were 212,268 , and $290 \mathrm{mg} \mathrm{I}_{2} / \mathrm{g}$, respectively. The iodine numbers of char produced from the same coal in the pilot-scale rotary kiln at $550^{\circ} \mathrm{C}$ and $600^{\circ} \mathrm{C}$ were 350 and $380 \mathrm{mg} \mathrm{I}_{2} / \mathrm{g}$, respectively. Higher carbonization temperature drove out more volatiles from the carbon structure and produced higher surface areas. From the carbonization optimization tests conducted in both lab-scale and pilot-scale systems, the EERC found that $600^{\circ} \mathrm{C}$ was the best carbonization temperature.

The EERC produced activated carbon in both lab-scale and pilot-scale at different activation temperatures using the same char as feed material. The iodine numbers of the activated carbon produced in the pilot-scale reactor at 30-min residence time at $840^{\circ}$ and $900^{\circ} \mathrm{C}$ were 565 and $699 \mathrm{mg} \mathrm{I} / \mathrm{g}$, respectively. The higher activation temperatures generated more surface area than the lower activation temperatures. The same trend was also observed in the laboratory scale reactor. Another process comparison involved the production of activated carbon in the pilot-scale rotary kiln at different residence times with the same activation temperature using the same feed char. The iodine numbers of activated carbons produced at $900^{\circ} \mathrm{C}$ with 30-, 60-, and 90-min residence times were 699, 767, and $790 \mathrm{mg} \mathrm{I}_{2} / \mathrm{g}$, respectively. 
Longer residence time produced more surface area than shorter residence time. The same trend was also observed in bench-scale tests. From the activation optimization tests performed in both lab-scale and pilot-scale systems, the EERC found that higher activation temperature as well as longer residence time produced activated carbon with higher surface area. The best steam activation process conditions were $900^{\circ} \mathrm{C}$ as the activation temperature and 90-min residence time.

The activated carbon produced from North Dakota lignite was superior to commercial grade DARCO $^{\circledR}$ FGD and Rheinbraun's HOK activated coke product with respect to iodine number. The iodine number of North Dakota lignite-derived activated carbon was between 600 and $800 \mathrm{mg} \mathrm{I} / \mathrm{g}$, whereas the iodine number of DARCO FGD was between 500 and $600 \mathrm{mg} \mathrm{I} / \mathrm{g}$, and the iodine number of Rheinbraun's HOK activated coke product was around $275 \mathrm{mg} \mathrm{I} / \mathrm{g}$.

The EERC performed both bench-scale and pilot-scale mercury capture tests using the activated carbon made under various optimization process conditions. For comparison, the mercury capture capability of commercial DARCO ${ }^{\circledR}$ FGD was also tested. The lab-scale apparatus is a thin fixed-bed mercury-screening system, which has been used by the EERC for many mercury capture screen tests. The pilot-scale systems included the particulate test combustor (PTC) and the combustion test facility (CTF). Both the PTC and CTF are equipped with an electrostatic precipitator (ESP). The EERC also tested activated carbon in a slipstream baghouse at a Texas power plant. The bench-scale and pilot-scale tests performed at the EERC and in the slipstream baghouse test at a Texas power plant showed that the activated carbon produced from North Dakota lignite coal is capable of removing mercury from flue gas. The tests showed that activated carbon with the greatest iodine number was superior to commercial DARCO FGD for mercury capture.

The conceptual design feasibility study addressed the possibility of using local North Dakota lignite to produce powdered activated carbon. Plant production, annual operating cost and sales adjusted for maintenance downtime, and financing were used to determine a simple annual return on investment (ROI).

Mercury control is an emerging application that will be implemented in the U.S. utility industry, and the market will involve both existing and new coal-fired plants. The resurgence in the use of coal for new electric generation capacity (93 GWe at 153 plants proposed through 2015) represents a potential annual demand of about 300,000 tons. Mercury control for existing coal-fired power plants (installed capacity of $315 \mathrm{GWe}$ ) is also emerging, driven particularly by state-mandated environmental regulations. It is expected that $20 \%$ of the existing coal-fired plants will implement activated carbon injection by 2015 representing about 200,000 tons of annual demand. The mercury control market will provide expanded, high-value market opportunities for the proposed plant.

In the mercury control market, two characteristics are going to dominate the customer's buying habit-performance and price. As continued demonstration testing of activated carbon injection at the various coal-fired power plants progresses, the importance of fuel type and plant configuration on the type of activated carbon best suited is being identified. 
With all feasibility studies, several key assumptions have to be made. Future work should include pilot-plant demonstrations to confirm all technical assumptions as well as provide samples for customer development. 


\section{JV TASK 90 - ACTIVATED CARBON PRODUCTION FROM NORTH DAKOTA LIGNITE}

\section{INTRODUCTION AND BACKGROUND}

Since 2001, there has been growth in the use of carbon for gas- and liquid-phase cleanup such as flue gas desulfurization, water, and waste remediation treatments. Carbon derived from lignite is being used in novel ways to clean dioxins from scrap metal smelters in Europe. In the United States, the imports of carbon from China have doubled from 1996 to 2001 to 57 million pounds. Activated carbon use has grown steadily and is projected to total 450 million pounds in 2006.

Significant additional growth in the demand for carbon is anticipated as a result of the need to control the emission of mercury from coal-fired power plants. Activated carbon injection upstream of a particulate control device such as a fabric filter (FF) (baghouse) or an electrostatic precipitator (ESP) is showing significant promise for controlling mercury emissions (1). For activated carbons to be successful, they must effectively sorb $\mathrm{Hg}^{0}$ and $\mathrm{Hg}^{2+}$. Testing at the Energy \& Environmental Research Center (EERC) compared activated carbon sorbents prepared from Fort Union lignites to the commercial sorbent Norit America's DARCO ${ }^{\circledR}$ FGD (2). The DARCO FGD is derived from Texas lignite. Typically, Texas lignites have higher ash contents than North Dakota lignites. The North Dakota lignites have high levels of alkali and alkaline earth elements that are organically associated. During carbonization and activation, these elements catalyze gasification resulting in improved pore structure in the resulting activated carbon. In bench-scale evaluations of mercury control capabilities in a low-acid flue gas stream, the North Dakota lignite-derived activated carbon performed as well as the DARCO FGD both as a long-term sorbent and as an elemental mercury oxidant. This means that sorbents from North Dakota lignite could compete in the market for carbon sorbent injection technology, the most mature technology for mercury control from coal-fired power plants, from which the U.S. Environmental Protection Agency (EPA) has mandated a reduction of mercury emissions.

On March 15, 2005, the EPA issued a federal rule to cap and reduce mercury emissions from coal-fired power plants permanently (3). The rule is a market-based cap-and-trade program (Section 111 of the Clean Air Act) and is similar to the program in place for $\mathrm{SO}_{2}$. The rule is to be administered in two phases. The first phase places a cap of 38 tons of mercury beginning in 2010. The second phase sets a final cap of 15 tons by 2018. Currently, the estimate of total mercury emitted from coal-fired power plants is 48 tons; therefore, the reduction is $21 \%$ and $69 \%$, respectively.

With the implementation of the Clear Air Interstate Rule (CAIR) (4), to reduce emissions of $\mathrm{SO}_{2}$ and $\mathrm{NO}_{\mathrm{x}}$ in the eastern 28 states, it is expected that the initial phase of CAIR will partially meet the mercury emission reductions required via cobenefit expected from the additional wet scrubbers and selective catalytic reduction (SCR) systems that will be installed. However, a cap of 15 tons will require additional mercury-specific controls at many power plants. Also, states are moving forward separately and, in several cases, with more stringent mercury emission reductions and earlier timetables than federal standards. 
For trading purposes, the EPA has established allocations for each state, the District of Columbia, and Indian reservations based on their share of the total heat input from coal. These were then adjusted to reflect coal rank and existing air pollution control equipment. For allocation purposes, coals were subcategorized as bituminous, subbituminous, lignite, integrated gasification combined cycle (IGCC), and coal refuse. The total 2010-2017 state allocation is 38 tons and in 2018 and thereafter, 15 tons. Each state will be free to decide if it wishes to participate in the trading program.

In addition to the cap-and-trade program, new coal-fired sources will have additional mercury requirements as part of the New Source Performance Standards (5). The requirements have been subcategorized as follows:

- Bituminous units $-21 \times 10^{-6} \mathrm{lb} / \mathrm{MWh}$

- Subbituminous units

- Wet FGD - $42 \times 10^{-6} \mathrm{lb} / \mathrm{MWh}$

- Dry FGD - $78 \times 10^{-6} \mathrm{lb} / \mathrm{MWh}$

- Lignite units $-145 \times 10^{-6} \mathrm{lb} / \mathrm{MWh}$

- IGCC units $-20 \times 10^{-6} \mathrm{lb} / \mathrm{MWh}$

- Coal refuse units $-1.4 \times 10^{-6} \mathrm{lb} / \mathrm{MWh}$

Specific to North Dakota, the 2010 cap will be 1.564 tons and 0.617 tons beginning in 2018 (6). These caps include the current coal-fired utilities as well as any new units that may be installed during this time frame. The North Dakota lignite industry has been proactive in helping to developing new mercury control technologies in preparation for these regulations. Tests are currently under way at several North Dakota power plants by the EERC, Babcock \& Wilcox, and URS, with support from industry, the North Dakota Industrial Commission (NDIC), the Electric Power Research Institute (EPRI), and the U.S. Department of Energy (DOE).

The projected annual cost for activated carbon sorption of mercury in a duct injection system is significant. For an untreated activated carbon, the carbon-to-mercury weight ratios of 3000-18,000 (gram of carbon injected per gram of mercury in flue gas) have been estimated to achieve $90 \%$ mercury removal from a coal combustion flue gas containing $10 \mu \mathrm{g} / \mathrm{Nm}^{3}$ of mercury (7). More efficient carbon-based sorbents enhanced for mercury control could enable lower carbon-to-mercury weight ratios to be used, thus reducing the operating costs of carbon injection. The United States has about $320 \mathrm{GWe}$ of coal-fired capacity. It is estimated that with the more efficient carbons, carbon injection-to-mercury removal rates of 500:1-1000:1 can be achieved. The potential sorbent cost is estimated to be $\$ 0.30-0.50 / \mathrm{lb}$ for the untreated sorbent and $\$ 0.5$ to $0.8 / \mathrm{lb}$ for the enhanced sorbent. Based on these estimates, the potential market for carbon-based sorbents for mercury control is expected to be upwards of $\$ 100$ million annually.

Current production and use of activated carbon is illustrated in Figure 1. Activated carbon can be produced from a wide range of raw materials that includes coal, wood, and biomass materials. These materials are heat-treated with steam to produce activated carbon. The carbons that are currently used include powdered and granular carbons. These components are used to remove contaminants from liquid- and gas-phase streams. The spent carbons are either disposed of or regenerated. 


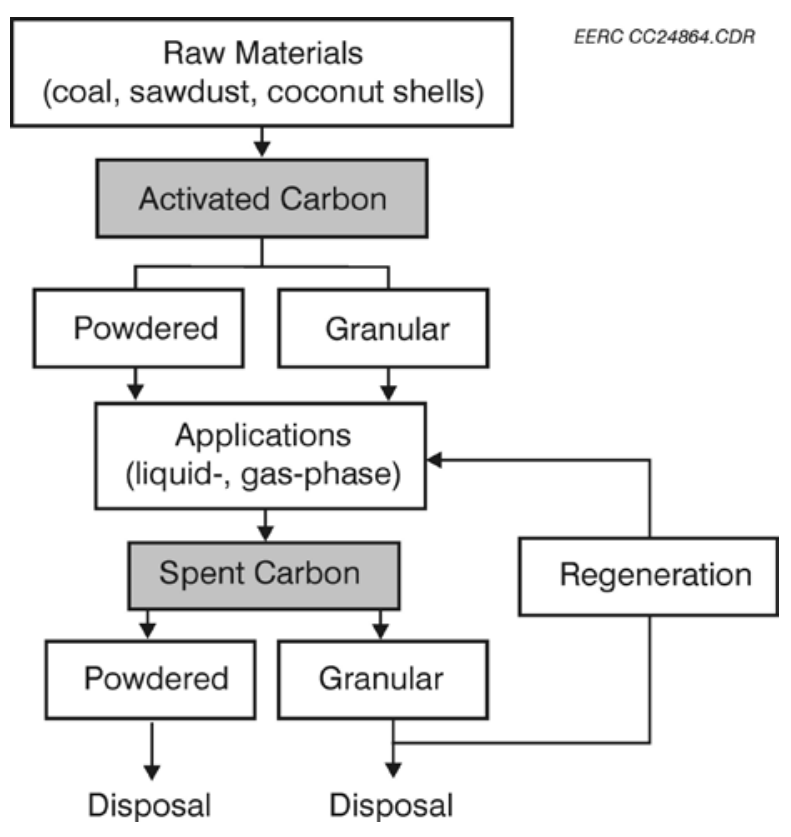

Figure 1. Flow diagram of the current production and use of activated carbon.

The growth in the demand for activated carbon is shown in Figure 2. A significant increase was projected for 2006, not including any of the carbon used for mercury control. The market opportunity for the use of activated carbon for mercury control is the $315 \mathrm{GWe}$ of coal-fired power plant capacity in the United States. The mercury emissions reduction anticipated as a result of the EPA rule is a reduction from 48 tons to 38 tons by 2010 . An estimated $30 \%$ of coalfired power plants will use activated carbon injection for mercury. Based on the expected amounts of activated carbon required for mercury reduction, the authors of this report estimated the market size for activated carbon for mercury control to be about 150,000 tpy. This is compared with the current U.S. consumption of activated carbon for other applications at 225,000 tpy, suggesting a significant increase in the demand for the activated carbon industry.

The production of activated carbon has several synergistic elements with the production of power from coal. The synergies can lead to significantly lower activated carbon production costs as well as potentially improve power plant operation, such as improving operability in the case of a cyclone-fired boiler by using char as fuel and/or reduced $\mathrm{NO}_{\mathrm{x}}$ or by using char and/or offgases as a reburn fuel. The exact choice of the method of char production and char activation will depend upon the degree of integration with the power plant that balances the benefits and minimizes the complexities and risks during operation.

Previous investigations examined the ability to produce activated carbons from four Fort Union lignites for use as mercury sorbents (2). Activated carbons were prepared from relatively high-sodium (4-9 wt\% $\mathrm{Na}_{2} \mathrm{O}$ on an ash basis) lignites because the high sodium contents catalyze the gasification reactions producing a highly porous activated carbon. The activated carbons were produced by carbonization at $400^{\circ} \mathrm{C}\left(752^{\circ} \mathrm{F}\right)$ in nitrogen followed by steam activation at $750^{\circ} \mathrm{C}\left(1382^{\circ} \mathrm{F}\right)$ and $800^{\circ} \mathrm{C}\left(1472^{\circ} \mathrm{F}\right)$ in nitrogen. Iodine numbers 


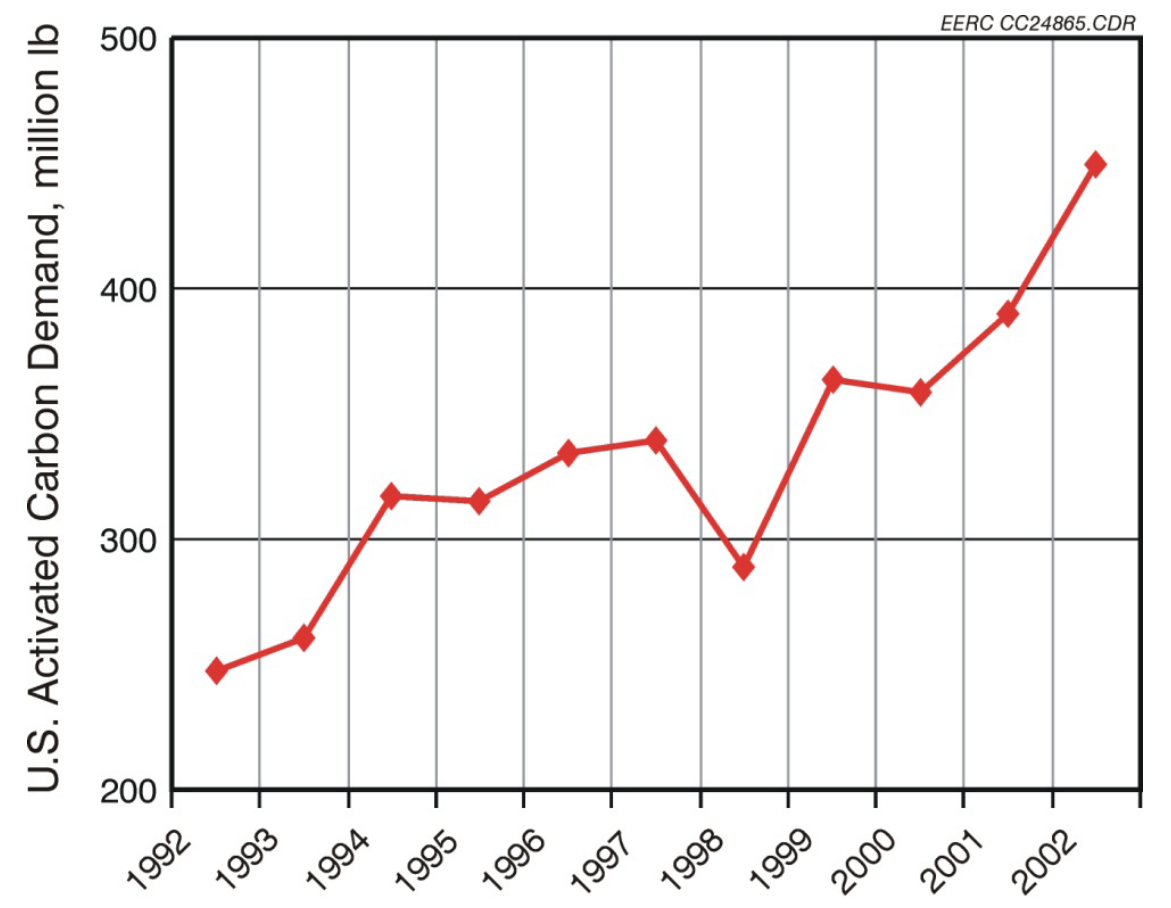

Figure 2. Demand for activated carbon in the United States.

(mg I $\mathrm{I}_{2} \mathrm{~g}$ sorbent) for the lignite-based activated carbons ranged from 320 to 440 as compared to 524 for the DARCO FGD.

The lignite-based activated carbons, were tested in a thin-film, fixed-bed, bench-scale reactor using a simulated lignitic flue gas consisting of nominally $10 \mu \mathrm{g} / \mathrm{Nm}^{3} \mathrm{Hg}^{0}, 6 \% \mathrm{O}_{2}$, $12 \% \mathrm{CO}_{2}, 15 \% \mathrm{H}_{2} \mathrm{O}, 580 \mathrm{ppm} \mathrm{SO}_{2}, 120 \mathrm{ppm} \mathrm{NO}, 6 \mathrm{ppm} \mathrm{NO}$, and $1 \mathrm{ppm} \mathrm{HCl}$ in $\mathrm{N}_{2}$. All of the lignite-based activated $\left(750^{\circ} \mathrm{C}, 1382^{\circ} \mathrm{F}\right)$ carbons required a 30 - to 45 -minute conditioning period in the simulated lignite flue gas before they exhibited good mercury sorption capacities and $\mathrm{Hg}^{0}$ oxidation potentials $\left(>90 \% \mathrm{Hg}^{2+}\right)$.

The Fort Union lignite activated carbon $\left(800^{\circ} \mathrm{C}, 1472^{\circ} \mathrm{F}\right)$ and DARCO FGD were selected for additional testing in a 580-MJ/hr (550,000-Btu/hr) pulverized coal-fired unit based on the sorbent screening results (reactivity and capacity), physical properties (particle size and surface area), and cost (2). The Fort Union lignite activated carbon, activated at $800^{\circ} \mathrm{C}\left(1472^{\circ} \mathrm{F}\right)$, and DARCO FGD were effective in capturing mercury.

\section{GOAL AND OBJECTIVES}

The goal of this EERC project was to develop information to determine the feasibility of a commercial process for carbon production from North Dakota lignite. This would be the basic carbon that can be improved by sorbent-enhancement agents or by chemically treating the carbon prior to injection. The objectives of the project included the following: 
1. Examine viable options for producing activated carbon sorbents from lignite.

2. Scale up the carbon activation process of Fort Union lignite coals from laboratory fixed-bed to pilot-scale production.

3. Determine the surface area, physiochemical surface characteristics, and flue gassurface interactions of prepared carbons and compare to bench-scale and other carbons.

4. Develop a conceptual design for commercial implementation of an activated carbon production facility in North Dakota.

In order to meet these objectives, researchers produced activated carbon in the pilot-scale reactors, examined chemical and physical characteristics of the prepared carbons, assessed the potential mercury sorbent and activated carbon markets, and prepared a conceptual design for a commercial activated carbon plant.

The research was carried out in three tasks.

\section{Task 1 - Pilot-Scale Optimization and Production}

This task assessed the application of various methods to produce activated carbons. Activated carbon production involved two main steps: 1) carbonization-driving out volatiles to obtain the fixed-carbon portion of the coal and 2) activation-partial gasification with steam or carbon dioxide to open the pore structure and create the surface area. The two main subtasks were optimization of activated carbon production and pilot-scale testing for mercury capture.

\section{Task 2 - Sorbent Property Investigation}

The main objective of this task was to understand the properties of carbon sorbents from North Dakota lignite prepared under various applications. Under this task, physical and chemical characteristics of the produced activated carbons were examined.

\section{Task 3 - Conceptual Design of a Commercial Plant Producing Activated Carbon from Fort Union Lignite}

The activities of this task included both a market assessment and preparation of a conceptual design. The market assessment process included the following activities:

- Industry structure and market

- Competitive analysis

- Market opportunities and challenges

- Supply and demand

- Recommendations for marketing strategies 
The final activity under this task was to use test results from Tasks 1 and 2 to prepare a design and economics of a commercial plant located within North Dakota to produce activated carbon from North Dakota lignite.

\section{EXPERIMENTAL}

\section{Task 1 - Pilot-Scale Optimization and Production}

Optimization and production of activated carbon were conducted in both bench-scale and pilot-scale systems. The bench-scale reactors are vertically oriented fixed-bed tube furnace reactors for batch preparation of sample. The rotary kiln tube furnace oriented horizontally is used for pilot-scale optimization and production in a continuously mode. A short description of both char and activated carbon production procedure is also described here.

\section{Bench-Scale Reactor}

Two laboratory-scale reactors were used to produce activated carbon in small quantities for quick and easy evaluation of the produced char and activated carbon so that optimum conditions for pilot-scale system could be determined. Char and activated carbons were prepared by using stainless steel reactors with either a 1-in.-i.d. tube 18 in. long or a 2.5 -in.-i.d. tube approximately 36 in. long.

\section{Pilot-Scale Rotary Kiln}

A used Harper International rotary kiln became the center of the rotary kiln system used for pilot-scale optimization and production. The kiln is a sealed, indirectly electrically heated rotary kiln with a nominal heated zone 6 in. in diameter and 5 feet long, 3-zone temperature control to $1000^{\circ} \mathrm{C}$, inert atmosphere operating conditions, rotation from 1 to $5 \mathrm{rpm}$, internal screw-fed auger, and variable inclination to $5^{\circ}$. The residence time of solids inside the kiln system is determined by a combination of tube rotational speed and tube inclination. The equipment is in turnkey operational condition. The project team designed the emission-handling back end of the system. Figure 3 shows the schematic of the rotary kiln reactor system, and Figure 4 shows the rotary kiln system installed in the EERC pilot plant area.

Modifications to the 6-in. rotary kiln were completed as an on-demand basis. The gashandling system runs countercurrent to the coal feed through the kiln. Lifters were added to the tube interior to improve mixing and gas-solids contact time. New solid lifters made of stainless steel with $1 / 4$-in circular perforation were also added in the heated section of the rotary kiln. Old solid lifters made of stainless steel with 3/4-in. $\times 3 / 8$-in. parallelogram-shaped perforation had collapsed after long-term exposure to high temperatures. The new lifters worked better than the old lifters. The feeders were calibrated with $-1 / 4$-in. +10 -mesh and $-1 / 8$-in. +10 -mesh coal fractions of Hagel Center lignite acquired under a previous project. Terminal velocity 




Figure 3. Schematic of the rotary kiln reactor system.

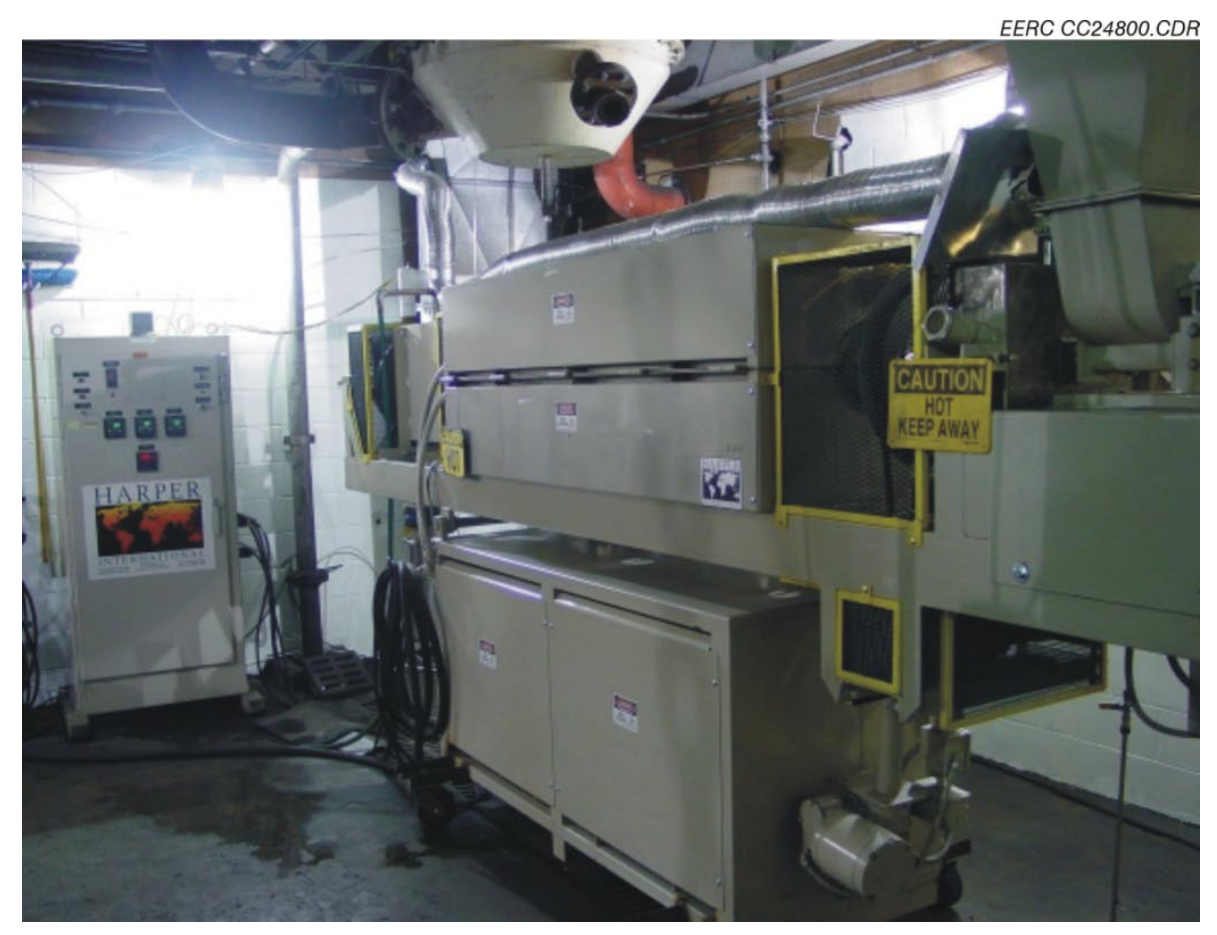

Figure 4. The rotary kiln reactor system installed in the EERC pilot plant. 
calculations to estimate lower-end particle size were performed. Smaller-sized particles could be fed; however, feeding, handling, and dustiness may produce problems. There will presumably be degradation, especially if multiple passes are required to obtain proper residence time and conversion. Further modifications of the 6-in.-scale rotary kiln were carried out based on the experience obtained during operation. Condensation of steam occurred during steam activation of the carbonized char, which resulted in wet product. The condensation of steam in the collection pot was significant when higher flow rates of steam (4-6 lb/hr water equivalent) were used to activate the carbonized char. To eliminate the steam condensation, insulation was added to the discharge end of the kiln. With the new insulation, steam condensation was successfully eliminated during steam activation.

The steam generation system was upgraded with the procurement of a Sussman MBA6 electric steam generator from Sussman Electric Boilers, Long Island City, New York. The steam generator is rated to produce $18 \mathrm{lb} / \mathrm{hr}$ of steam, with a design pressure of 100 psig and maximum working pressure of 85 psig. Integration of the steam generation system with the rotary kiln system was completed. To superheat the steam generated by the steam generation system, we installed a 3-in.-o.d. tube furnace, which has a coil-type heat exchanger. We successfully integrated the tube furnace system with the steam generation system.

The auxiliary gas analyzer system used during steam activation of the char was also modified. The gas analyzer is designed to accept gas with low or no sulfur. To remove $\mathrm{SO}_{2}$ from the gas stream, a canister with $\mathrm{SO}_{2}$ sorbent was added in the gas analyzer system.

\section{Block Diagram}

A simple block diagram showing the carbonization and activation steps along with process operating conditions for producing activated carbon is in Figure 5. The carbonization process produces char from raw coal, and the activation process produces activated carbon from char made in the carbonization process. Char is an intermediate product, which is used as feed material for producing activated carbon. Activated carbon is the final product.

EERC CC31626.CDR

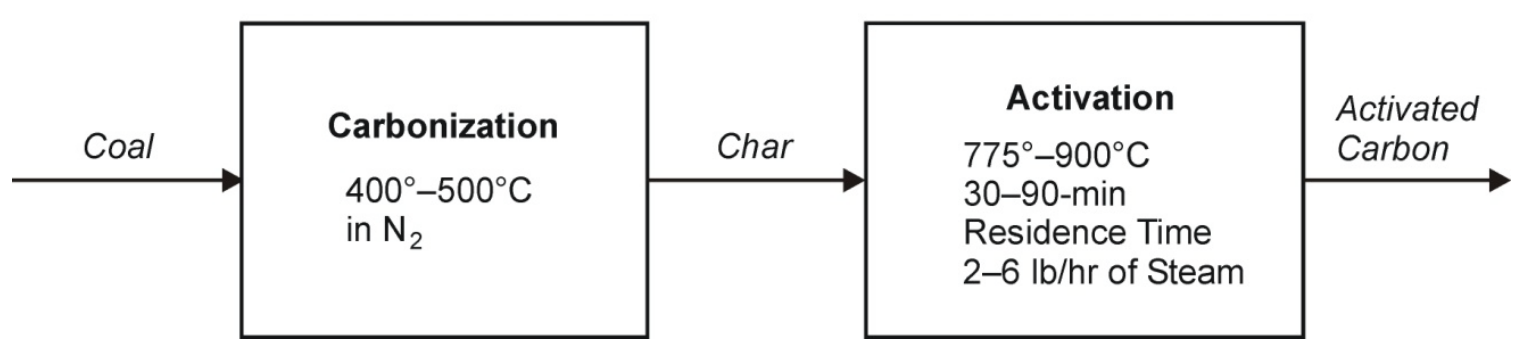

Figure 5. Block diagram of activated carbon production from coal. 


\section{Preparation of Chars}

Lignite coals from the Center Mine were pyrolyzed in $\mathrm{N}_{2}$ to remove moisture and volatile matter and to increase the surface area of the material, creating mesopores that are thought to facilitate the heterogeneous $\mathrm{Hg}-\mathrm{C}$ reaction. The process is known as the carbonization process.

Carbonization was conducted in batch mode in a fixed-bed stainless steel tube reactor (3-in. diameter). For carbonization, around $935 \mathrm{~g}$ of the granular coal $(-1 / 8+20$-mesh) was placed in the bench-scale reactor. The tube reactor was placed in a vertical furnace. The stainless steel tube was attached to a nitrogen inlet tube. The reactor was heated to desired temperature $\left(400^{\circ}-600^{\circ} \mathrm{C}\right)$ in a gentle flow of nitrogen. The reactor was held at this temperature until tarry material ceased to evolve. The char that was produced was stored under nitrogen for further use.

Carbonization was carried out on a continuous basis in the pilot-scale rotary kiln. A 15-lb batch of coal $(-1 / 8+20$ mesh) was fed into the feed hopper, which was purged in a gentle flow of nitrogen. Once the feeder was empty, another batch of $15 \mathrm{lb}$ of coal was fed into the feed hopper. This kind of operation during carbonization increased the char production rate and reduced labor hours and other operating expenses needed per $\mathrm{lb}$ of carbonized char produced. The rotary kiln was set to the desired temperature $\left(425^{\circ}-600^{\circ} \mathrm{C}\right)$. The carbonization of coal was conducted in a nitrogen atmosphere. Coal was fed with a K-Tron dual-screw feeder in the feed end of the kiln. The residence time of coal in the heated section of the rotary was set at $60 \mathrm{~min}$ with a combination of rotary tube slope $\left(1^{\circ}\right)$ and rotational speed (2 rpm.). The carbonization step drove out moisture and volatile materials from the coal structure, leading to the formation of char, which was collected in the discharged end of the rotary kiln and stored under nitrogen.

\section{Preparation of Activated Carbons}

Activated carbons were prepared by steam activation of char made from Center lignite coal. Steam activation enhances the minimal pore structure created during the initial carbonization where volatile matter is released. The diameters of the pores are enlarged and thus pore volume is increased. The development of new porosity in the form of micropores during steam activation results from the removal of less crystalline carbon by reaction with the steam to form $\mathrm{CO}$ and $\mathrm{H}_{2}$ and some thermal rearrangement of the structures to form more graphene sheets. This burnout of the disordered structure may be catalyzed by the inorganic material, especially the alkali present.

Steam activation was conducted in batch mode in the 3-in. fixed-bed vertical stainless steel tube reactor used for pyrolysis. Char was paced in the tube reactor, which was heated to the desired temperature in a gentle flow of nitrogen $\left(250 \mathrm{~cm}^{3} / \mathrm{min}\right)$. At this stage, steam was introduced from the bottom of the reactor. The char was then heated in a gentle flow of steam (7-8 $\mathrm{g} / \mathrm{min}$ ) and nitrogen for the desired time period. At the end of the activation, the steam was stopped and the reactor was cooled to room temperature in flowing nitrogen. The activated carbon was removed from the reactor, weighed, and stored under nitrogen for further use.

Steam activation of char was conducted on a continuous basis in the pilot-scale rotary kiln. Char was placed in the feed hopper, which was purged with a gentle flow of nitrogen. The 
temperature of the heated section of the rotary kiln was set to the desired temperature $\left(775^{\circ}-900^{\circ} \mathrm{C}\right)$. Char was fed with a K-Tron dual-screw feeder in the feed end of the kiln. The residence time of char in the heated section of the rotary was set at 30 to 90 min with a combination of rotary tube slope and rotational speed. Steam (4-6 lb/hr) generated by a Sussman MBA6 electric steam generator and superheated $\left(300^{\circ}-350^{\circ} \mathrm{C}\right.$ ) by a 3-in.-o.d. tube furnace was fed to the discharge end of the rotary kiln. Thus a countercurrent char and steam flow was established in the rotary kiln tube furnace. Partial gasification of char by steam at high temperature produced micropores in the char, resulting high surface area activated carbon.

\section{Task 2 - Sorbent Property Investigation}

The iodine number, a measure of surface area, of char and activated carbon was determined using ASTM Standard Test Method D 4607. The activated carbon was also treated using various methods for testing the mercury capture capability of activated carbon in a benchscale system. Mercury capture tests were carried out in a bench-scale system using the sorbents produced in bench- and pilot-scale systems. The activated carbon produced at different operating conditions in the pilot-scale rotary kiln system was also tested for mercury capture at the EERC pilot-scale combustors such as the particulate test combustor (PTC) and the combustion test facility (CTF).

\section{Determination of Iodine Numbers}

The surface area of the chars and activated carbons was determined by iodine numbers that were determined to investigate the effect of conditions used for generating the activated carbons on the surface area of the carbons. To determine iodine numbers, carbons were ground to pass through a 200-mesh sieve. Surface areas (iodine number) were determined using the ASTM D 4607 method.

\section{Preparation of Water-Washed Carbons}

The treatment with water was carried out to determine whether the removal of ash from the activated carbon improves mercury capture. Activated carbons were ground to pass through a 325-mesh sieve. Once ground, the carbon was added to a conical flask containing $100 \mathrm{~cm}^{3}$ water. The slurry was stirred for 3 hours and was then filtered, washed with water, and dried at $110^{\circ} \mathrm{C}$.

\section{Preparation of HCl-Washed Carbons}

Activated carbons were ground to pass through a 325-mesh sieve and added to an aqueous solution of hydrochloric acid $(0.1 \mathrm{~N})$ in a conical flask. The slurry was stirred for 3 hours, then filtered, washed with water, and dried at $110^{\circ} \mathrm{C}$.

\section{Preparation of HCl-Impregnated Carbons}

Activated carbons were ground to pass through a 325-mesh sieve. Five g of an aqueous solution containing $50 \mathrm{ppm}$ hydrochloric acid was slowly added to $5 \mathrm{~g}$ of activated carbon with stirring. The resulting paste was air-dried, followed by drying at $110^{\circ} \mathrm{C}$. Carbons containing 
0.5 and $1 \%$ hydrochloric acid were also prepared using the impregnation technique described above.

\section{Bench-Scale Mercury Test System}

A 63.5-mm-diameter holder supports a 150-mg fixed bed of sorbent on a quartz tissue filter; the sorbent under evaluation is vacuum deposited onto this support. The fixed bed and all associated plumbing are held within a temperature-controlled oven at a nominal $135^{\circ} \mathrm{C}\left(275^{\circ} \mathrm{F}\right)$. Flue gas is supplied to the fixed bed via a manifold that combines gases, water, and either $\mathrm{Hg}^{0}$ or $\mathrm{HgCl}_{2}$ from permeation sources. These permeation sources (VICI Metronics) are kept under constant temperature and flow conditions. Equipment in current use on the bench-scale flue simulator includes a PSA conditioning and conversion unit and a PSA Sir Galahad online mercury analyzer. This analyzer is capable of detecting mercury at levels around $10 \mathrm{ng} / \mathrm{m}^{3}$ and uses a gold trap to separate $\mathrm{Hg}^{0}$ from the sample stream, allowing the analysis method (atomic fluorescence spectrometry) to take place in an inert gas.

\section{Particulate Test Combustor (PTC)}

A 550,000-Btu/hr pc-fired unit, known as the PTC, was used to test the mercury capture capability of activated carbon produced in a rotary kiln. Figure 6 shows the schematic diagram of the system. Activated carbon was fed with a K-Tron dual-screw feeder upstream of the ESP. The feeder was calibrated prior to the start of carbon injection. In addition, the weight of carbon added during a run was divided by the time of injection to provide an average feed rate. According to the calibration data and weight-of-added-carbon data, the feeder appeared to provide a very steady and consistent feed rate within a few percentage points of the target rate.

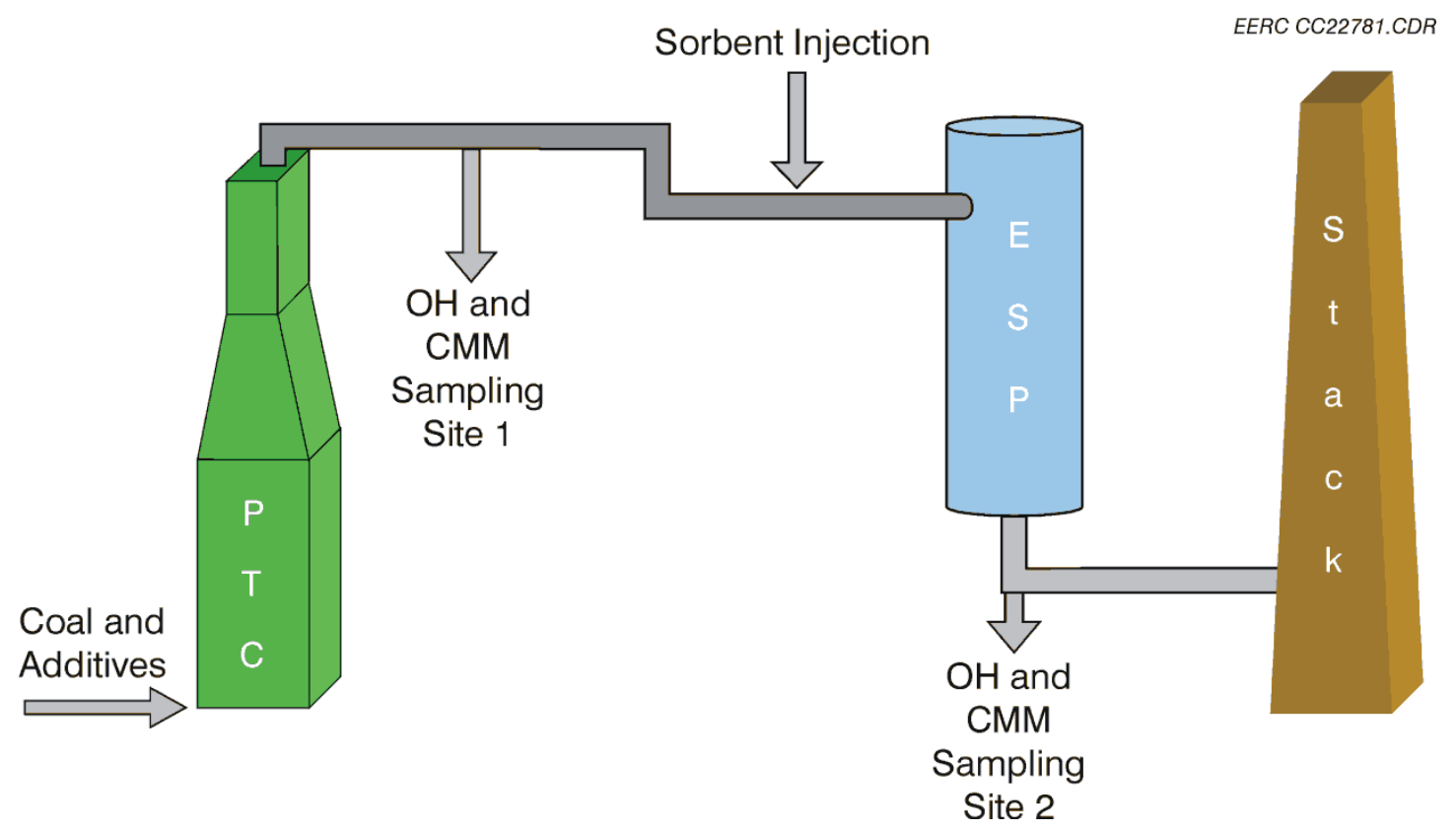

Figure 6. Injection and sampling schematic of the PTC with an ESP. 
The carbon feed and injection system worked very well, and there were no problems with inconsistent feeding or plugging of the feeder or injection system.

Continuous mercury monitors (CMMs) were used to monitor mercury vapor concentrations at the ESP inlet (Site 1) and outlet (Site 2) for the entire testing period.

\section{Combustion Test Facility (CTF)}

An isometric drawing of the EERC CTF is shown in Figure 7. The furnace capacity is approximately $100 \mathrm{lb} / \mathrm{hr}$ (750,000 Btu/hr) of a moderately high-Btu-content biomass fuel, and for combustion testing of fuels of all rank. The furnace can be configured in many different arrangements, and the graphic shows a second probe bank used for low-temperature ash-fouling evaluations. This section was replaced by a series of water-cooled, refractory-lined heat exchangers for the tests reported here.

When firing solid fuels, the fuel is normally pulverized remotely in a hammer mill pulverizer, targeted to a size of $70 \%$ less than 200 mesh. It is then charged to a microprocessorcontrolled weight loss feeder from a transport hopper. Combustion air is preheated by an electric air heater. The pulverized fuel is screw-fed by the gravimetric feeder into the throat of a venturi section in the primary air line to the burner. Heated secondary air is introduced through an adjustable swirl burner, which uses only primary and secondary air. Flue gas passes out of the furnace into a 10-inch-square duct that is also refractory-lined. Located in the duct is a vertical

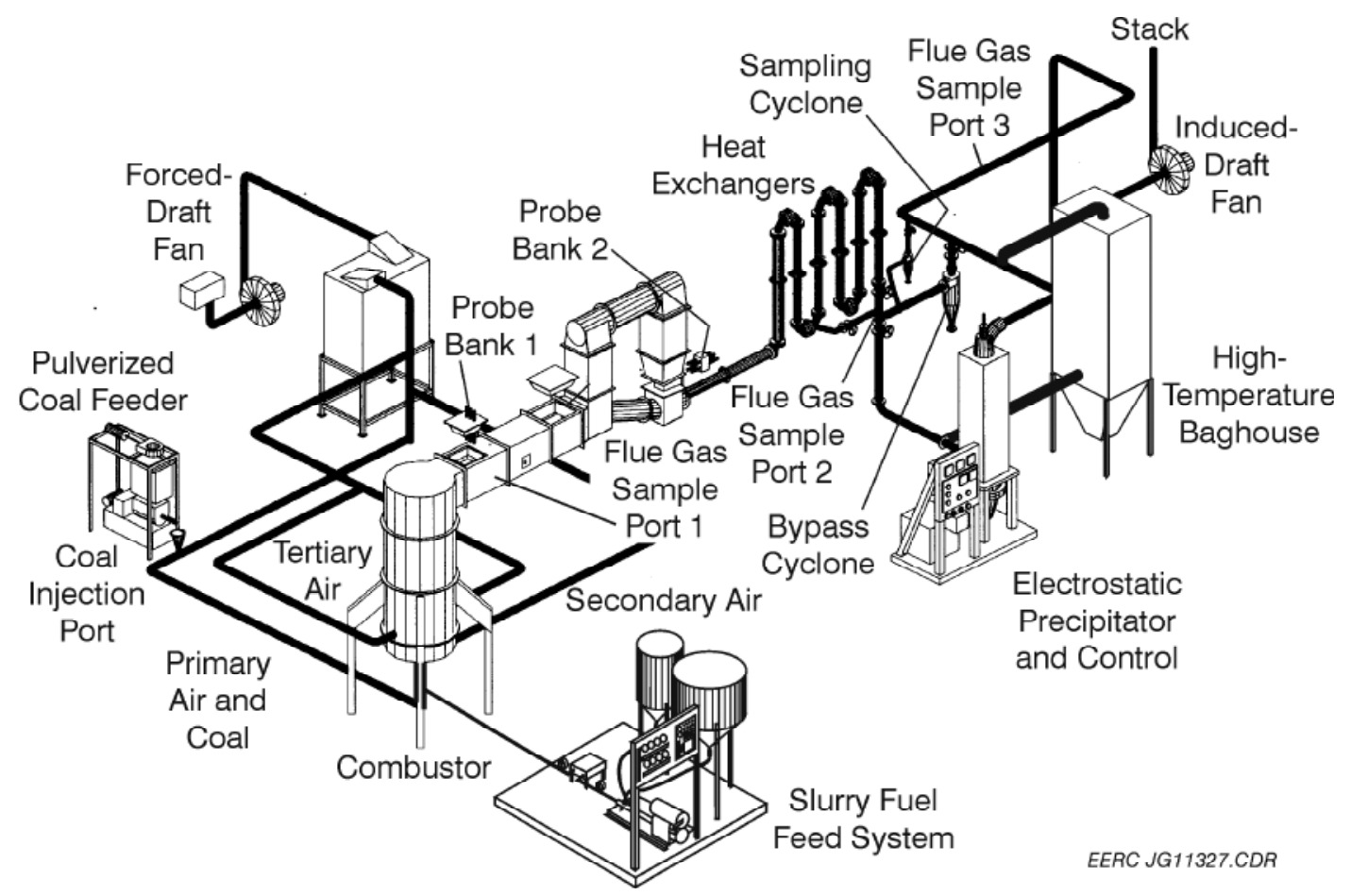

Figure 7. CTF and auxiliary systems. 
probe bank designed to simulate superheater surfaces in a commercial boiler. After leaving the probe duct, the flue gas passes through a series of water-cooled, refractory-lined heat exchangers and a series of air-cooled heat exchangers before being discharged through either an ESP or a baghouse.

An ESP was used for the tests performed for mercury capture capability of activated carbon produced in rotary kiln. Activated carbon was fed with a K-Tron dual-screw feeder upstream of the ESP. The feeder was calibrated prior to the start of carbon injection. The carbon feed and injection system worked very well, and there were no problems with inconsistent feeding or plugging of the feeder or injection system. CMMs were used to monitor mercury vapor concentrations at the ESP inlet and outlet for the entire testing period.

\section{Task 3 - Conceptual Design of a Commercial Plant Producing Activated Carbon from Fort Union Lignite}

A subcontract was executed with Chavond-Barry Engineering Corporation to prepare a conceptual design for an activated carbon plant attached to a power generation facility as part of the "Activated Carbon Production from North Dakota Lignite" project. The market assessment process was also conducted, including industry structure and market, competitive analysis, market opportunities and challenges, supply and demand, and recommendations for marketing strategies.

\section{RESULTS AND DISCUSSION}

\section{Task 1 - Pilot-Scale Optimization and Production}

Optimization and production of activated carbon were carried out in both bench-scale and pilot-scale systems. The bench-scale tests helped to identify potential optimum conditions for pilot-scale optimization and production. In this section, bench-scale test results are described first, followed by pilot-scale optimization and production.

\section{Bench-Scale Optimization and Production}

As a prelude to laboratory-scale fixed-bed and bench-scale rotary kiln tests, two 5-gal pails of the Hagel A seam coal from the Center Mine were received from BNI Coal, Ltd., on July 28, 2005. The coal was sized to $-1 / 4+1 / 8$ and $-1 / 8+20$ mesh and stored in nitrogen in the freezer. The results of the proximate, ultimate, and bulk chemistry analysis performed on the sample are presented in Table 1 . About $1 \mathrm{~kg}$ of the smaller size fraction was sent to a kiln vendor for preliminary testing in late August.

A laboratory-scale test matrix, presented in Table 2, was developed to evaluate the effects of activation conditions on the activated carbon produced from Center lignite. The effect of steam activation operational parameters (temperature $\left[750^{\circ}-900^{\circ} \mathrm{C}\right]$ and reaction time [30$60 \mathrm{~min}]$ ) and char preparation on the burnout rate and surface area of the resulting activated 
Table 1. Coal Analysis of Hagel A Center Lignite, received July 28, 2005

\begin{tabular}{|c|c|c|}
\hline Proximate Analysis, wt\% & As-Sampled & Moisture-Free \\
\hline Moisture Content & 30.69 & NA* \\
\hline Volatile Matter & 30.24 & 49.26 \\
\hline Fixed Carbon & 25.47 & 41.48 \\
\hline Ash & 5.69 & 9.26 \\
\hline \multicolumn{3}{|l|}{ Ultimate Analysis, wt\% } \\
\hline Hydrogen & 7.03 & 4.46 \\
\hline Carbon & 39.5 & 64.34 \\
\hline Nitrogen & 0.76 & 1.24 \\
\hline Sulfur & 0.8 & 1.31 \\
\hline Oxygen & 46.22 & 19.39 \\
\hline Ash & 5.69 & 9.26 \\
\hline \multicolumn{3}{|l|}{ Ash Analysis, wt\% } \\
\hline $\mathrm{SiO}_{2}$ & & 23.80 \\
\hline $\mathrm{Al}_{2} \mathrm{O}_{3}$ & & 13.50 \\
\hline $\mathrm{Fe}_{2} \mathrm{O}_{3}$ & & 9.52 \\
\hline $\mathrm{TiO}_{2}$ & & 0.48 \\
\hline $\mathrm{P}_{2} \mathrm{O}_{5}$ & & 0.15 \\
\hline $\mathrm{CaO}$ & & 17.60 \\
\hline $\mathrm{MgO}$ & & 6.22 \\
\hline $\mathrm{Na}_{2} \mathrm{O}$ & & 8.04 \\
\hline $\mathrm{K}_{2} \mathrm{O}$ & & 0.48 \\
\hline $\mathrm{SO}_{3}$ & & 18.91 \\
\hline $\mathrm{BaO}$ & & 0.75 \\
\hline $\mathrm{SrO}$ & & 0.58 \\
\hline
\end{tabular}

* Not applicable.

carbon were examined. These bench-scale experiments under controlled temperature, reaction time, and steam rate were preliminary to pilot-scale steam activations in a rotary kiln where control of conditions is more difficult. The relationships developed in this portion of the project were intended to guide further development at the pilot scale.

The carbon yields for the series of steam activations performed with the Center coal at various bed temperatures for different time with char produced in the large reactor tube are reported in Table 2 . The burnout rate is the percentage difference between the initial char weight and the product carbon as determined by the equation: $100 \times(1-$ [carbon wt/char wt] $)$. The effect of bed temperature on burnout was shown to be linearly proportional $\left(R^{2}=0.93\right)$ over the temperature range employed $\left(750^{\circ}\right.$ to $900^{\circ} \mathrm{C}$ ) (Figure 8). The linearity with respect to temperature was somewhat surprising given the wide variety of disordered structures and possible pore structures. In fact, we did not see this linear relationship with other coals in previous studies.

The surface area as represented by the iodine number also linearly increased over the temperature range studied $\left(\mathrm{R}^{2}=0.94\right)$ (Figure 8 ). This is consistent with the linear relationship between burnout and temperature. As long as the burnout remains below 50\%, we expect to see 
Table 2. Test Matrix for Fixed-Bed Optimization of Center Lignite, $-1 / 8$-in. + 20-mesh Particle-Size Fraction

\begin{tabular}{|c|c|c|c|c|}
\hline Starting Material & Initial Mass, g & Activation Conditions & \% Yield & $\begin{array}{c}\text { Iodine No., } \\
\mathrm{mg} \mathrm{I}_{2} / \mathrm{g}\end{array}$ \\
\hline Center Coal $^{1}$ & 1028.1 & Carbonized at $400^{\circ} \mathrm{C}$ & 44.3 & 190 \\
\hline Center Coal Char & 70.5 & $\begin{array}{l}\text { Steam activation at } 750^{\circ} \mathrm{C} \text { for } \\
30 \mathrm{~min}\end{array}$ & 69.8 & 318 \\
\hline Center Coal Char & 75.5 & $\begin{array}{l}\text { Steam activation at } 800^{\circ} \mathrm{C} \text { for } \\
30 \mathrm{~min}\end{array}$ & 65.0 & 348 \\
\hline Center Coal Char & 87.0 & $\begin{array}{l}\text { Steam activation at } 850^{\circ} \mathrm{C} \text { for } \\
30 \mathrm{~min}\end{array}$ & 63.1 & 398 \\
\hline Center Coal Char & 80.0 & $\begin{array}{l}\text { Steam activation at } 850^{\circ} \mathrm{C} \text { for } \\
60 \mathrm{~min}\end{array}$ & 60.0 & 408 \\
\hline Center Coal Char & 84.6 & $\begin{array}{l}\text { Steam activation at } 900^{\circ} \mathrm{C} \text { for } \\
30 \mathrm{~min}\end{array}$ & 54.5 & 490 \\
\hline Center Coal Char & 84.6 & $\begin{array}{l}\text { Steam activation at } 900^{\circ} \mathrm{C} \text { for } \\
60 \mathrm{~min}\end{array}$ & 48.8 & 460 \\
\hline Center Coal & 135.3 & Carbonized at $400^{\circ} \mathrm{C}$ & 47.0 & $\mathrm{ND}^{2}$ \\
\hline Center Coal Char ${ }^{3}$ & 63.6 & $\begin{array}{l}\text { Steam activation at } 850^{\circ} \mathrm{C} \text { for } \\
30 \mathrm{~min}\end{array}$ & 69.3 & 401 \\
\hline Center Coal $^{4}$ & 3461.5 & Carbonized at $400^{\circ} \mathrm{C}$ & 60.0 & 212 \\
\hline Center Coal $^{4}$ & 1017.3 & Carbonized at $500^{\circ} \mathrm{C}$ & 44.2 & 268 \\
\hline Center Coal $^{4}$ & 944 & Carbonized at $600^{\circ} \mathrm{C}$ & 42.7 & 290 \\
\hline Center Coal Char ${ }^{5}$ & 102.36 & $\begin{array}{l}\text { Steam activation at } 850^{\circ} \mathrm{C} \text { for } \\
30 \mathrm{~min}\end{array}$ & 81.5 & 460 \\
\hline Center Coal Char ${ }^{5}$ & 106.53 & $\begin{array}{l}\text { Steam activation at } 900^{\circ} \mathrm{C} \text { for } \\
30 \mathrm{~min}\end{array}$ & 76.7 & 520 \\
\hline Center Coal Char ${ }^{5}$ & 105.81 & $\begin{array}{l}\text { Steam activation at } 950^{\circ} \mathrm{C} \text { for } \\
30 \mathrm{~min}\end{array}$ & 70.0 & 651 \\
\hline Center Coal Char ${ }^{6}$ & 104.97 & $\begin{array}{l}\text { Steam activation at } 850^{\circ} \mathrm{C} \text { for } \\
30 \mathrm{~min}\end{array}$ & 79.2 & 422 \\
\hline Center Coal Char ${ }^{6}$ & 104.23 & $\begin{array}{l}\text { Steam activation at } 900^{\circ} \mathrm{C} \text { for } \\
30 \mathrm{~min}\end{array}$ & 74.0 & 495 \\
\hline Center Coal Char ${ }^{6}$ & 103.24 & $\begin{array}{l}\text { Steam activation at } 950^{\circ} \mathrm{C} \text { for } \\
30 \mathrm{~min}\end{array}$ & 71.9 & 620 \\
\hline \multicolumn{5}{|c|}{$\begin{array}{l}{ }^{1} \text { Prepared in the } 3 \text {-in. fixed-bed reactor. } \\
2 \text { Not determined. } \\
{ }^{3} \text { Derived from coal prepared in the } 1 \text {-in. fixed-bed reactor. } \\
{ }^{4} \text { Prepared in the } 3 \text {-in. fixed-bed reactor from coal received on } 6 / 21 / 06 \text {. } \\
{ }^{5} \text { Prepared in the } 1 \text {-in. fixed-bed reactor from char made in } 3 \text {-in. fixed-bed reactor at } 600^{\circ} \mathrm{C} \text {. } \\
{ }^{6} \text { Prepared in the } 1 \text {-in. fixed-bed reactor from char made in 3-in. fixed-bed reactor at } 500^{\circ} \mathrm{C} \text {. }\end{array}$} \\
\hline
\end{tabular}




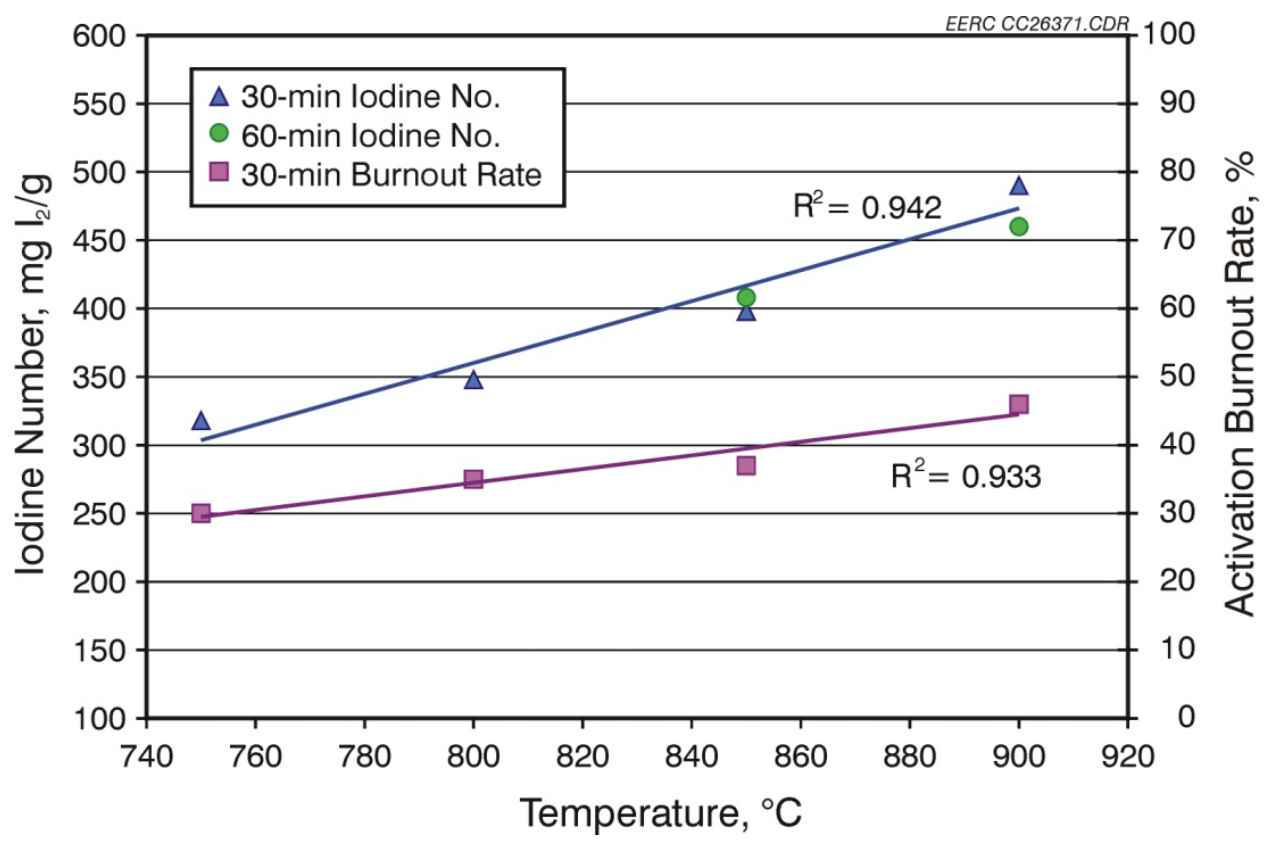

Figure 8. Iodine number and burnout rate of activated carbons prepared from Center lignite in a 1 -in. reactor at various activation temperatures.

development of microporosity with increasing burnout. Previous studies have documented the linear increase in Brunauer-Emmett-Teller (BET) or other surface areas with increasing burnout (8).

For the reaction at $850^{\circ} \mathrm{C}$, the length of the time period for steam activation (30 versus 60 min) had only a very small effect on both burnout and surface area. The longer reaction time (60 min) only increased the burnout from $37 \%$ (for the 30 -min experiment) to $40 \%$ and increased the iodine number from 398 to $408 \mathrm{mg} \mathrm{I}_{2} / \mathrm{g}$. Comparison of the burnout and surface areas of activated carbons produced at a higher temperature $\left(900^{\circ} \mathrm{C}\right)$ for 30 and 60 min gave different results, as expected. The burnout for the 60 -min carbon produced at $900^{\circ} \mathrm{C}$ was $51 \%$, compared to $46 \%$ for the 30 -min carbon at $900^{\circ} \mathrm{C}$. The surface area for the 60 -min carbon was significantly lower (460 $\mathrm{mg} \mathrm{I}_{2} / \mathrm{g}$ ) than that of the 30-min carbon. These results are consistent with the hypothesis that as the burnouts approach $50 \%$, the pore walls begin to burn through and the surface area decreases. The faster gasification rate at $900^{\circ} \mathrm{C}$ produced this effect at the longer reaction time.

The iodine number of char produced at bench-scale reactor at three different temperatures of $400^{\circ}, 500^{\circ}$, and $600^{\circ} \mathrm{C}$ are 212,268 , and $290 \mathrm{mg} \mathrm{I} / \mathrm{g}$ respectively. Higher carbonization temperature produced char with higher iodine number. The iodine number of activated carbon produced at $850^{\circ} \mathrm{C}$ and 30 min of activation from char made at $500^{\circ}$ and $600^{\circ} \mathrm{C}$ are 422 and $460 \mathrm{mg} \mathrm{I} / \mathrm{g}$, respectively. Higher carbonization temperatures helped to produce activated carbon with higher iodine numbers. The iodine number of activated carbon made from the same char also increased with the increase in activation temperature and residence time (Table 2). 
The iodine number of char and activated carbon made in a bench-scale system at different operating conditions proved that higher carbonization temperature, higher activation temperature, and longer residence time is the better operating conditions for producing better activated carbon from Center lignite coal.

\section{Pilot-Scale Optimization and Production}

The pilot-scale optimization and production consisted of shakedown tests and optimization tests conducted for both carbonization and steam activation. The optimization parameters tested for carbonization were three different temperatures $425^{\circ}, 550^{\circ}$, and $600^{\circ} \mathrm{C}$. The optimization parameters tested for steam activation of carbonized char were steam flow rate, activation temperature, and residence time. The shakedown tests and process optimization tests carried out in this project are described below. Carbonization of lignite coal is first described and steam activation of carbonized char is described thereafter.

\section{Carbonization of North Dakota Lignite}

The rotary kiln system was made fully operational by mid-September 2005, and shakedown carbonization tests were begun. After the successful demonstration of shakedown tests, process optimization tests for carbonization were performed. The test matrix for carbonization tests is presented in Table 3.

\section{Test Shakedown}

Shakedown carbonization tests were conducted using Hagel lignite coal from the Center Mine, which was left over from previous pilot-scale combustion test runs. It was obtained from one of the bunkers in fuel storage that was being emptied. The coal was processed to a nominal $-1 / 8$-in. +10 -mesh material.

Table 4 shows the test conditions and resulting iodine numbers for each of the shakedown tests. The system was modified during the shakedown process to address issues of moisture handling, buildup of fines, and pressure differential. Additional lifters were added to the heated section of the tube. Overall solids/condensable recovery was $85 \mathrm{wt} \%$, which is probably low by at least $10 \%$. This presumes $14 \%$ conversion of coal to condensable organic matter and gas, with $25 \%$ of this being gas. This could be a result of generating more gas than expected.

\begin{tabular}{ll} 
Table 3. Test Matrix for Carbonization Optimization \\
Tests in the Rotary Kiln \\
\hline Carbonization Temperature, ${ }^{\circ} \mathrm{C}$ & Reactor \\
\hline 425 & Rotary kiln \\
550 & Rotary kiln \\
600 & Rotary kiln \\
\hline
\end{tabular}


Table 4. Test Conditions for Shakedown Carbonization Tests Using Hagel A Seam Lignite from the Center Mine, $-1 / 8$-in. + 10-mesh Particle-Size Fraction

\begin{tabular}{lccccccc}
\hline Test No.: & 1 & 2 & 3 & $4 \mathrm{~A}^{1}$ & $4 \mathrm{~B}^{2}$ & $5 \mathrm{~A}^{3}$ & $5 \mathrm{~B}^{4}$ \\
\hline Feed Material & Coal & Coal & Coal & $\begin{array}{c}\text { Test } 2 \\
\text { char }\end{array}$ & $\begin{array}{c}\text { Test } 2 \\
\text { char }\end{array}$ & Coal & Coal \\
Feed Moisture, wt\% & 28.6 & 15 & 28.6 & $\mathrm{ND}^{5}$ & $\mathrm{ND}$ & 27.5 & 27.5 \\
Temperature, ${ }^{\circ} \mathrm{C}$ & 425 & 425 & 425 & 425 & 425 & 455 & 455 \\
Tube Incline, & 1 & 1 & 1 & 1 & 5 & 1 & 5 \\
Tube Speed, rpm & 2 & 2 & 2 & 2 & 8 & 1.33 & 8 \\
Feed Rate, lb/hr & 10 & 10 & 20 & 10 & 10 & 10 & 10 \\
Coal Processed, lb & 15 & 15 & 13 & 8.9 & & 10.5 & \\
Char Recovered, lb & 7.05 & 9.4 & 6.35 & 2.8 & 5.7 & 2 & 2.95 \\
Condensate Recovered, lb & 4.45 & 2.8 & 4.11 & & & & 3.07 \\
Product Yield, \% & 47 & 63 & 49 & & 96 & & 47 \\
Iodine No., mg I $\mathrm{I}_{2} / \mathrm{g}$ & 242 & 170 & 187 & 420 & 425 & 420 & 394 \\
\hline
\end{tabular}

${ }^{1}$ Product recovered during the first 105 minutes from the start of feed of Test 4 .

${ }^{2}$ The rest of the product recovered during Test 4 .

${ }^{3}$ Product recovered during the first 165 minutes from the start of feed of Test 5.

${ }^{4}$ The rest of the product recovered during Test 5.

${ }^{5}$ Not determined.

The product yields for Tests 1,3 , and 5 were similar to those obtained in the 1-in. and 3-in. fixed-bed reactors. For reasons unknown, Test 2 had poor yield (insufficient burnout), which could be one explanation for the low estimated surface area (reported as iodine number). Test 1 had better-than-average surface area for chars as compared to chars produced in the fixed-bed reactor at $400^{\circ} \mathrm{C}$. Reprocessing (Test 4) and carbonization at a higher temperature (Test 5) may have a greater influence on surface area for the char. These shakedown tests indicated that the system is capable of producing good intermediate char from North Dakota lignite. After successful completion of shakedown tests, the optimization tests for carbonization were carried out.

\section{Carbonization Process Optimization Tests}

The process optimization tests for carbonization were conducted at three different temperatures: $425^{\circ}, 550^{\circ}$, and $600^{\circ} \mathrm{C}$.

\section{Carbonization Optimization Tests at $425^{\circ} \mathrm{C}$}

Two types of Hagel lignite coal—old Hagel lignite and fresh Hagel A lignite—were sized to nominal $-1 / 8$-in. +10 -mesh material. Old Hagel lignite was obtained from the surplus coal in one of the bunkers in fuel storage, which were being emptied. A 55-gal drum of fresh Hagel A lignite was received from the Center Mine on December 22, 2005, from BNI Coal, Ltd. The coal was sized to $-1 / 8+10$ mesh and stored in nitrogen in the freezer. The results of the proximate and ultimate analysis of the coal are presented in Table 5. The results indicate a higher moisture and fixed-carbon content in the December 22, 2005, sample than was noted in the small sample received in July 2005. 
Table 5. Coal Analysis of Hagel A Center Lignite, received December 22, 2005

\begin{tabular}{lll}
\hline Proximate Analysis, wt\% & \multicolumn{1}{c}{ As-Received } & Moisture-Free \\
\hline Moisture Content & 37.3 & NA $^{1}$ \\
Volatile Matter & 26.65 & 42.52 \\
Fixed Carbon & 31.05 & 49.51 \\
Ash & 5.00 & 7.97 \\
\hline Ultimate Analysis, wt\% & & \\
\hline Hydrogen & 7.01 & 4.56 \\
Carbon & 40.55 & 64.7 \\
Nitrogen & 0.73 & 1.17 \\
Sulfur & 0.76 & 1.22 \\
Oxygen & 45.95 & 20.38 \\
Ash & 5.00 & 7.97 \\
\hline
\end{tabular}

${ }^{1}$ Not applicable.

Table 6 shows the operating conditions, char produced, and condensate recovered for carbonization tests performed using old Hagel and Hagel A (December 22, 2005) coal. Overall, solids/condensable recoveries were $82 \mathrm{wt} \%$ and $86 \mathrm{wt} \%$ using old Hagel and Hagel A (December 22, 2005) coals, respectively. Product yield was higher for carbonization tests using old Hagel coal, and condensate recovery was higher for carbonization tests using Hagel A (December 22, 2005) coal. The difference in moisture and volatile matter content of the two coal samples could be the reason for variations in char yield and condensate recovery.

Table 6. Test Conditions for Carbonization Tests Using Old Hagel A and Hagel A (December 22, 2005) Seam Lignite from the Center Mine, -1/8-in. +10-mesh Particle-Size Fraction

\begin{tabular}{|c|c|c|c|c|c|c|}
\hline Test No.: & 1 & 2 & 3 & 4 & 5 & 6 \\
\hline \multirow[t]{3}{*}{ Feed Material } & Old & Old & Hagel A & Hagel A & Hagel A & Hagel A \\
\hline & Hagel & Hagel & Coal & Coal & Coal & Coal \\
\hline & Coal & Coal & & & & \\
\hline Feed Moisture, wt\% & NA & NA & 37.3 & 37.3 & 37.3 & 37.3 \\
\hline Temperature, ${ }^{\circ} \mathrm{C}$ & 425 & 425 & 425 & 425 & 425 & 455 \\
\hline Tube Incline, $^{\circ}$ & 1 & 1 & 1 & 1 & 1 & 1 \\
\hline Tube Speed, rpm & 2 & 2 & 2 & 2 & 2 & 2 \\
\hline Feed Rate, lb/hr & 10 & 10 & 10 & 10 & 10 & 10 \\
\hline Coal Processed, lb & 45 & 45 & 15 & 45 & 45 & 45 \\
\hline Char Recovered, lb & 19 & 21.33 & 6.35 & 19.35 & 20.2 & 18.3 \\
\hline Condensate Recovered, lb & 15.15 & 14.05 & 6.5 & 11.84 & 27.55 & 14.25 \\
\hline Product Yield, \% & 43 & 48 & 43 & 43 & 45 & 41 \\
\hline Iodine No., $\mathrm{mg} \mathrm{I}_{2} / \mathrm{g}$ & 467 & 467 & 467 & 442 & 442 & 442 \\
\hline
\end{tabular}




\section{Carbonization Optimization Tests at $550^{\circ}$ and $600^{\circ} \mathrm{C}$}

Two types of Hagel A lignite coal were sized to nominal -1/8-in. +10-mesh material. Both types of coal were received on July 6, 2006, from BNI Coal, Ltd. The coal types were described as B21.8, CS 230, HA (Type A) and W/M5.36, CS 94, HA (Type B).

Carbonization of coal was conducted at higher temperatures, $550^{\circ}$ and $600^{\circ} \mathrm{C}$, compared to the previous carbonization temperature, $425^{\circ} \mathrm{C}$. Carbonization was conducted on a continuous basis as described before.

Table 7 shows the operating conditions, char produced, and condensate recovered for carbonization tests performed using two types of coal. Product yield was higher for carbonization tests using Coal Type A compared to Coal Type B. The product char yield was $38.3 \%$ and 35.8\% for Coal Type A and Coal Type B, respectively. Seventy-five lb of Type A coal was carbonized at $550^{\circ} \mathrm{C}$, the remaining $90 \mathrm{lb}$ of Type A coal at $600^{\circ} \mathrm{C}$, and all $150 \mathrm{lb}$ of Type B coal at $600^{\circ} \mathrm{C}$. The difference in moisture and volatile contents of two types of coal and carbonization temperatures could be reasons for variation in char yield. The char yield for these runs was also lower than the char yield for previously prepared char at $425^{\circ} \mathrm{C}$, resulting from increased burnout at the higher temperatures.

The iodine numbers of char produced from the same coal (Type A) at $550^{\circ}$ and $600^{\circ} \mathrm{C}$ were 350 and $380 \mathrm{mg} \mathrm{I} / \mathrm{g}$, respectively (Table 7). Higher carbonization temperature drove out more volatile matter from the carbon structure and produced more surface area. The same trend was also evident from lab-scale optimization tests. From the carbonization optimization tests, it was concluded that $600^{\circ} \mathrm{C}$ was the best carbonization temperature of those tested for producing activated carbon from Center lignite. Ideally, carbonization temperature at a sufficiently high temperature should continue to see a decrease in performance parameters.

\begin{tabular}{|c|c|c|}
\hline Test No.: & 1 & 2 \\
\hline Feed Material & Type A & Type B \\
\hline Feed Moisture, wt\% & N/A & N/A \\
\hline Temperature, ${ }^{\circ} \mathrm{C}$ & $550-600$ & 600 \\
\hline Tube Incline, $^{\circ}$ & 1 & 1 \\
\hline Tube Speed, rpm & 2 & 2 \\
\hline Feed Rate, lb/hr & 10 & 10 \\
\hline Coal Processed, lb & 165 & 150 \\
\hline Char Recovered, lb & 63.15 & 53.7 \\
\hline Condensate Recovered, lb & 38.2 & 36.95 \\
\hline Product Yield, \% & 38.27 & 35 \\
\hline Iodine No., mg $\mathrm{I}_{2} / \mathrm{g}$ & $350,{ }^{1} 380^{2}$ & 410 \\
\hline
\end{tabular}




\section{Steam Activation of Carbonized Char}

Steam activation of carbonized char consisted of shakedown tests and process optimization tests. After successful completion of shakedown tests, tests were conducted to investigate the effect of process parameters such as steam flow rate, activation temperature and residence time on the product quality. The test matrix for steam activation optimization tests is in Table 8.

\section{Shakedown Tests}

Two shakedown steam activation tests were performed to evaluate the pilot-scale rotary kiln system. Table 9 shows the operating conditions for the two tests, which were carried out at $775^{\circ}$ and $840^{\circ} \mathrm{C}\left(1330^{\circ}\right.$ and $\left.1540^{\circ} \mathrm{F}\right)$, respectively, using steam superheated to a nominal $315^{\circ} \mathrm{C}$ $\left(600^{\circ} \mathrm{F}\right)$. The feed char was a composite of five char production tests prepared under the same conditions. The weighted average iodine number for the five-char composite was $315 \mathrm{mg} \mathrm{I}_{2} / \mathrm{g}$. The iodine numbers for the $775^{\circ}$ and $840^{\circ} \mathrm{C}$ tests were 457 and $682 \mathrm{mg} \mathrm{I} / \mathrm{g}$, respectively. Based on iodine number comparison, higher activation temperature $\left(840^{\circ} \mathrm{C}\right)$ produced more surface area compared to lower activation temperature $\left(775^{\circ} \mathrm{C}\right)$ even at low residence time. Optimization tests were carried out based on the results obtained during shakedown test. The results of optimization tests are described below.

Table 8. Test Matrix for Steam Activation Optimization Tests in Rotary Kiln

\begin{tabular}{lccc}
\hline Activation Temperature, ${ }^{\circ} \mathrm{C}$ & Reactor & Steam Rate, lb/hr & Residence Time, min \\
\hline 775 & Rotary kiln & 2 & 89 \\
840 & Rotary kiln & $2,4,6$ & 30,45 \\
900 & Rotary kiln & 4 & $30,60,90$ \\
\hline
\end{tabular}

Table 9. Test Conditions for Shakedown Steam Activation Test Using Hagel A Seam Lignite from the Center Mine

\begin{tabular}{lcc}
\hline Activation Temperature, $^{\circ} \mathrm{C}$ & 775 & 840 \\
Tube Incline, $^{\circ}$ & 1 & 1 \\
Tube Speed, rpm & 1.33 & 2.66 \\
Estimated Residence Time, min & 89 & 45 \\
Char Fed, lb & 5 & 5 \\
Char Feed Rate, lb/hr & 10 & 10 \\
Carbon Recovered, lb & 2.8 & 3.82 \\
Steam Rate, lb/hr & 2 & 2 \\
Processing Time, hr & 2 & 1.93 \\
Condensate, lb & 1.55 & 1.74 \\
Maximum $\mathrm{H}_{2}, \%$ & 27.5 & 37.6 \\
Maximum $\mathrm{CO}_{0} \%$ & 10.3 & 16.9 \\
Maximum $\mathrm{CH}_{4}, \%$ & 4.5 & 4.7 \\
Maximum $\mathrm{CO}_{2}, \%$ & 7.7 & 9.3 \\
Iodine No., $\mathrm{mg} \mathrm{I}_{2} / \mathrm{g}$ & 457 & 682 \\
\hline
\end{tabular}




\section{Activation Process Optimization Tests}

Steam activation of the carbonized char focused on optimization of the activation process. The parameters tested for activation of carbonized char were steam flow rate, activation temperature, and residence time.

\section{Effect of Steam Flow Rate and Temperature}

After the successful completion of shakedown tests, the effects of two parameters such as steam flow rate and temperature on activated carbon were investigated. The old Hagel lignite carbonized at $425^{\circ} \mathrm{C}$ was used to carry out multiple tests at different steam flow rates keeping the operating temperature constant. Char prepared from Hagel A (December 22, 2005) at $425^{\circ} \mathrm{C}$ was used for tests investigating the effects of different operating temperatures keeping the steam flow rate constant. Other parameters, such as tube slope and rotation, which determine the residence time of the char in the heated zone, were kept constant. Table 10 shows the operating conditions, activated carbon produced, condensate recovered, and gas composition for the optimization tests performed using old Hagel-derived char and Hagel A (December 22, 2005)-derived char.

Steam condensation occurred during steam activation, especially at the higher steam flow rate used during the old Hagel activation. This resulted in noticeable wetness in the activated carbon product as it was removed from the collection pot. The product was dried in an oven set at $109^{\circ} \mathrm{C}\left(228^{\circ} \mathrm{F}\right)$ in $\mathrm{N}_{2}$. To minimize future steam condensation, insulation was added to the discharge end of the rotary kiln unit. It was observed that new insulation helped to eliminate steam condensation.

Table 10. Steam Activation Test Conditions for Optimization of Rotary Kiln Parameters Such as Steam Flow Rate and Temperature

\begin{tabular}{lcccccc}
\hline Feed Char & \multicolumn{3}{c}{ Old Hagel A } & \multicolumn{3}{c}{ Hagel A (December 22, 2005) } \\
\hline Activation Temperature, ${ }^{\circ} \mathrm{C}$ & 840 & 840 & 840 & 800 & 840 & 900 \\
Tube Incline, ${ }^{\circ}$ & 1 & 1 & 1 & 1 & 1 & 1 \\
Tube Speed, rpm & 2.66 & 2.66 & 2.66 & 2.66 & 2.66 & 2.66 \\
Estimated Residence Time, min & 45 & 45 & 45 & 45 & 45 & 45 \\
Char Fed, lb & 10 & 10 & 18.85 & 10 & 10 & 10 \\
Char Feed Rate, lb/hr & 10 & 10 & 10 & 10 & 10 & 10 \\
Carbon Recovered, lb & 5.95 & 4.85 & 10.86 & 5.65 & 5.1 & 1.25 \\
Steam Rate, lb/hr & 6 & 6 & 4 & 4 & 4 & 4 \\
Processing Time, hr & 2.5 & 3.8 & 5 & 2.5 & 2.5 & 2.5 \\
Condensate, lb & 11.0 & 10.1 & 11 & 4.5 & 5.4 & 5.85 \\
Maximum $\mathrm{H}_{2}, \%$ & 41.1 & 37.9 & 42.2 & 35 & 37.69 & 32.37 \\
Maximum CO, \% & 15.99 & 13.34 & 16.29 & 12.33 & 14.46 & 15.55 \\
Maximum CH $\mathrm{CH}_{4} \%$ & 2.75 & 3.84 & 4.24 & 4.55 & 4.49 & 1.11 \\
Maximum $\mathrm{CO}_{2}, \%$ & 10.11 & 10.86 & 10.81 & 7.9 & 8.63 & 6.64 \\
Iodine No., $\mathrm{mg} \mathrm{I}_{2} / \mathrm{g}$ & 653 & 653 & 741 & 620 & 773 & 806 \\
\hline
\end{tabular}


Air leakage in the system was observed during steam activation at the highest temperature $\left(900^{\circ} \mathrm{C}\left[1652^{\circ} \mathrm{F}\right]\right)$. This resulted in combustion of char and a lower yield of activated carbon. The activated char also contained white material, which was believed to be ash.

Operating problems were encountered during steam activation tests at $6 \mathrm{lb} / \mathrm{hr}$ of steam flow rate. Activated carbon produced from Old Hagel coal-derived char activated with 6 and $4 \mathrm{lb} / \mathrm{hr}$ of steam flow rate produced iodine numbers of 653 and $741 \mathrm{mg} \mathrm{I} / \mathrm{g}$, respectively. Therefore, the 4-lb/hr steam flow rate was determined to be the optimum manageable steam flow rate for the current pilot-scale rotary kiln system. Further optimization tests were conducted at this optimum $4 \mathrm{lb} / \mathrm{hr}$ of steam flow rate.

Table 10 also shows iodine number of activated carbon produced from Hagel A (December 22, 2005)-derived char at three activation temperatures $\left(800^{\circ}, 840^{\circ}\right.$, and $\left.900^{\circ} \mathrm{C}\right)$ with the same steam flow rate and residence time. Based on the iodine number of the activated carbons, higher activation temperatures produced more surface area compared to lower activation temperatures. Further optimization tests were conducted on the steam activation process to investigate the effect of residence time as well as temperature.

\section{Effect of Residence Time and Temperature}

The effect of two parameters, residence time and temperature, on activated carbon was investigated. Chars produced from two types of coal, B21.8, CS 230, HA (Type A) and W/M5.36, CS 94, HA (Type B) received on July 6, 2006, were mixed. Aliquots were carbonized at two different temperatures $\left(550^{\circ}\right.$ and $\left.600^{\circ} \mathrm{C}\right)$ using the homogenized char as the feed material for steam activation. Steam activation was carried on at around $5.5 \mathrm{lb} / \mathrm{hr}$ of char feed rate and $4 \mathrm{lb} / \mathrm{hr}$ of steam flow rate. Activation was carried out at $900^{\circ} \mathrm{C}$ with residence times of $30 \mathrm{~min}$, $60 \mathrm{~min}$, and $90 \mathrm{~min}$ and at $840^{\circ} \mathrm{C}$ with residence times of $30 \mathrm{~min}$ and $45 \mathrm{~min}$. Table 11 shows the operating conditions for the optimization tests performed using mixed char produced from two types of coal.

The iodine numbers of activated carbon produced at 30-min residence time at $840^{\circ}$ and $900^{\circ} \mathrm{C}$ were 565 and $699 \mathrm{mg} \mathrm{I}_{2} / \mathrm{g}$, respectively. Higher activation temperatures generated more surface area than lower activation temperatures. The iodine numbers (Table 11) of activated carbon produced at $900^{\circ} \mathrm{C}$ at three residence times increased with increasing residence time. Longer residence time was also better at producing greater surface area than shorter residence time. This same trend was observed in bench-scale tests.

Table 11. Steam Activation Test Conditions for Optimization of Rotary Kiln Parameters Such as Residence Time and Temperature

\begin{tabular}{lccccc}
\hline Activation Temperature, ${ }^{\circ} \mathrm{C}$ & 900 & 900 & 900 & 840 & 840 \\
Tube Incline, ${ }^{\circ}$ & 2 & 2 & 1 & 2 & 1 \\
Tube Speed, rpm & 2 & 1 & 1.31 & 2 & 2.66 \\
Estimated Residence Time, min & 30 & 60 & 90 & 30 & 45 \\
Char Feed Rate, lb/hr & 5.5 & 5.5 & 5.5 & 5.5 & 5.5 \\
Steam Rate, lb/hr & 4 & 4 & 4 & 4 & 4 \\
Iodine No., $\mathrm{mg} \mathrm{I} / \mathrm{g}$ & 699 & 767 & 790 & 565 & 600 \\
\hline
\end{tabular}


Based on the optimization tests, higher activation temperatures and longer residence times produced activated carbons with higher surface area. Based on the iodine numbers of activated carbon produced at the EERC from Center lignite coal, the best process conditions for the steam activation process were at $900^{\circ} \mathrm{C}$ and 90 -min residence time.

\section{Task 2 - Sorbent Property Investigation}

To investigate the properties of sorbents prepared during the course of this project, the following procedures were conducted:

1. Characterization of char and activated carbon

2. Bench-scale testing of activated carbon

3. Pilot-scale testing of activated carbon

\section{Characterization of Activated Carbon}

The iodine number for the activated carbon is a critical parameter that is used as a measure of the surface area of the product. Pilot-scale tests confirmed the importance of activation temperature as a key variable impacting product surface area. Pilot-scale activated carbon produced at $900^{\circ} \mathrm{C}$ and with 30-, 60-, and 90-min residence times also confirmed that longer residence time increases the iodine number of activated carbon (Table 11). An activated carbon with a surface area in the range of 600 to $800 \mathrm{mg} \mathrm{I} / \mathrm{g}$ was obtained from the activated carbon produced from Center lignite in the pilot-scale rotary kiln system at activation temperatures greater than $800^{\circ} \mathrm{C}$ (Figure 9). This product quality was superior to DARCO FGD, which has an iodine number in the range of 500 to $600 \mathrm{mg} \mathrm{I} / \mathrm{g}$ product, and to Rheinbraun's HOK activated coke product, which has an iodine number of around $275 \mathrm{mg} \mathrm{I} / \mathrm{g}$.

\section{Bench-Scale Mercury Capture Tests}

The steam-activated carbons were ground to pass through a 400-mesh sieve in preparation for the bench-scale mercury capture screening. The mercury capture tests performed on the EERC bench-scale mercury capture screening system and associated results are described below.

\section{Preliminary Bench-Scale Mercury Capture Tests}

The activated carbon produced at $840^{\circ} \mathrm{C}$ and 45 -min residence time during shakedown in the pilot-scale rotary kiln and carbon activated in 1-in. bench-scale reactor at different operating conditions were tested for mercury capture capability of carbon in a bench-scale mercury capture screening system. The activated carbons were made from Hagel A lignite coal received from BNI coal on July 28, 2005. The analysis of this coal is given in a previous section. The commercial DARCO FGD carbons were also tested to compare the mercury capture capability of the EERC-produced activated carbon and commercially available carbon. Figure 10 shows the percentage of inlet mercury measure downstream of the fixed-bed activated carbon as both total mercury and elemental mercury for the different activated carbon mercury capture tests. The figure shows that inlet total mercury concentration drops to a minimum of 


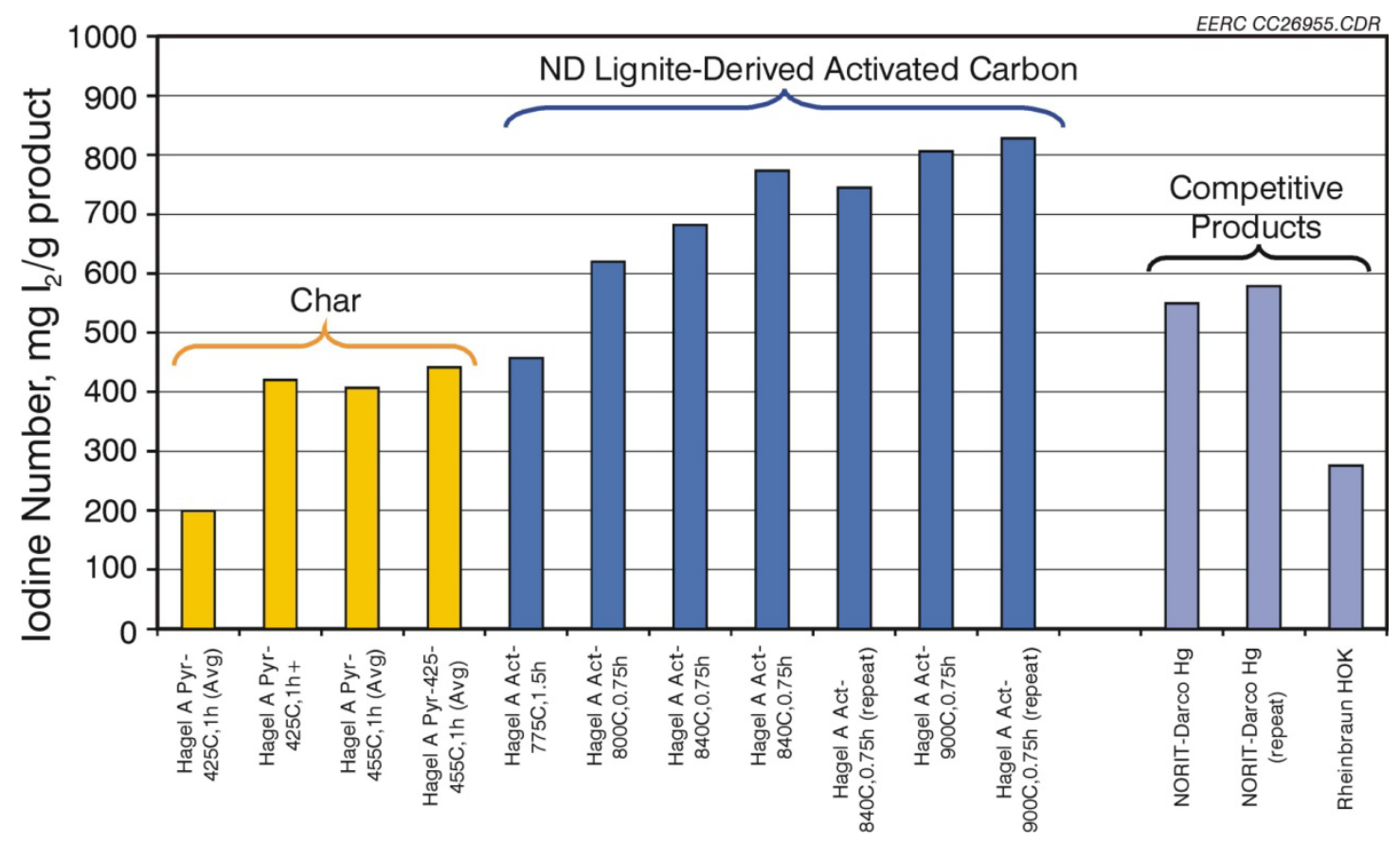

Figure 9. Iodine number for samples of char and activated carbon generated in a pilot-scale rotary kiln from Center lignite compared to commercially available activated carbon.

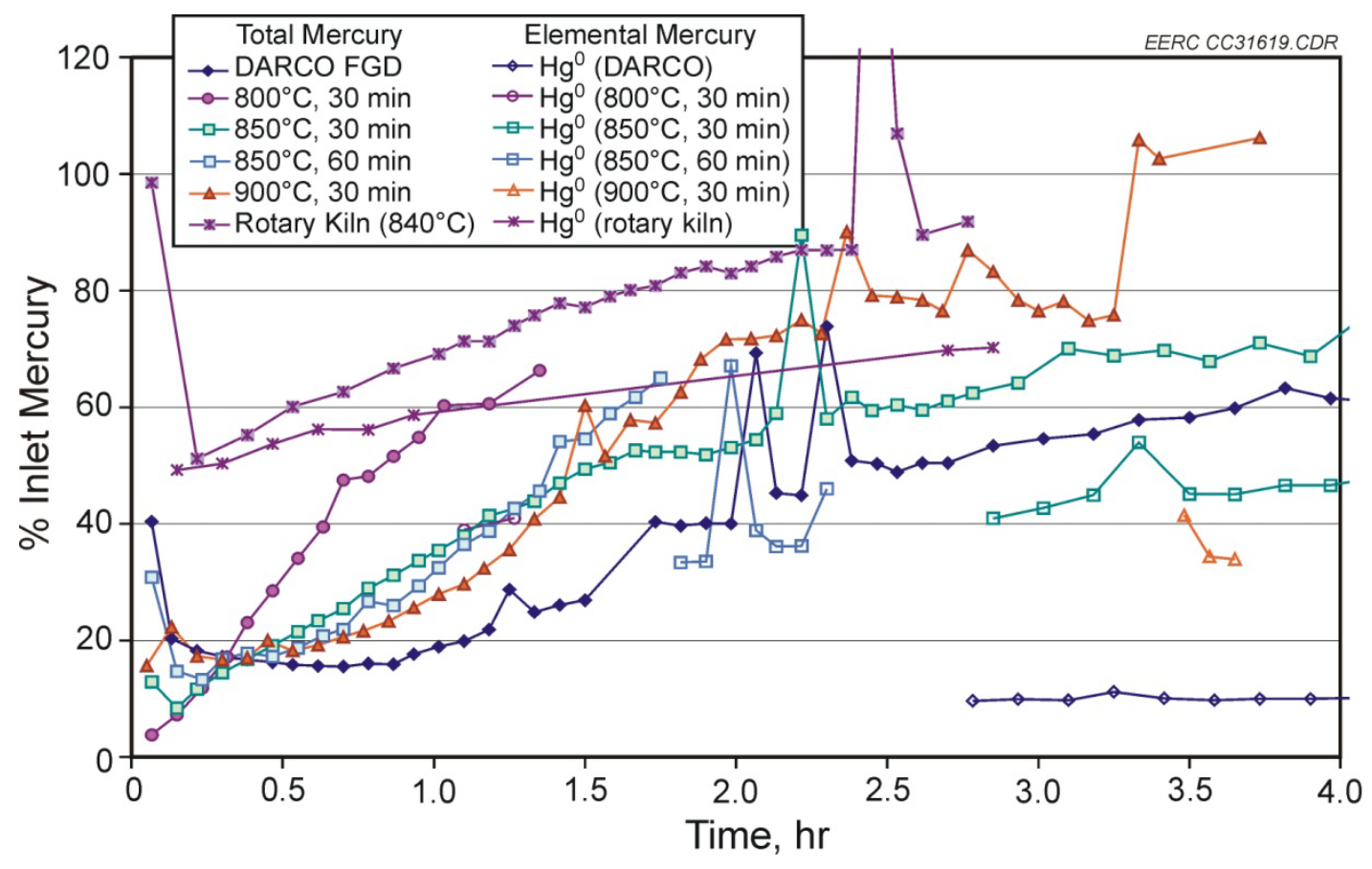

Figure 10. Results of bench-scale mercury capture screening of initial carbons activated in the 1-in. bench-scale reactor and in the rotary kiln shakedown test under low-acid simulated flue gas conditions. 
approximately 18\% after 30 minutes during the DARCO FGD test. The carbon made in a 1-in. bench-scale reactor at different operating conditions captured mercury as well as commercialgrade DARCO FGD initially. However, these carbons appear to have less capacity than the DARCO FGD after 30 min of exposure to simulated flue gas. The activated carbon made during shakedown rotary kiln tests at $840^{\circ} \mathrm{C}$ captured $50 \%$ of total inlet mercury.

\section{Mercury Capture Tests for Carbon Activated at $840^{\circ}$ and $900^{\circ} \mathrm{C}$ in the Rotary Kiln}

The bench-scale mercury capture tests were carried out to compare the commercially available activated carbon DARCO FGD and activated carbon produced from Center Mine lignite under activated carbon optimization process conditions. The activated carbon was produced at $840^{\circ}$ and $900^{\circ} \mathrm{C}$ with a steam flow rate of $4 \mathrm{lb} / \mathrm{hr}$. The char used for producing activated carbon at the conditions mentioned here was produced from Hagel A (December 22, 2005). The $840^{\circ} \mathrm{C}$ carbon was treated in three ways. One sample was washed with distilled water followed by an application of 50 and $200 \mathrm{ppm} \mathrm{HCl}$ to separate aliquots. Another sample was washed with $0.1 \mathrm{~N}$ aqueous $\mathrm{HCl}$, and a third sample was soaked in $0.1 \mathrm{~N} \mathrm{HCl}$ and dried without rinsing. The $900^{\circ} \mathrm{C}$ carbon was treated by water-washing and washing with $1 \mathrm{~N} \mathrm{HCl}$.

Figure 11 shows the percentage of inlet mercury measured downstream of the fixed-bed carbon filter for bench-scale mercury capture tests performed with commercial DARCO FGD activated carbon and activated carbon made from Hagel A (December 22, 2005) at $840^{\circ}$ and $900^{\circ} \mathrm{C}$. The figure clearly shows the superiority of Hagel A-derived activated carbon at $900^{\circ} \mathrm{C}$ and a 4-lb/hr steam flow rate compared to commercial DARCO FGD carbon. As the figure indicates, the \% of total inlet mercury decreased to a minimum of $4 \%$ during mercury capture tests performed with the rotary kiln-produced activated carbon at $900^{\circ} \mathrm{C}$ and $4 \mathrm{lb} / \mathrm{hr}$ of steam, whereas the total inlet mercury decreased to a minimum of $20 \%$ during mercury capture tests performed with DARCO FGD.

As activated carbons produced at $840^{\circ} \mathrm{C}$ were not as effective at mercury capture as carbons produced at $900^{\circ} \mathrm{C}$ with the same $4-\mathrm{lb} / \mathrm{hr}$ steam rate, the activated carbon production process was further optimized, taking into account two other parameters, residence time and the ratio of feed char to steam flow.

\section{Mercury Capture Tests for Activated Carbon Made in the 1-inch Reactor}

The activated carbons produced in the 1-inch bench-scale reactor at different operating conditions were tested for mercury capture capability in the bench-scale mercury capture screening system. The activated carbons were made from Hagel A lignite coal received on June 21, 2006. Figure 12 shows the percentage of inlet mercury for the different activated carbon mercury capture tests. The mercury capture capability of activated carbon made from char produced at $600^{\circ} \mathrm{C}$ was better at mercury capture than that of activated carbon made from char produced at $500^{\circ} \mathrm{C}$. This bench-scale helped determine optimum operating conditions for carbonization temperature $\left(600^{\circ} \mathrm{C}\right)$ in the pilot-scale rotary kiln. For subsequent rotary kiln production, char was produced at $600^{\circ} \mathrm{C}$, which proved to be a more effective carbonization temperature. 


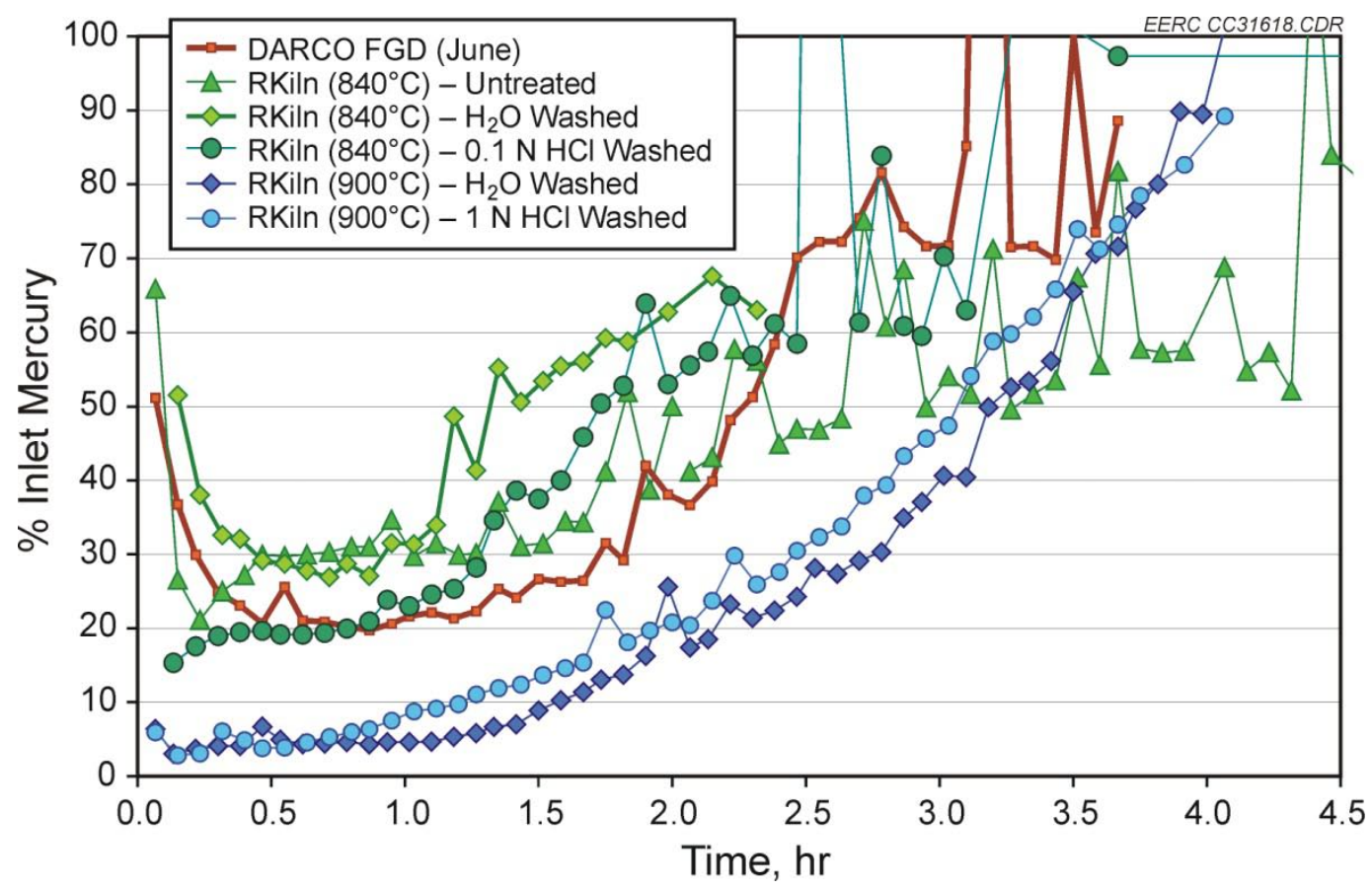

Figure 11. Bench-scale mercury capture data for carbons activated at rotary kiln optimization conditions and DARCO FGD in a low-acid simulated flue gas.

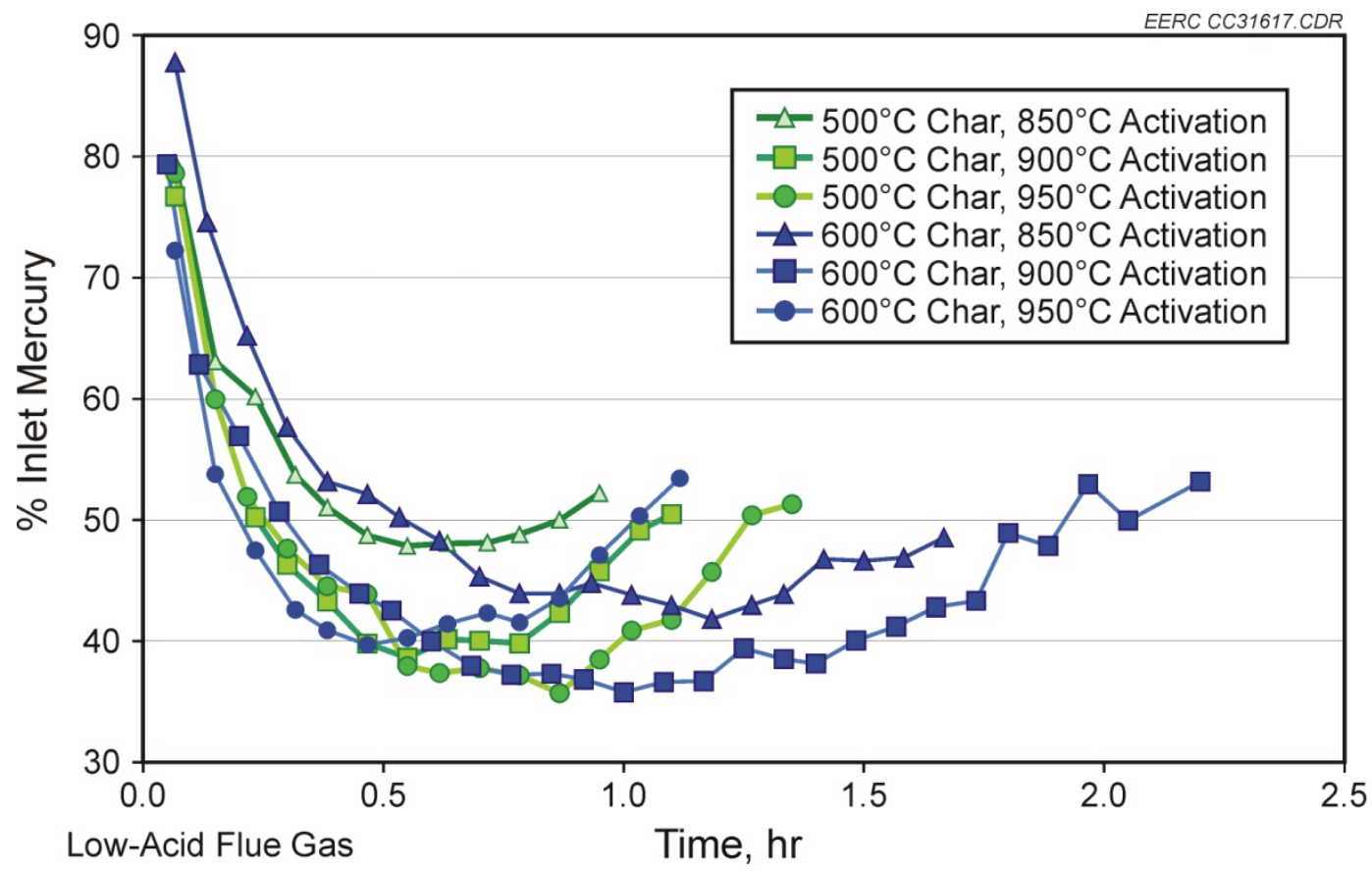

Figure 12. Results of bench-scale mercury capture screening of carbons activated in the 1-in. bench-scale reactor under low-acid simulated flue gas conditions. 


\section{Mercury Capture Tests for Carbon Activated at Different Residence Times and Temperatures in the Rotary Kiln}

Bench-scale mercury capture tests were conducted to investigate the effect of residence time and activation temperature on the mercury capture capability of activated carbon. The activated carbon was made at temperatures of $850^{\circ} \mathrm{C}$ with residence times of 30 and 45 min and $900^{\circ} \mathrm{C}$ with residence times of 30,60 , and $90 \mathrm{~min}$. The activated carbons made at $900^{\circ} \mathrm{C}$ with $30-$ and 90-min residence times were also water-washed to test in the bench-scale mercury capture test system. Figure 13 shows that both activation temperature and residence time have a positive effect on the mercury capture capability of activated carbon. The water-washed activated carbon made at $900^{\circ} \mathrm{C}$ and 90 -min residence time captured $90 \%$ of total inlet mercury. The previous bench-scale mercury tests showed that the commercial DARCO FGD captured a maximum of $80 \%$ of total inlet mercury (Figure 11). These bench-scale tests confirmed the superiority of Center lignite-derived activated carbon $\left(900^{\circ} \mathrm{C}\right.$ and $90-\mathrm{min}$ residence time) compared to commercial DARCO FGD. The test also confirmed the positive effect of higher activation temperature and longer residence time on better mercury capture capability of activated carbon. This results of this test also indicate that of the conditions examined, $900^{\circ} \mathrm{C}$ and 90 -min residence time are the optimum process conditions for steam activation in both the fixed-bed and rotary kiln reactors.

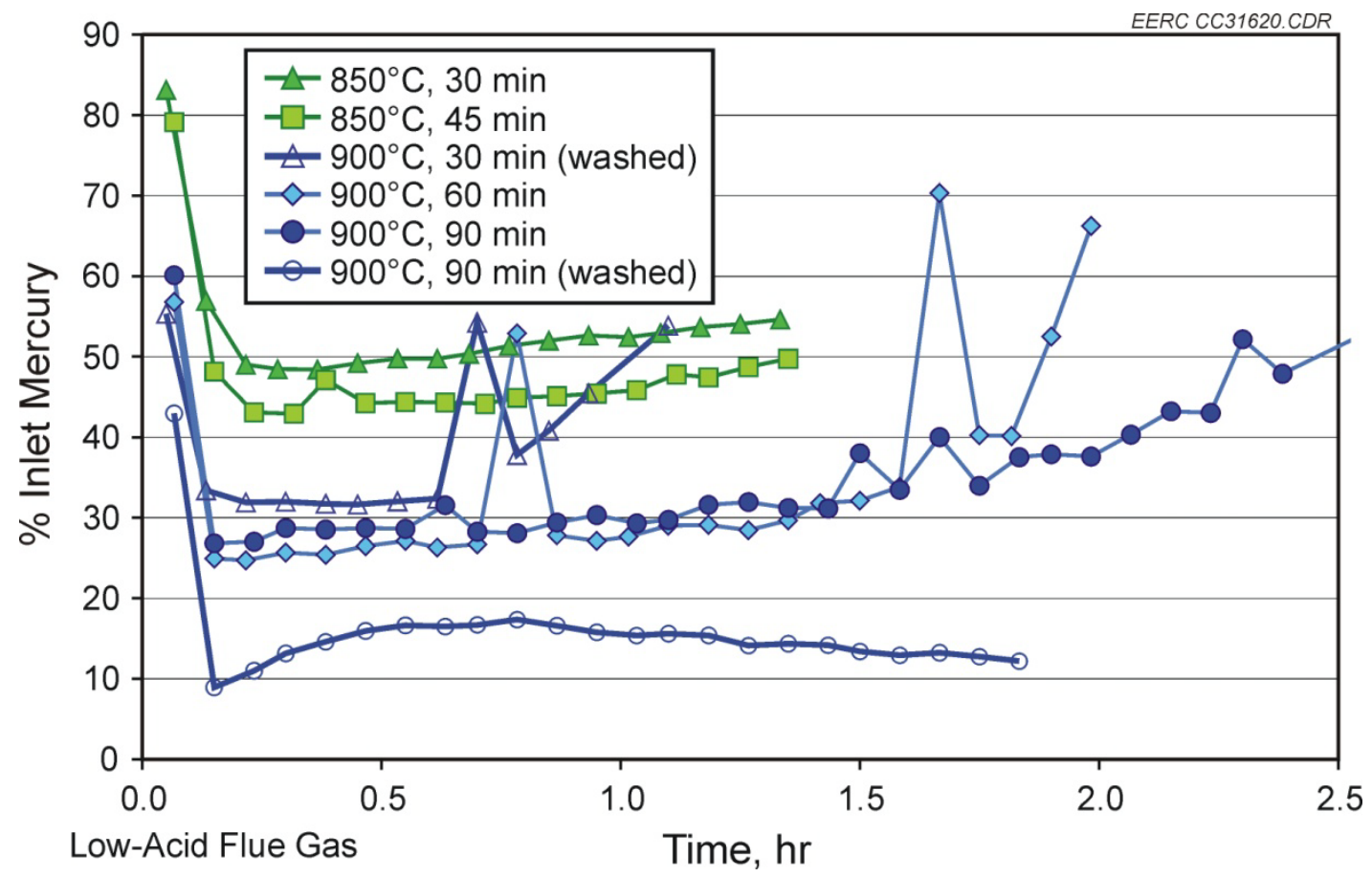

Figure 13. Bench-scale mercury capture data for carbons activated at rotary kiln optimization conditions. 


\section{Pilot-Scale and Slipstream Testing of Activated Carbon}

To investigate the mercury capture capability of the activated carbon produced during rotary kiln shakedown and optimization process conditions, pilot-scale mercury capture testing was conducted in two of the EERC's pilot-scale combustors, the PTC and the CTF. A slipstream baghouse test was conducted at a Texas power plant.

\section{PTC Activated Carbon Test}

Activated carbon steam-activated at $840^{\circ} \mathrm{C}$ during the rotary kiln shakedown runs was ground to less than 200-mesh size and injected into the PTC flue gas stream to test the mercury capture capability of activated carbon. The PTC flue gas was a product of subbituminous coal combustion, the mercury content of which was less than $3.5 \mu \mathrm{g} / \mathrm{dNm}^{3}$. The particulate control device (PCD) through which the flue gas was directed was an ESP. Figure 14 shows the mercury content of the flue gas upstream and downstream of the ESP during baseline and carbon injection conditions. The figure shows that a decrease in the outlet mercury level occurred after the North Dakota-derived activated carbon was injected. The outlet mercury level decreased further when the activated carbon was combined with a proprietary EERC treatment. Figure 15 compares the mercury removal rates for these testing periods with the mercury removal rate of commercially available DARCO Hg. Based on this ESP-only test, the Center Mine-derived activated carbon

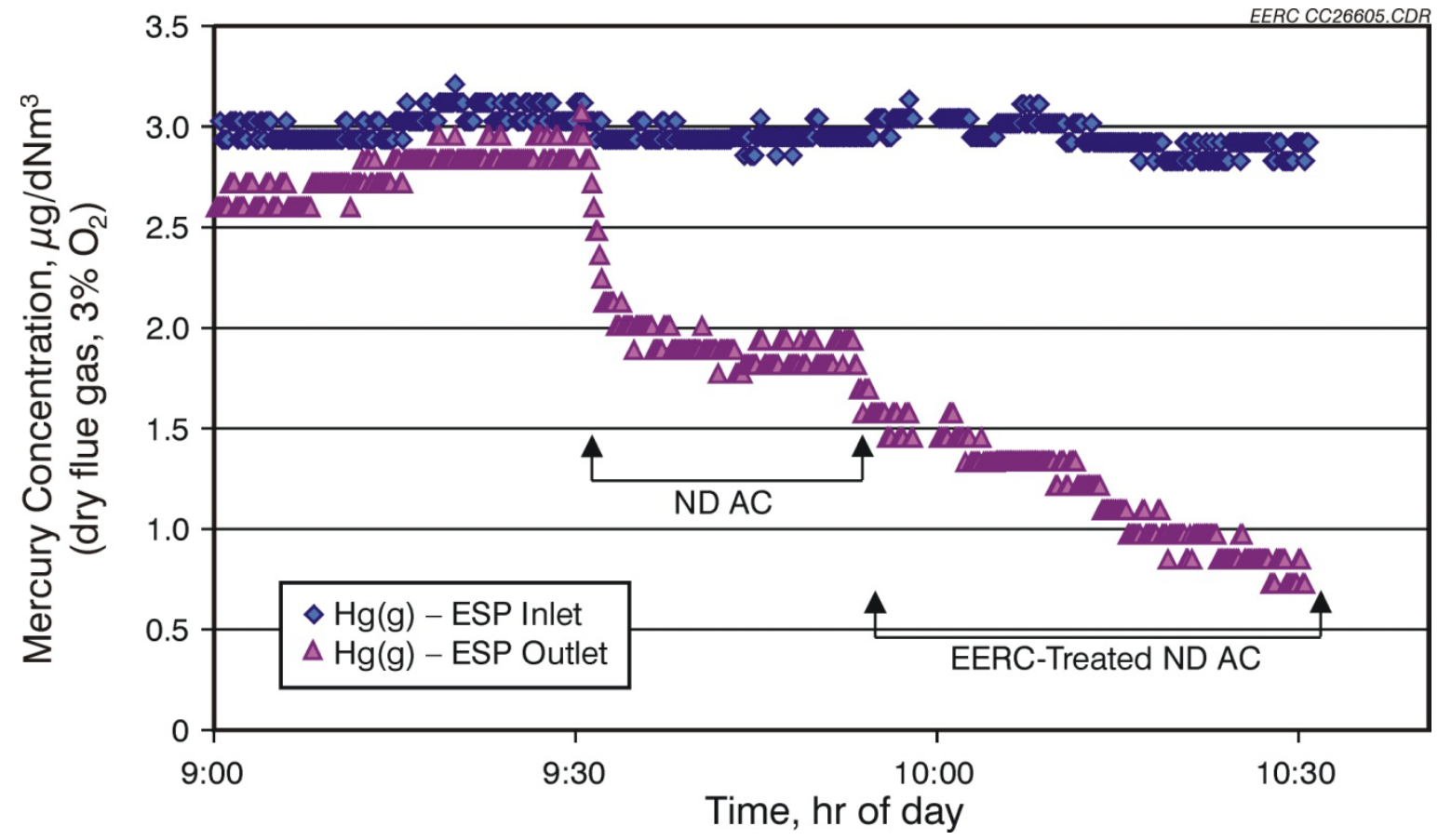

Figure 14. Mercury emissions from a pilot-scale ESP in a subbituminous coal flue gas during baseline conditions and injection of Center Mine lignite-derived carbon injection as a mercury sorbent (AC is activated carbon). 


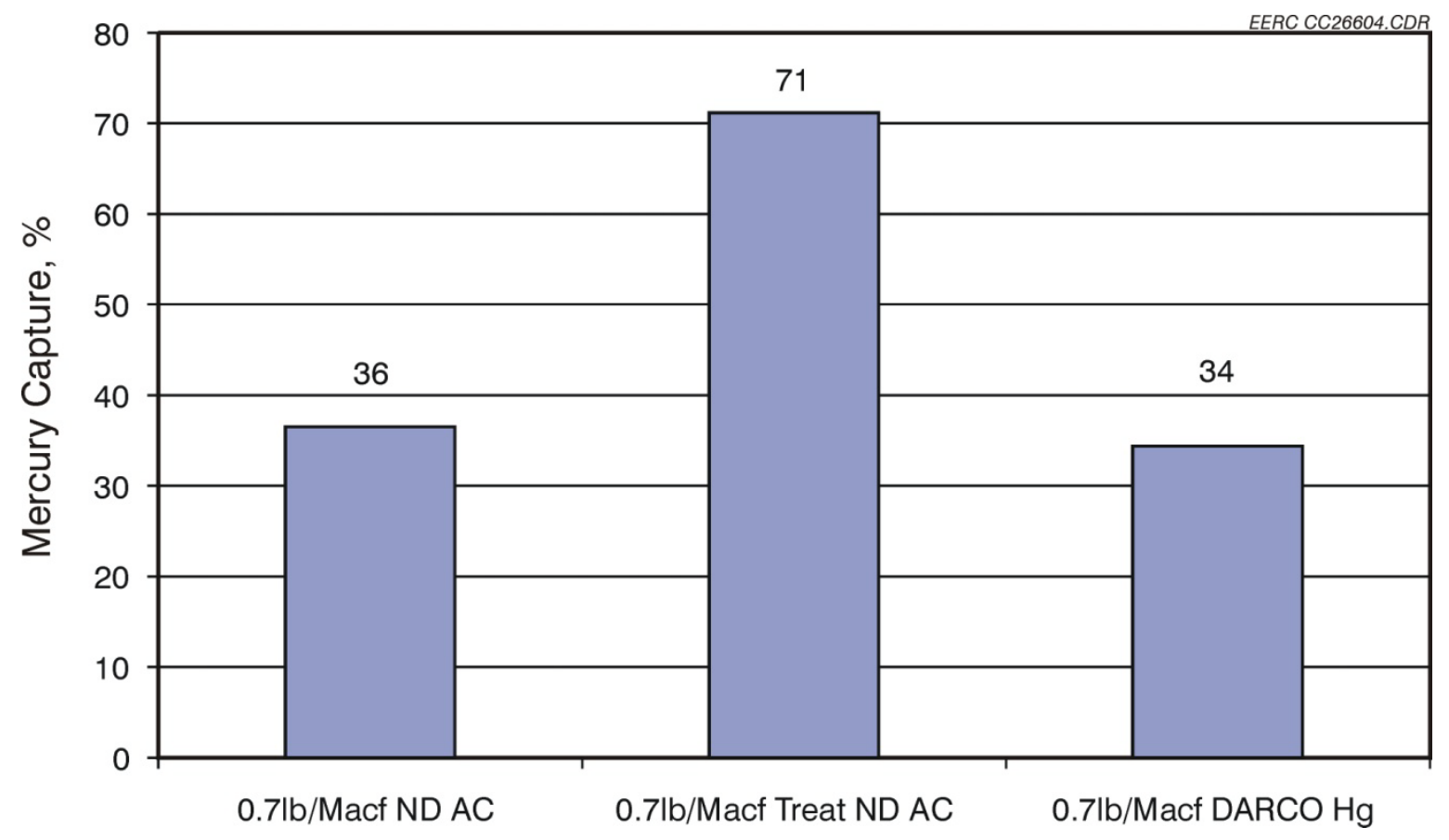

Figure 15. Mercury capture in a pilot-scale ESP in subbituminous coal flue gas using Center Mine lignite-derived and DARCO ${ }^{\circledR} \mathrm{Hg}$ activated carbon injection as mercury sorbents.

performed as well as the commercial carbon. Figure 16 compares the performance of this activated carbon in the PTC ESP to DARCO FGD injected under several PCD configurations at the pilot and full scale. The performance of the untreated activated carbon compared well with the DARCO FGD in an ESP-only configuration in a DOE full-scale system burning Powder River Basin subbituminous coal.

After successful completion of rotary kiln shakedown tests for activated carbon production, the activated carbon was produced at various optimization process conditions. The mercury capture test results for activated carbon during process optimization are described in the following sections.

\section{Slipstream Baghouse Test at a Texas Power Plant}

As a follow-up to earlier testing in the pulverized coal pilot-scale test facility, where similar or better performance for mercury removal with North Dakota lignite-derived activated carbon compared to DARCO FGD was obtained, the EERC tested its product in a slipstream baghouse at a Texas power plant. The data in Table 12 show that the activated carbon made from Hagel A lignite attained 70\% mercury removal beyond the native baghouse capture at an injection rate of $1 \mathrm{lb} /$ Macf. Figure 17 shows that outlet mercury removal by North Dakota activated carbon is within the range of mercury removal by commercial DARCO Hg. This activated carbon was made at $840^{\circ} \mathrm{C}$ and 45 -min residence time. The bench-scale tests described previously also show that activated carbons made at $840^{\circ} \mathrm{C}$ were not as effective as commercial 


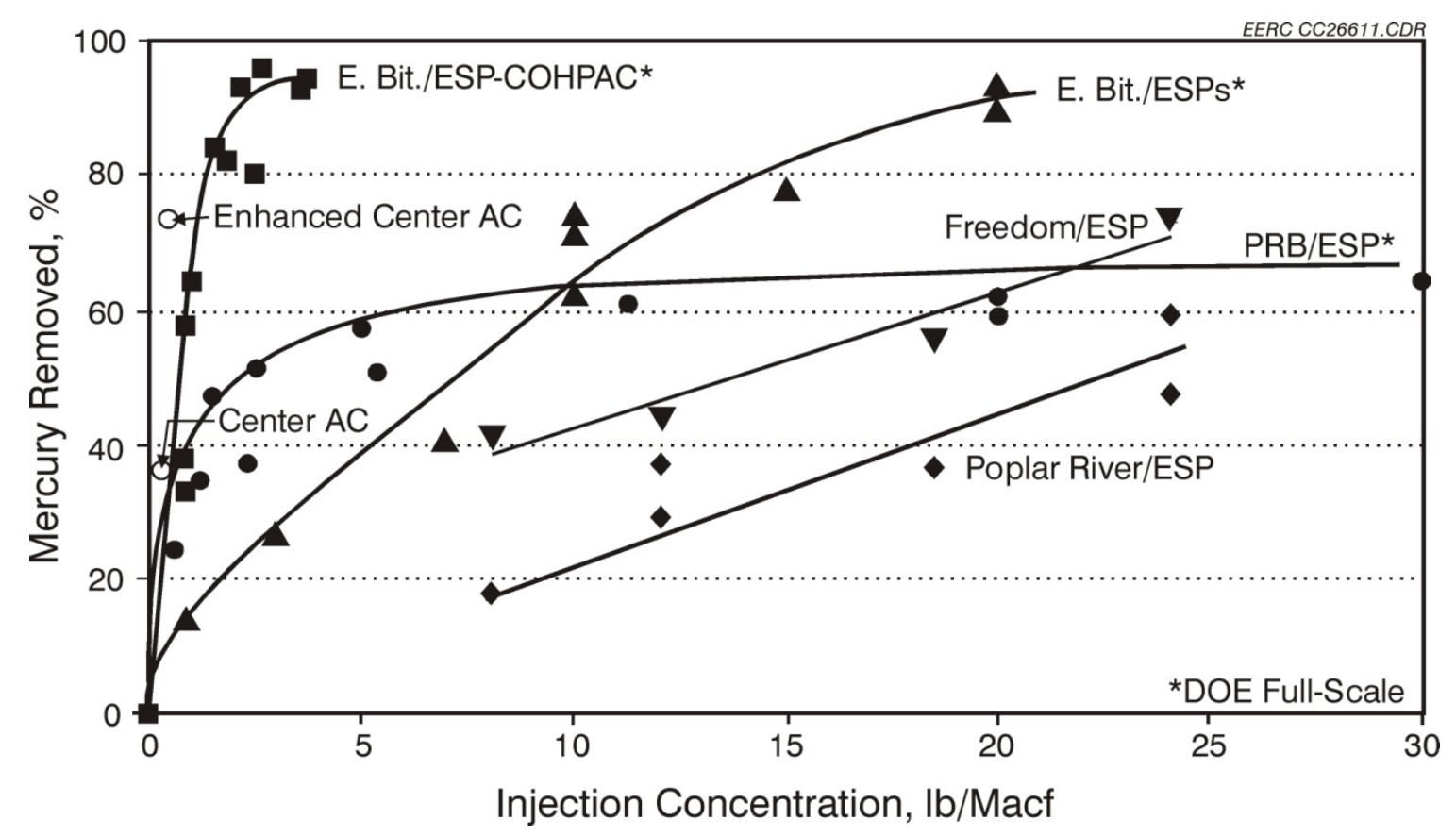

Figure 16. Pilot-scale ESP (9) and full-scale TOXECON ${ }^{\mathrm{TM}}$ and ESP (10) mercury removal efficiencies as a function of activated carbon injection rate for DARCO Hg and Center lignite-derived activated carbon.

Table 12. Performance of Activated Carbon Prepared from North Dakota Lignite and DARCO ${ }^{\circledR} \mathrm{Hg}$ in a Slipstream Baghouse Containing Subbituminous Flue Gas (\% Mercury Removal)

\begin{tabular}{lccc}
\hline & Initial Outlet & \multicolumn{2}{c}{ Injection Rate, lb/Macf } \\
& Mercury, $\mu \mathrm{g} / \mathrm{dNm}^{3}$ & 0.5 & 1 \\
\hline Hagel A-Derived Carbon $\left(840^{\circ} \mathrm{C}\right)$ & 5.2 & $57 \%$ & $70 \%$ \\
DARCO Hg & $6.0-20$ & $25 \%-77 \%$ & $68 \%-88 \%$ \\
\hline
\end{tabular}

DARCO Hg. Further process optimization tests were conducted to make competitive activated carbon using North Dakota lignite.

\section{CTF Activated Carbon Test}

The activated carbons produced at process optimization conditions of $900^{\circ} \mathrm{C}$, three residence times (30-, 60-, and 90-min), and a char to steam ratio of 5.5:4 were ground to pass through a 325-mesh sieve and injected into the flue gas stream of the EERC's CTF during combustion of Caballo coal to test mercury capture capability of activated carbon in a subbituminous flue gas stream. The PCD through which the flue gas was directed was an ESP. Figure 18 shows percentage of total mercury removal beyond baseline across the ESP by the different activated carbons. The figure shows that activated carbon made at $900^{\circ} \mathrm{C}$ and 30 -min 


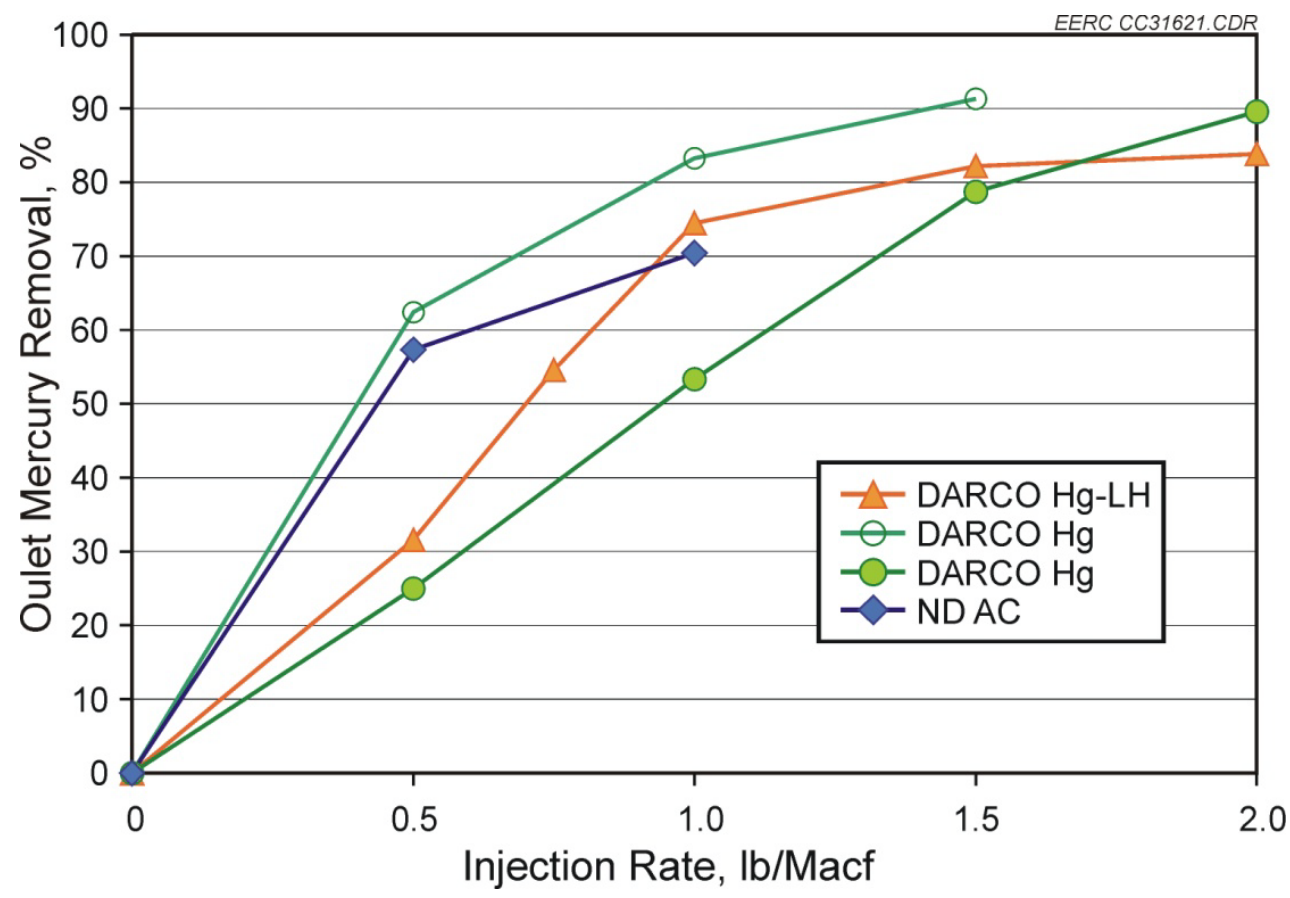

Figure 17. Outlet mercury removal percentage beyond baseline in a slipstream baghouse at a Texas power plant in subbituminous coal-combusted flue gas using Center Mine lignite-derived and DARCO Hg carbon injection as mercury sorbents.

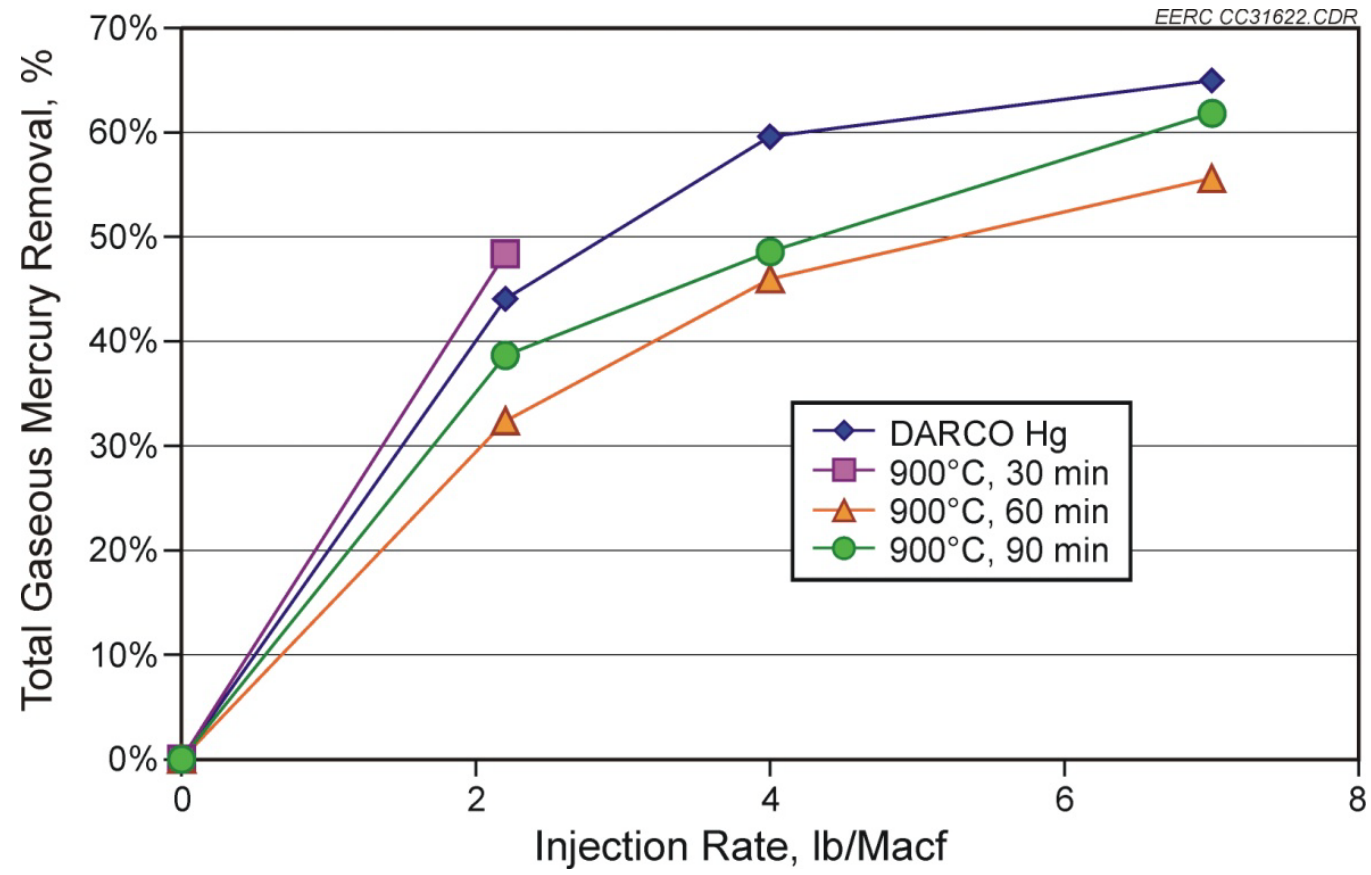

Figure 18. Total gaseous mercury removal percentage beyond baseline in a pilot-scale ESP in using Center Mine lignite-derived and DARCO Hg carbon injection as mercury sorbents (combustion of Caballo coal in the CTF). 
residence time removed $48 \%$ total mercury at an injection rate of about $2.2 \mathrm{lb} / \mathrm{Macf}$. Inconsistent feeding of subsequent rates prevented acquisition of mercury removal rates at higher temperatures. The activated carbon made at $900^{\circ} \mathrm{C}$ and 60 -min residence time removed up to $56 \%$ of total gaseous mercury at an injection rate of $7 \mathrm{lb} /$ Macf.

The figure also clearly shows that activated carbon made at $900^{\circ} \mathrm{C}$ and 90 -min residence time removed up to $62 \%$ total gaseous mercury, which is in the range of the DARCO FGD removal rate of $65 \%$ of total gaseous mercury at the 7-lb/Macf carbon injection rate. Therefore, EERC-produced Center Mine lignite-derived activated carbon made at $900^{\circ} \mathrm{C}$ and 90 -min residence time performed as well as DARCO FGD in terms of mercury removal. The same trend was also observed in the bench-scale mercury capture test performed using activated carbon at $900^{\circ} \mathrm{C}$ (presented in Figures 11 and 13).

Figure 19 shows the variation in the outlet concentration of total mercury in the CTF for different activated carbons injected upstream of the ESP. At the start of each test (i.e., no sorbent injection), the outlet mercury concentration is the lowest for the test injecting activated carbon made at the EERC at $900^{\circ} \mathrm{C}$ and 90 -min residence time, and the outlet mercury concentration is the highest for the test injecting DARCO FGD. Mercury removal is more difficult if the mercury concentration is very low. Even starting with the lowest mercury concentration, activated carbon made at the EERC at $900^{\circ} \mathrm{C}$ and 90 -min residence time was as efficient as DARCO FGD in mercury removal.



Figure 19. Outlet gaseous mercury concentration in a pilot-scale ESP using Center Mine lignitederived and DARCO ${ }^{\circledR} \mathrm{Hg}$ carbon injection as mercury sorbents (combustion of Caballo coal in the CTF). 


\section{CTF Test Using Carbon Activated at $900^{\circ} \mathrm{C}$}

Previous CTF tests confirmed that activated carbon made at $900^{\circ} \mathrm{C}$ and 90 -min residence time was competitive to commercial DARCO FGD for mercury capture. The EERC further investigated mercury capture property of activated carbon made at $900^{\circ} \mathrm{C}$ and 90 -min residence time. Virgin activated carbon, water-washed activated carbon, and enhanced activated carbon, along with DARCO FGD, were tested in the CTF for mercury capture. Figure 20 shows that virgin activated carbon made at $900^{\circ} \mathrm{C}$ and 90 -min residence time attained the highest gaseous mercury removal from flue gas. The other two activated carbons, water-washed and enhanced, were not as good as DARCO FGD for mercury capture. These results were surprising. Upon further examination, it was determined that the water-washed and enhanced activated carbons did not have adequate time to dry prior to injection, leading to inadequate dispersion inside the CTF and compromised active sites on the surface. This led to poorer performance of these two carbons. Despite the inconclusive results regarding the water-washed and enhanced carbon, the results of this CTF test confirmed that activated carbon made at $900^{\circ} \mathrm{C}$, and 90 -min residence time is an equally or more effective product compared to commercial-grade DARCO $\mathrm{Hg}$ for mercury capture.

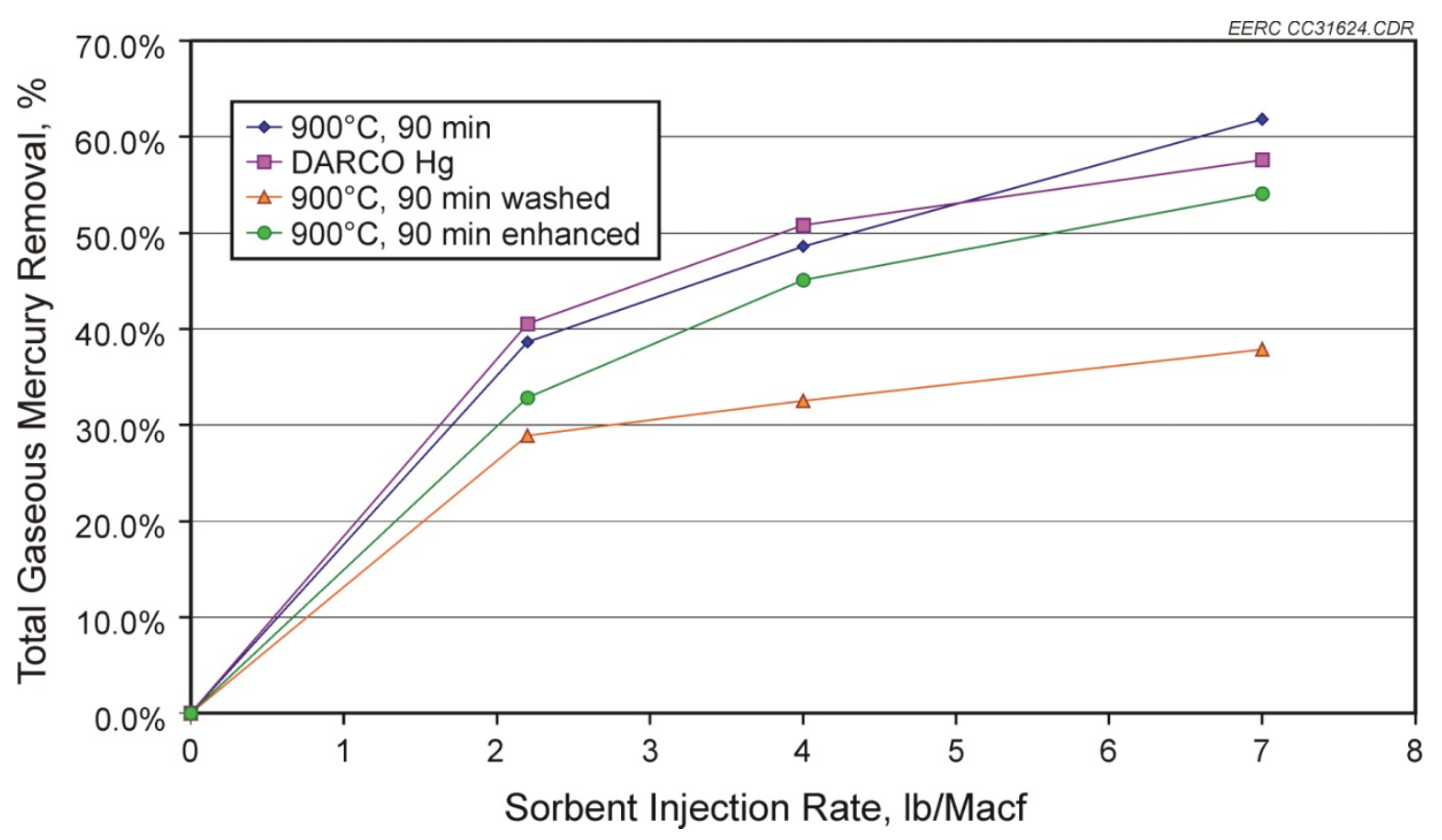

Figure 20. Total gaseous mercury removal percentage beyond baseline in a pilot-scale ESP using Center Mine lignite-derived carbon made at $900^{\circ} \mathrm{C}$ and DARCO $\mathrm{Hg}$ carbon injection as mercury sorbents (combustion of Caballo coal in the CTF). 


\section{Task 3 - Conceptual Design of a Commercial Plant Producing Activated Carbon from Fort Union Lignite}

\section{Process and Plant Design}

Chavond-Barry Engineering Corporation, the design subcontractor, and Envergex, the process design and plant economics consultant, completed a feasibility study for producing activated carbon in a multiple hearth furnace (MHF). A MHF was selected for several reasons. Drying, devolatilizing, and char activation can all be performed within one reactor. Its vertical configuration and countercurrent design are uniquely suited for the small plant area available for the production facility. Flexibility in terms of independent temperature control of each hearth makes it possible to tailor product quality for various end uses. Both granular (higher-value product) and powdered activated carbon (PAC) can be produced.

The main pieces of equipment include the following:

- Wet feed storage

- Hammer mill

- Furnace feed storage

- MHF

- Product cooler

- Bulk product storage

- Roller mill for product grinding

- Final product storage silos

- Pneumatic truck fill station

- MHF process gas combustor and ductwork to power plant

\section{Economic Feasibility Study}

The economic evaluation of the activated carbon plant is based on manufacturing PAC. This product would be sold in bulk and transported by tank trucks. A market analysis for PAC for municipal water treatment plants indicated PAC prices between $\$ 650$ and \$900/ton.

Overall operating costs were calculated and a financing structure developed to provide a simple return on investment calculation. To look at a conservative scenario, calculations were performed with a lower selling price $(\$ 600 /$ ton), reduced production rate, and lower capacity factor. The annual revenue decreased and production cost increased, but the annual return on investment (ROI) was still acceptable.

In summary, process design, equipment selection, and component layout were completed. The product characteristics and technical performance of the activated carbon material produced at the pilot plant show that its quality is superior to competitive products. 


\section{Market Assessment of Lignite-Derived Activated Carbon}

\section{Product Overview}

The activated carbon production plant is targeted to initially produce activated carbon for the water treatment market, which is a commodity market. As the mercury control market develops, the plant is anticipated to switch over to producing an increasing amount of carbon dedicated to mercury control.

The main customer base for the water treatment is municipalities with wastewater treatment plants or drinking water supply plants. The main customer base for the mercury control market will be regulated and nonregulated utility companies that own and operate coal-fired power plants.

\section{Plain Powdered Activated Carbon (PAC)}

The base product that will be manufactured at the plant is PAC.

For the water treatment market, PAC is more versatile than granular activated carbon (GAC) in that the quantity used can be increased or decreased to compensate for input changes. In a PAC application, typically a batch contact is employed. In this contact method, PAC is added to liquid to be treated as a prepared suspension. Once adsorption is complete, the liquid is filtered to remove the spent carbon. Typically the spent carbon is disposed of after a single use. Continuous filtration methods are used with GAC. In this process, the liquid is pumped or allowed to flow by way of gravity through a bed of prepared GAC. Continuous-layer filtration is used primarily for liquid with low levels of impurities or for purification.

Product specification for PAC for water treatment: The standard that is used for product specification is ANSI/AWWA B600, Powdered Activated Carbon (rev. 10/05) issued by the American Water Works Association (11). Some of the main specifications that the product has to meet include i) moisture - less than 8\%, ii) particle-size distribution - 95\% less than 200 mesh, and iii) iodine number - greater than $500 \mathrm{mg} \mathrm{I} / \mathrm{g}$ carbon.

Product specification for PAC for mercury control: Since this is an emerging application, no standards have yet been developed for plain PAC for the mercury control application. Customer specifications may include comparison to a benchmark that has been tested extensively in demonstration projects and that is commercially available from other suppliers. An example of this benchmark is a PAC supplied by Norit Americas Inc. (DARCO Hg). The main specifications for this product include the following: i) molasses decolorizing efficiency - 80 minimum, ii) particle size - 95\% less than 200 mesh, and iii) moisture - less than 8\% (12).

As seen above, the product specifications above for PAC for the water treatment market and for the base PAC for mercury control have similar characteristics and can be easily substituted. 


\section{Impregnated Powdered Activated Carbon (X-PAC)}

Continuing research and development of mercury control technology for coal-fired power plants shows that treating PAC with halogens (impregnated PAC) significantly improves the kinetics of mercury removal and degree of mercury reduction that can be achieved. This is especially the case for applications to power plants that fire coals with low chlorine content (mainly lignite and Powder River Basin subbituminous coals).

It will be cost-effective to incorporate an appropriate halogen impregnation method as part of the overall manufacturing process rather than performing this step separately. There is active ongoing research and development in this subject area. For example, Norit manufactures a product called DARCO Hg-LH which is a powdered activated carbon impregnated with bromine $\left(\mathrm{Br}_{2}\right)$. Another manufacturer, Sorbent Technologies, has a similar product called B-PAC ${ }^{\mathrm{TM}}$. ALSTOM has been performing testing with its own version of halogen-impregnated sorbents called Mer-Clean $^{\mathrm{TM}}$.

Product specification for X-PAC: Since this is an emerging application, no standards have yet been developed. Initial customer specifications may include comparison to a benchmark in pilot-scale or full-scale demonstration tests with respect to mercury removal capability. As indicated above, an example of this benchmark is DARCO Hg-LH, a PAC supplied by Norit Americas Inc. The main specifications for this product include the following: i) molasses decolorizing efficiency - 70 minimum, ii) particle size - 95\% less than 200 mesh, iii) moisture less than $12 \%$, and iv) bromine content - unspecified (13).

\section{Bituminous Coal Applications}

Plain PAC as well as halogen-impregnated PAC has not performed as well in flue gas from bituminous coal firing compared to flue gas from subbituminous or lignite coal firing. One of the reasons hypothesized is the poisoning effect of sulfur species such as $\mathrm{SO}_{2}$ and $\mathrm{SO}_{3}$ in the flue gas. Development of sulfur-tolerant PAC would be a significant breakthrough.

\section{Concrete-Friendly Activated Carbons}

Utilization of fly ash from coal-fired power plants for concrete is one of the ways to increase revenue and avoid ash disposal costs for a coal-fired power plant. The presence of activated carbon in the fly ash makes it unsuitable in many cases for such an application. Concrete-friendly sorbents is another market segment that should be targeted by the activated carbon production plant. Sorbent Technologies has a product called C-PAC in this category.

The most appropriate method and formulation for sorbent(s) for mercury control will be selected and implemented at the time of final design and construction of the plant. It is anticipated that impregnated PAC(s) will be some of the main products of the proposed activated carbon plant. 


\section{Granular Activated Carbon (GAC)}

In addition to the above, the activated carbon plant is capable of producing a portion of its output as GAC. GAC is used in water treatment applications and commands a significantly higher price than PAC. The standard used for product specification for GAC is ANSI/AWWA B604, Granular Activated Carbon (rev. 03/06) issued by the American Water Works Association (14). Some of the main specifications that the product has to meet include i) moisture - less than $8 \%$; ii) particle-size distribution $-0.3 \mathrm{~mm}$ to $2.0 \mathrm{~mm}$ (not more than $15 \%$ of the activated carbon shall be retained on the maximum-specified sieve, and not more than $5 \%$ of the activated carbon shall pass through the minimum-specified sieve); iii) iodine number - greater than $500 \mathrm{mg} \mathrm{I} / \mathrm{g}$ carbon; abrasion resistance - retention of average particle size of GAC should be greater than $70 \%$, as determined by either the stirring abrasion test or Ro-Tap abrasion test; and iv) watersoluble ash content - less than $4 \%$.

GAC has significantly more requirements than PAC and further testing is needed to determine if a suitable quality GAC can be manufactured at the proposed plant.

\section{Industry Overview}

The U.S. market for virgin activated carbon includes GAC and PAC. The industry is further divided into various applications, including liquid-phase applications (water treatment, pharmaceutical, and food and beverage processing) and gas-phase applications (mercury control, air purification, and emission canisters). This analysis focuses on PAC for water treatment and mercury control.

Growth in the water treatment market is expected to remain favorable because of ongoing concerns over water purity (Table 13). Increased water recycling, particularly in municipalities, manufacturing, and electric utilities, will promote demand for activated carbon, since this water must undergo additional treatment. However, the most rapid gains are forecast for pharmaceuticals, where demand will be driven by favorable advancements in production of nutraceuticals, vitamins, and pharmaceuticals (15). Table 13 provides the demand for activated carbon in water treatment by type and product (15). Gains in the future will be fueled by more stringent environmental regulations as well as the need to upgrade aging water and wastewater systems.

The water treatment market for activated carbon is a commodity market. Some of the major U.S. suppliers include Calgon Carbon and Norit. Calgon Carbon offers primarily granular carbons under the CENTAUR and Filtrasorb brand names. Norit offers both granular and powdered activated carbon under the Hydrodarco ${ }^{\circledR}$ and Norit brand names. Other distributors also offer carbons by importing them to the United States, particularly from China. Typical prices for PAC in this market are in the range of $\$ 650$ to $\$ 900 /$ ton.

Although currently an emerging market for activated carbon, gas-phase applications will offer more rapid gains in the coming years than the liquid-phase segment. One area of expansion is in the use of activated carbon in air filters and emission canisters. 
Table 13. Activated Carbon Demand in Water Treatment (million pounds) ${ }^{1}$

\begin{tabular}{lccccc}
\hline & 1992 & 1996 & 2001 & 2006 & 2011 \\
\hline AC Demand in Water Treatment & 102 & 133 & 157 & 179 & 208 \\
By Type: & & & & & \\
Drinking Water & 54 & 73 & 89 & 105 & 126 \\
Wastewater and Sewage & 40 & 50 & 55 & 58 & 62 \\
Groundwater & 8 & 10 & 13 & 16 & 20 \\
By Product: & & & & & \\
Granular & 45 & 58 & 69 & 80 & 95 \\
Powdered & 57 & 75 & 88 & 99 & 113 \\
\hline${ }^{1}$ Source is the Freedonia Report (15). & & & & &
\end{tabular}

Especially strong gains are forecast for automotive emission canisters based on the implementation of stricter EPA guidelines regarding evaporative losses. The new regulations, which went into effect with 2000 model year cars, have necessitated the use of larger capacity canisters, which is increasing activated carbon usage per unit. More importantly, new regulations requiring light or medium trucks to be outfitted with these units are being phased in over the next 6 years (15). Such vehicles were previously exempt from these regulations. MeadWestvaco is the market leader in this application.

Another area of expansion in the gas-phase application is in mercury control applications for coal-fired power plants. That is a particular focus area for this project. The mercury control market is an emerging market, anticipated to increase rapidly in the near future. New legislation curbing mercury emissions from power plants will be a source of substantial increase in demand for activated carbon.

\section{Demand for Activated Carbon}

Available data indicate that apparent U.S. consumption of activated carbon rose between 2003 and 2005 for an increase of $12.8 \%$ (16). It appears that the demand is growing. As part of the International Trade Commission (ITC) antidumping investigation, U.S. producers, Chinese exporters, and U.S. importers of activated carbon were interviewed on a variety of trade topics. When asked if demand for activated carbon had changed since 2002, major producers and importers responded that demand had increased between 2003 and 2005. Two importers specifically stated that demand has been growing consistently at 3\% to $5 \%$ per year.

Historical data on the demand for activated carbon place a total market value of \$390 million in 2001 as found in Table 14. In addition to virgin activated carbon demand valued at \$280 million, the US market encompasses off-site regeneration revenues and related services amounting to $\$ 110$ million. The U.S. activated carbon industry comprises about 20 firms. The top three suppliers-Calgon Carbon, MeadWestvaco, and Norit Americas-accounted for $75 \%$ of total sales in 2001. 
Table 14. Activated Carbon Demand ${ }^{1}$

\begin{tabular}{lcccc}
\hline & \multicolumn{5}{c}{ Annual Growth } \\
\hline Item & 1996 & 2001 & 2006 & 2011 \\
\hline Gross Domestic Product (GDP), bil \$ & 7813 & 10,208 & 13,100 & 16,800 \\
\$ Activated Carbon/mil, \$GDP & 32.4 & 27.4 & 25.3 & 23.6 \\
Activated Carbon Demand, mil \$ & 253 & 280 & 332 & 397 \\
Price, \$/lb & $\$ 0.76$ & $\$ 0.72$ & $\$ 0.74$ & $\$ 0.76$ \\
Activated Carbon Demand, mil lb & 334 & 390 & 450 & 525 \\
Liquid-Phase Applications, mil lb & 272 & 320 & 365 & 420 \\
Gas-Phase Applications, mil lb & 62 & 70 & 85 & 105 \\
Net Exports, mil lb & -8 & -2 & -5 & -10 \\
Activated Carbon Shipments, mil lb & 326 & 388 & 445 & 515 \\
\hline${ }^{1}$ Source: Freedonia Report (15). & & & &
\end{tabular}

\section{Market Segments and Identification of Market Opportunities}

The two market segments chosen as the focus of this analysis are mercury control and water treatment. The water treatment market is an existing market. The PAC under development is suitable for both applications and could be licensed for either water treatment or mercury control applications. The EERC, which houses the Center for Air Toxic Metals $\left(\mathrm{CATM}^{\circledR}\right)$, has institutional knowledge of mercury control, and Envergex LLC personnel have developed methods and sorbents for mercury control (17). EPA regulations are expected that will move the demand toward rapid growth.

\section{Mercury Control}

One use of activated carbon that may increase greatly in the future is the control of mercury emissions from coal-fired power plants. In March 2005, the U.S. Environmental Protection Agency (EPA) issued the Clean Air Mercury Rule to cap and reduce mercury emissions from coal-fired power plants. It mandates a 70\% reduction in mercury from coal-fired power plant flue gas by 2010 (18). When implemented, this regulation will reduce mercury emissions by nearly $70 \%$, and many states are also enacting their own limits for mercury emissions. To meet the final mercury emissions cap, mercury control technologies will be needed. While still primarily in the demonstration stage of development, injection of PAC into the flue gas from coal-fired plants has, to this point, shown the most promise for meeting the mercury emissions cap.

The value of the market opportunity, injection of PAC as a leading technology for mercury control, is estimated between $\$ 100$ and $\$ 500$ million annually in the United States according to Calgon Carbon (19).

\section{Activated Carbon Injection Technology for Mercury Control}

In activated carbon injection technology, PAC sorbent is injected into the flue gas at a location in the duct upstream of the particulate collection device, such as an ESP or fabric filter. 
The PAC sorbent adsorbs the mercury from the flue gas and is collected with the remainder of the ash in the particulate filter. Greater mercury removal is obtained with a fabric filter compared to an ESP because of the increased sorbent-gas contact in the filter cake on the surface of the filter bags. This approach is shown schematically in Figure 21.

The performance of activated carbon is related to its physical and chemical characteristics. Generally, the physical properties of interest are surface area, molasses number (related to the proportion of large transport pores), pore-size distribution, and particle-size distribution. The adsorption process also has a chemical component - elemental mercury in the flue gas has to be oxidized before it can be adsorbed on the carbon surface. Consequently, flue gas composition, in particular the amount of halogen compounds present, either limits or enhances the performance of activated carbon with respect to mercury capture.

The ability of PAC to capture mercury is also dependent on other flue gas parameters such as the flue gas temperature. While higher temperatures favor the oxidation step, a necessary precursor to adsorption and capture, lower temperatures favor the adsorption step. The selection and the properties of the activated carbon for a given mercury control application should take into account the total concentration of Hg, the flue gas composition, the method of particulate capture (ESP, fabric filter, or dry scrubber) and the total contact time available for the sorbent and the flue gas.

At present, activated carbon injection is the most widely studied of the mercury-specific control technologies for coal-fired power plants and shows the potential to achieve moderate-to-

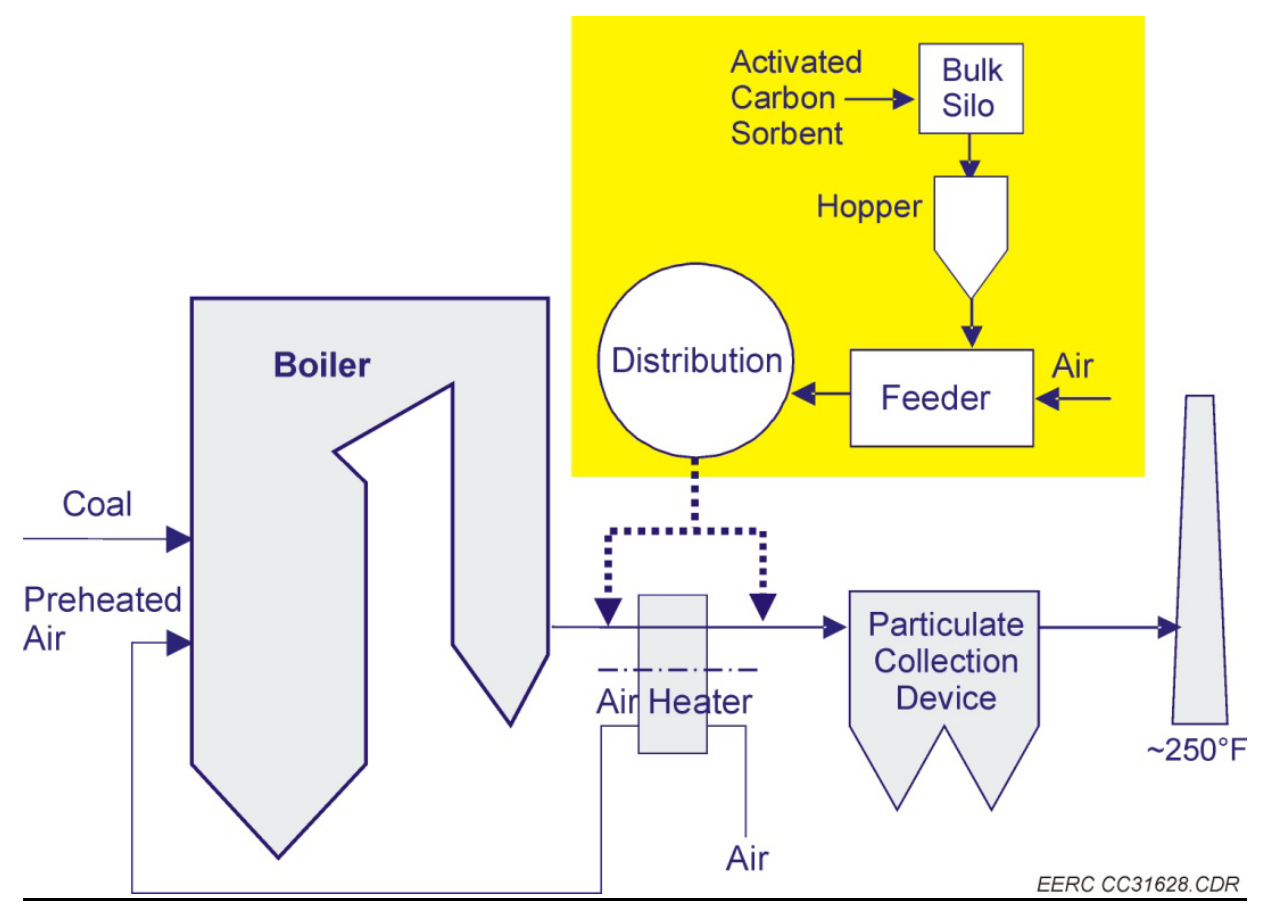

Figure 21. Activated carbon injection technology for mercury control in coal-fired power plants. 
high levels of mercury control. Several demonstration tests at full-scale are increasing the experience level with this technology, enabling new developments and reducing the costs (e.g., lowered sorbent consumption). This is allowing the utility industry to begin adopting this technology with the recognition that it is cost-effective, improves their environmental performance, and has minimal impacts on their overall operations.

\section{New Coal-Fired Power Plants Application for Mercury Control}

A June 23, 2006, press release is indicative of the emerging mercury control market (20). ADA-ES was awarded a contract to supply a mercury emission control system for a new power plant being built in Arkansas. LS Power is building a new plant that will produce 680 MWe (gross) of power and burn subbituminous coal from the Powder River Basin area of Wyoming. The mercury emission control system would utilize PAC to remove mercury from the flue gas of the power plant. ADA-ES anticipates delivery of the system during the fourth quarter of 2007. "The mercury control marketplace continues to develop at a rapid pace, as evidenced by the contracts we have been awarded covering seven units so far in 2006," said Dr. Michael Durham, President of ADA-ES. "We expect additional contracts to be granted later this year based upon the large number of proposal requests for this technology to help utilities meet the new mercury emissions regulations being promulgated by various individual states as well as the federal government.”

All new coal-fired power plants are being required to control mercury to some degree, typically in the range of $85 \%$ to $90 \%$ reduction from what is entering the combustor with the coal. Activated carbon injection is being specified as the best available control technology for these plants. The minimal additional cost for mercury control relative to the cost of the total new coal-fired power plant is facilitating the adoption of this technology.

The other important point to note is that there is resurgence in the use of coal for electric power generation. With the dramatic increase in the cost of natural gas (from about \$2.5/MMBtu in 2000 to up to $\$ 13 /$ MMBtu in 2006), coal firing is proving to be a competitive alternative in spite of its higher capital cost and increased lead times for construction and coming online. The following figures demonstrate the projected capacity additions in the next few years (Figure 22) and the geographical distribution of these projected additions (Figure 23) (21). A total of $93 \mathrm{GW}$ at 153 not-yet-built coal-fired plants are proposed through 2015. With a projected consumption of 100 to 500 tons of activated carbon per $100 \mathrm{MW}$, an average of 300,000 tons/yr additional demand may result from the construction of this coal-fired power generation capacity. While the proposals to build these plants will not all go forward for various reasons, a significant portion will be built. In summary, the new coal-fired plants represent a solid market for the application of activated carbon sorbent for mercury control with a projected demand that will represent a significant increase over the current projection of 120,000 tons (240 million pounds) by 2011 (15) and will require the construction of new activated carbon production capacity. 


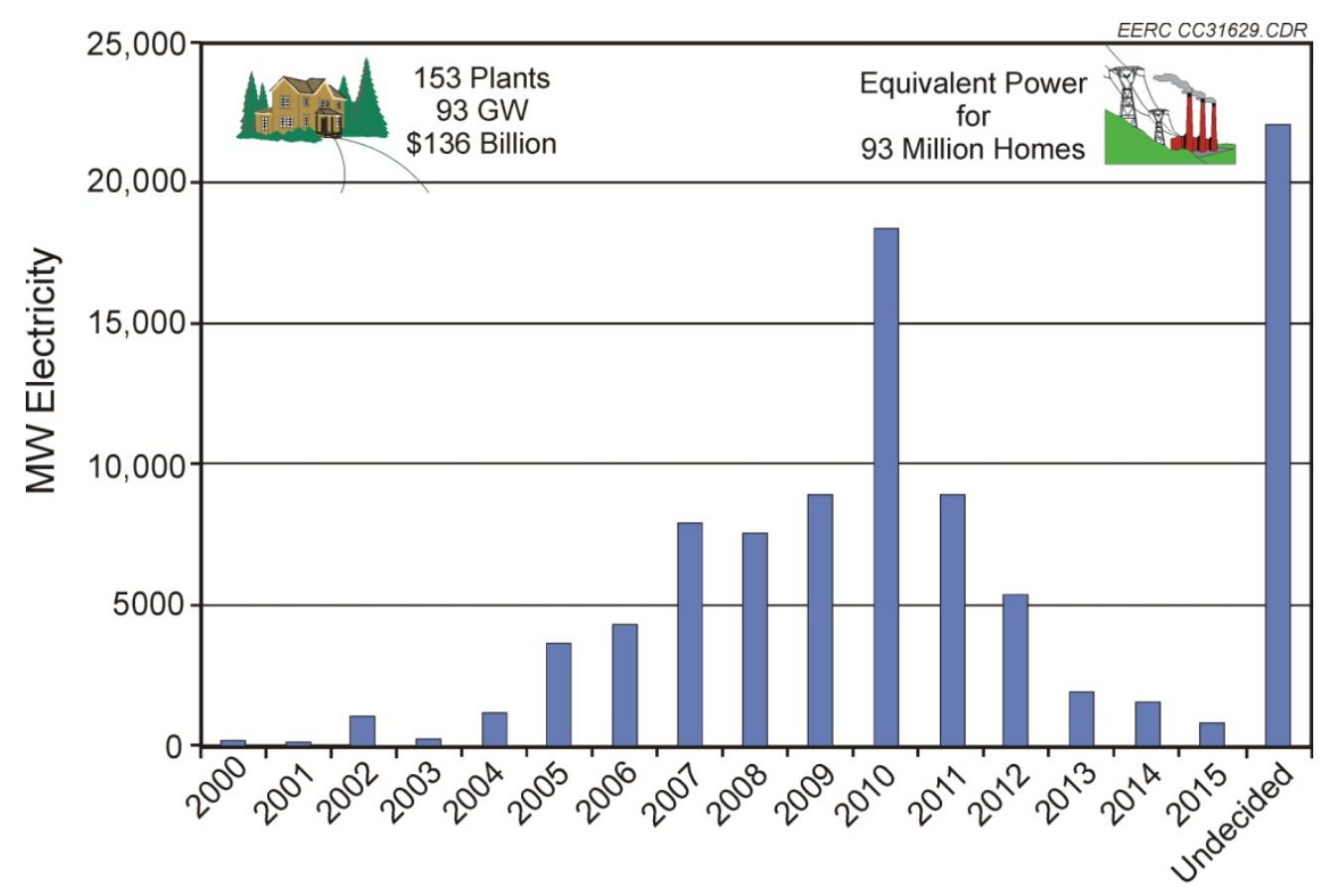

Figure 22. Proposed new coal-fired electric power generation capacity (21).

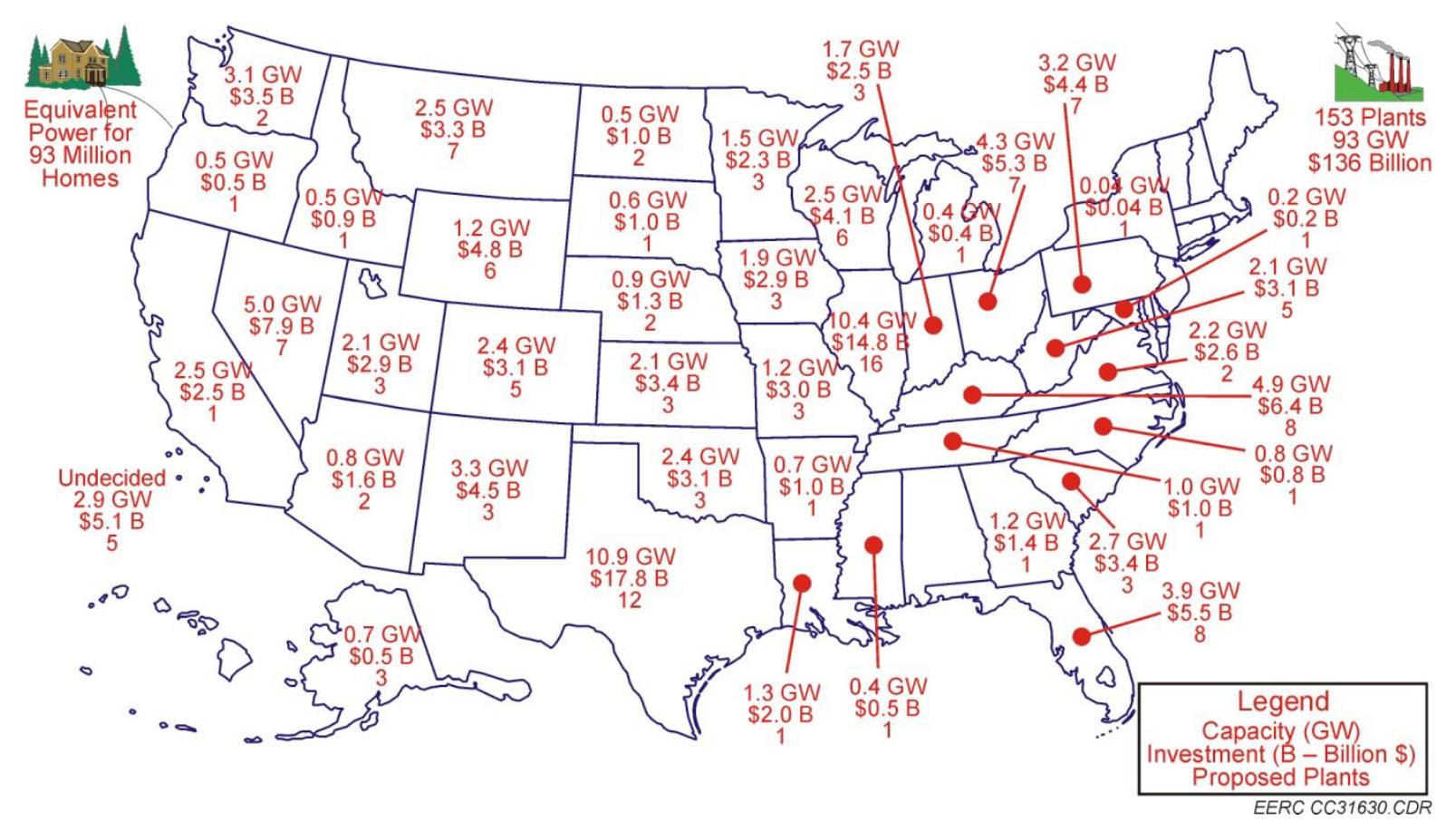

Figure 23. Geographical distribution of new coal-fired electric power generation capacity (21). 


\section{Existing Coal-Fired Power Plants Application for Mercury Control}

Mercury control for existing coal-fired power plants is also an emerging application for activated carbon injection being driven by federal and state legislation to curb mercury emissions. There are about 1180 coal-fired plants in the United States with product capacity greater than 100 MWe, representing approximately 315 GWe in total.

While the federal regulations for mercury emissions, which are to be implemented in two phases (by 2010 and by 2018), will necessitate the use of activated carbon for mercury control in some plants, the primary driver for the adoption of carbon injection technology is going to be driven by state regulations, many of which are more stringent and will need to be met on an earlier schedule than the federal regulation. Tables 15 and 16 show the states that have already promulgated mercury control legislation or are planning to impose standards more stringent than the federal standards.

It is anticipated that the market for activated carbon injection for mercury control at existing coal-fired power plants will develop in the following manner: 5\% by 2010, 20\% by 2015 , and $40 \%$ by 2018 . With these assumptions, we can expect the activated carbon demand for this market to be about 50,000 tons by 2010 and about 200,000 tons by 2015. This is in addition to the new coal-fired capacity discussed in the earlier section.

In summary, an expected robust demand for activated carbon for mercury control in the next decade will represent a new market for the use of activated carbon. The size of this market is expected to more than double the current demand for activated carbon of about 220,000 tons.

\section{Water Treatment}

The global market for drinking water and wastewater disinfection is estimated at $\$ 3.0$ billion over the next 10 years. Today, more than 16,000 publicly owned wastewater treatment plants operate in the United States and its territories. The McIlvaine Company maintains a database of the characteristics and contacts of each through a subscription-only database. According to McIlvaine, 4000 plants represent $80 \%$ of the total treatment facility capacity, and the remaining 12,000 plants represent $20 \%$ of the total treatment capacity. Those facilities are in the smaller cities in the United States (22).

Table 15. States with Aggressive Mercury Emission Regulations as of 2006

\begin{tabular}{lcc}
\hline Final Hg Action & Pending Hg Regulatory Action & Legislative Action \\
\hline Connecticut & Indiana & Ohio \\
New Jersey & Virginia & New Hampshire \\
Wisconsin & North Carolina & Minnesota \\
Massachusetts & Michigan & Illinois \\
& STAPPA*/ALAPCO** & New York \\
& Montana \\
& & Maryland \\
\hline
\end{tabular}

* State and Territorial Air Pollution Program Administrators.

** Association of Local Air Pollution Control Officials. 
Table 16. States with Plans for Aggressive Mercury Emission Regulations

\begin{tabular}{|c|c|c|c|c|}
\hline & State & $\begin{array}{c}\text { Rules or Legislation - Adopted or } \\
\text { Proposed }\end{array}$ & $\begin{array}{c}\text { Participation in National } \\
\text { Trading Program }\end{array}$ & $\begin{array}{l}\text { Allocation of } \\
\text { Allowances }\end{array}$ \\
\hline \multirow[t]{6}{*}{ Region 1} & Connecticut & $\begin{array}{l}90 \% \text { reduction or } 0.6 \mathrm{lb} / \mathrm{Tbtuby} 07 / 01 / 2008 \text {. More } \\
\text { stringent limits afer07/01/2012 }\end{array}$ & No & No \\
\hline & Maine & $\begin{array}{l}\text { All facilities } 50 \mathrm{lb} / \mathrm{y} \text {; proposed } 35 \mathrm{lb} / \mathrm{y} \text { by } 2007 \text { and } \\
25 \mathrm{lb} / \mathrm{yr} \text { by } 2010\end{array}$ & No & \\
\hline & Massachusetts & $\begin{array}{l}85 \% \text { capture or } 0.0075 \mathrm{lb} / \mathrm{GWh} \text { by } 1 / 1 / 2008 \text { and } \\
95 \% \text { capture or } 0.0025 \mathrm{lb} / \mathrm{GWh} \text { by } 10 / 1 / 2012\end{array}$ & No & \\
\hline & New Hampshire & $\begin{array}{l}\text { Legislation passed House and Senate, signed by } \\
\text { Govemor. Calls for } 80 \% \text { reduction of mercury } \\
\text { emissions from coal-burning power plants through } \\
\text { installation of scrubber technology no later than } \\
7 / 1 / 2013 \text {. Emission credits for } \mathrm{SO}_{2} \text { for early } \\
\text { mercury reductions. }\end{array}$ & No & \\
\hline & Rhode Island & No budget under CAMR & Not required & \\
\hline & Vermont & No budget under CAMR & Not required & \\
\hline \multirow[t]{2}{*}{ Region 2} & New Jersey & $\begin{array}{l}\text { Adopted rule requires control efficiency of } 90 \% \text { or } \\
3 \mathrm{mg} / \mathrm{MWhr} \text { by } 12 / 15 / 2007 \text {, for coal-fired boilers of } \\
\text { any size. A multi-pollutant approach can reduce } \\
\text { the initial reduction required and extend } \\
\text { compliance to } 12 / 15 / 2012 \text {. }\end{array}$ & & \\
\hline & New York & $\begin{array}{l}\text { On 5/25/06, the Governor announced a plan: } \\
\text { Applicability will be the same as CAMR; } \\
\text { allocations will be distributed as facilitywide caps, } \\
\text { which are applicable } 2010-12 / 31 / 14 \text { and } \\
\text { represent a } 50 \% \text { reduction in emissions from the } \\
1999 \text { ICR data collection. Beginning in } 2015 \\
\text { based emission limits will be implemented and } \\
\text { represent a } 90 \% \text { reduction in emissions from the } \\
1999 \text { ICR data collection. Emissions below } \\
\text { facilitywide caps will be prohibited from trading or } \\
\text { selling. Regulation is in preliminary stage, } \\
\text { stakeholder meetings planned. }\end{array}$ & No & \\
\hline \multirow[t]{5}{*}{ Region 3} & Delaware & $\begin{array}{l}\text { Governor's proposal for stakeholder consideration } \\
\text { is the adoption of a more stringent state rule that } \\
\text { would not include banking and trading. }\end{array}$ & $\begin{array}{l}\text { No. Proposal does not allow } \\
\text { interstate trading }\end{array}$ & \\
\hline & Maryland & $\begin{array}{l}\text { Healthy Air Act of } 4 / 6 / 2006 \text {. Phase I reduction of } \\
80 \% \text { by } 2010 ; \text { Phase II reduction of } 90 \% \text { by } 2013 \text {. }\end{array}$ & No. & \\
\hline & Pennsylvania & $\begin{array}{l}\text { On May } 17,2006, \text { the Environmental Quality } \\
\text { Board approved the rule for a } 60 \text {-day public } \\
\text { comment period with } 3 \text { public hearings. The } \\
\text { proposed rule will require an } 80 \% \text { reduction in } \\
\text { mercury emissions by } 2010 \text { and a } 90 \% \text { reduction } \\
\text { by } 2015 \text {. Legislation introduced in April } 2006 \\
\text { requires compliance with CAMR. DEP accepted a } \\
\text { citizen petition requesting a state rule more } \\
\text { stringent than CAMR. }\end{array}$ & $\begin{array}{l}\text { No. Proposal does not allow } \\
\text { interstate trading }\end{array}$ & \\
\hline & Virginia & $\begin{array}{l}\text { Governor signed Clean Smokestacks Legislation, } \\
\text { effective } 7 / 1 / 2006 \text {. Requires adoption of CAMR } \\
\text { and state-specific rule. Largest operator must } \\
\text { meet reductions by } 2015 \text { and cannot purchase } \\
\text { allowances to comply, but may sell excess credits. } \\
\text { Second largest operator may use emission credits } \\
\text { generated from other units under common } \\
\text { ownership that are within } 200 \mathrm{~km} \text { of VA's border. } \\
\text { Units within a nonattainment area cannot } \\
\text { purchase credits to comply. However, credits } \\
\text { generated at units under common ownership } \\
\text { within } 200 \mathrm{~km} \text { of VA's border may be used to } \\
\text { comply with the state rule. }\end{array}$ & $\begin{array}{l}\text { Limited trading for largest units. } \\
\text { Allowed for smaller units }\end{array}$ & $\begin{array}{l}\text { New source set aside of } 5 \% \text { for } \\
\text { the first } 5 \text { years of program, } \\
\text { then } 2 \% \text { thereafter. }\end{array}$ \\
\hline & West Virginia & CAMR-EPA model rule & Yes & \\
\hline Region 4 & Alabama & CAMR-EPA model rule & Yes & \\
\hline
\end{tabular}

Continued... 
Table 16. States with Plans for Aggressive Mercury Emission Regulations (continued)

\begin{tabular}{|c|c|c|c|c|}
\hline & State & $\begin{array}{c}\text { Rules or Legislation - Adopted or } \\
\text { Proposed }\end{array}$ & \begin{tabular}{|c} 
Participation in National \\
Trading Program
\end{tabular} & $\begin{array}{l}\text { Allocation of } \\
\text { Allowances }\end{array}$ \\
\hline & Tennessee & Proposed rule that would adopt EPA model rule. & & \\
\hline \multirow[t]{6}{*}{ Region 5} & Illinois & $\begin{array}{l}\text { Governer's proposal (1/06) requests Illinois EPA to } \\
\text { develop rules for a two-phase reduction approach. } \\
90 \% \text { reduction with intrastate averaging by } 6 / 09 ; \\
75 \% \text { individual plant reduction by } 6 / 09 ; 90 \% \\
\text { individual plant reduction by end of } 2012 .\end{array}$ & & \\
\hline & Indiana & $\begin{array}{l}\text { Citizen petition for } 90 \% \text { control under review. } \\
\text { Stakeholder group evaluating three options: Adopt } \\
\text { CAMR, modify CAMR, or require } 90 \% \text { capture with } \\
\text { no trading and } 2010 \text { compliance. }\end{array}$ & & \\
\hline & Michigan & $\begin{array}{l}\text { 4/17/2006, Governor announced proposal to } \\
\text { reduce mercury utility emissions beyond CAMR. } \\
\text { The first phase would use the reductions from the } \\
\text { CAMR and other federal programs by } 2010 \text {. The } \\
\text { second phase would go beyond, for a } 90 \% \text { reduction } \\
\text { by } 2015 \text {. System-wide averaging would be allowed } \\
\text { as long as hotspots do not result. }\end{array}$ & & \\
\hline & Minnesota & $\begin{array}{l}\text { Mercury Emissions Reduction Act of } 2006 \text { calls for: } \\
\text { - } 90 \% \text { reduction (totaling } 1200 \mathrm{lb} \text { ) of annual } \mathrm{Hg} \\
\text { emissions at state's three largest coal-fired power } \\
\text { plants; } \\
\text { - State to exceed } 70 \% \text { reduction in } \mathrm{Hg} \text { emissions } \\
\text { well before } 2018 \text { federal deadline; } \\
\text { - Review of } \mathrm{Hg} \text { reduction plans for feasibility by } \\
\text { Minn. Pollution Control Agency (MPCA); and } \\
\text { - Review of } \mathrm{Hg} \text { reduction plans by Minn. Public } \\
\text { Utilities Commission to ensure cost to ratepayers } \\
\text { is not excessive. }\end{array}$ & & \\
\hline & Ohio & Plan to adopt EPA model rule. & Yes & \\
\hline & Wisconsin & $\begin{array}{l}\text { October } 2004 \text { adopted rule requires } 40 \% \\
\text { reduction by } 2010 \text { and } 75 \% \text { reduction by } 2015 . \\
\text { Reductions from a baseline determined from } \\
\text { mercury in coal. True-up to CAMR reduction levels } \\
\text { and schedule required in the state rule. }\end{array}$ & $\begin{array}{l}\text { CCPI project - WE Energies } \\
\text { Presque Isle }\end{array}$ & $\begin{array}{l}\text { Recently two construction } \\
\text { permits issued. Wisconsin } \\
\text { Public Service Corporation's } \\
\text { Weston Power Plant in } \\
\text { Rothschild a } 500 \text {-MW boiler } \\
\text { burning subbituminous coal } \\
\text { must achieve } 83 \% \text { mercury } \\
\text { control. The second permit } \\
\text { requires } 90 \% \text { mercury control } \\
\text { at WE Energies Elm Road } \\
\text { Generating Station in Oak } \\
\text { Creek of two } 615 \text {-MW boilers } \\
\text { burning bituminous coal. }\end{array}$ \\
\hline \multirow[t]{5}{*}{ Region 6} & Arkansas & Reviewing the model rule as well as alternatives. & $\begin{array}{l}\text { May participate in interstate } \\
\text { trading }\end{array}$ & \\
\hline & Louisiana & $\begin{array}{l}\text { Will propose to adopt EPA model rule on June } 20 \text {, } \\
2006 \text {. }\end{array}$ & Yes & \\
\hline & New Mexico & Plan to adopt EPA model rule & $\begin{array}{l}\text { Consideration being given to } \\
\text { not participating in interstate } \\
\text { trading. }\end{array}$ & \\
\hline & Oklahoma & $\begin{array}{l}\text { Plan to adopt EPA model rule, modify EPA model } \\
\text { rule or adopt STAPPANALAPCO model rule. Initial } \\
\text { hearings for comments in April } 2006\end{array}$ & & \\
\hline & Texas & Plan to adopt EPA model rule & & \\
\hline \multirow[t]{4}{*}{ Region 7} & lowa & Plan to adopt EPA model rule & & \\
\hline & Kansas & Plan to adopt EPA model rule & & \\
\hline & Missouri & Plan to adopt EPA model rule & & \\
\hline & Nebraska & Plan to adopt EPA model rule & & \\
\hline Region 8 & Colorado & $\begin{array}{l}\text { Proposed rule that would adopt the EPA model } \\
\text { rule with administrative modifications. }\end{array}$ & Yes & \\
\hline
\end{tabular}


In December 2005, the U.S. EPA set stringent limits on the by-products created by the chlorination of drinking water (23). GAC filtration is a leading cost-effective solution. Perchlorate, an oxidant in rocket fuel, is a source of groundwater contamination throughout the United States. Perchlorate removal from drinking water could potentially be required in 28 states. Calgon Carbon is established in this market with an estimated 70\% market share. Methyl tertiary-butyl ether (MTBE), an octane booster in gasoline, has contaminated aquifers nationwide and will require remediation. Experts have projected the value of that market to range from $\$ 2.0$ billion to $\$ 12.0$ billion, but timing will depend on future regulatory limits on MTBE in drinking water. Calgon Carbon offers activated carbon and biological solutions for MTBE removal. Additional opportunities in drinking water purification include removal of metals, such as arsenic.

Perhaps a logical area to consider as a regional water treatment market would be to follow all or part of EPA's Region 8, which includes Colorado, Montana, North Dakota, South Dakota, Utah, and Wyoming. Neighboring Minnesota is part of Region 7, along with Illinois, Indiana, Michigan, Ohio, and Wisconsin.

State contacts are obtainable through the American Water Works Association (AWAA) and its Web site www.awaaorg. In regard to information about drinking water and technologies, the state contact in North Dakota is Larry Thelan. He indicates that activated carbon is indeed utilized in many municipal facilities, but specific details need to be obtained directly with each facility and he felt that would likely be the case in other states as well (24).

\section{Competitive Overview}

In addition to virgin activated carbon demand valued at \$280 million, the U.S. market encompasses off-site regeneration revenues and related services amounting to $\$ 110$ million, resulting in a total market value of $\$ 390$ million in 2001 (15). The U.S. activated carbon industry comprises about 20 firms. The top three suppliers—Calgon Carbon, MeadWestvaco, and Noritaccounted for $75 \%$ of total sales in 2001 (15).

Calgon Carbon is the largest supplier of activated carbon in the world, with a global market share of about 15 percent as of 2001. The company has a presence in the United States, Western Europe, and Japan. Bituminous coal is a major raw material for the company's activated carbon. In addition to the U.S. production capacity for virgin activated carbon, Calgon Carbon maintains activated carbon processing and regeneration facilities in Western Europe and the Asia/Pacific region. In Western Europe, the company operates through its Chemviron Carbon, a subsidiary in Belgium, which has activated carbon plants in both Feluy, Belgium, and Grays, United Kingdom. In the Asia/Pacific region, Calgon Carbon participates in the activated carbon market through its Calgon Far East Company Limited (Japan) subsidiary, located in Fukui, Fukui Perfecture, Japan.

Norit held a global market share of approximately 11\% in 2001 (15). Norit produces activated carbon through operations in North America and Western Europe. In Western Europe, Norit operates three activated carbon production facilities in Klazienaveen and Zaandam, the 
Netherlands; and Glasgow, United Kingdom. In addition to the production of virgin activated carbon, the Zaandam facility houses regeneration operations. Norit is also involved in the regeneration of activated carbon through a joint venture with Bristol Water Holdings (UK). The joint venture, Purton Carbons Limited (UK), operates a reactivation plant in Purton, United Kingdom.

Norit Americas Inc., headquartered in Marshall, Texas, a wholly owned subsidiary of Norit N.V. of the Netherlands, a world leader in purification technologies established in 1918. Norit is the world's largest producer of PAC and related services. Norit Americas has provided purification solutions since the early 1920s from its headquarters and activated carbon manufacturing facility in Marshall, Texas, and manufacturing and reactivation facilities in Pryor, Oklahoma.

MeadWestvaco holds a global market share of approximately $7 \%$ and was formed by the merger of Mead and Westvaco (Freedonia). Motor vehicle emission canisters account for a large portion of the company's activated carbon sales. MeadWestvaco produces both GAC and PAC at two plants in the United States, located in Covington, Virginia, and Wickliffe, Kentucky.

\section{New Product Development - Mercury Control}

Listings of project development in the area of activated carbon injection are available through the U.S. DOE National Energy Technology Laboratory (NETL) (25). NETL managed the largest funded research program in the United States on the development and demonstration of cost-effective mercury measurement and control technologies for the U.S. coal-fired electricity-generating industry. NETL's research and development program goal is to develop more effective control options in anticipation of upcoming regulations. Field projects and their status are available through NETL, and a list of plants where activated carbon injection demonstrations have been conducted is shown in Table 17.

ALSTOM Power, Inc., is a participant in the DOE/NETL-sponsored program to demonstrate Mer-Cure ${ }^{\mathrm{TM}}$, one of ALSTOM's mercury control technologies for coal-fired boilers. Mer-Cure ${ }^{\mathrm{TM}}$ utilizes a small amount of Mer-Clean ${ }^{\mathrm{TM}}$ sorbent that is injected into the flue gas stream for oxidation and adsorption of gaseous mercury. Mer-Clean sorbents are carbon-based and prepared with chemical additives that promote oxidation and capture of mercury. Mer-Cure is unique in that the sorbent is injected into an environment where the mercury capture kinetics are accelerated (26).

One company that has developed a successful niche in activated carbon injection is ADAES, Inc. It is planning activated carbon production capacity by 2010, and it is developing mercury sorbents to coal-fired power utilities. As of summer 2006, it had around 20 full-scale demonstrations conducted with third parties at power plants. Norit is now also offering its newest commercial product, DARCO Hg-LH, which was designed to control mercury from power plants that burn western coals such as those from the Powder River Basin and lignite. The LH (for lowhalogen coals) carbon has been proven on a number of different western coals in full-scale tests. ADA-ES, Inc., has licensed the patent-pending TOXECON II ${ }^{\mathrm{TM}}$ mercury removal process from 
Table 17. List of Plants Where Activated Carbon Injection Has Been Demonstrated

\begin{tabular}{|c|c|c|c|c|c|}
\hline Plant Name & State & $\begin{array}{l}\text { Coal Type and } \\
\text { Controls }^{1}\end{array}$ & Plant Name & State & $\begin{array}{c}\text { Coal Type and } \\
\text { Controls }^{1} \\
\end{array}$ \\
\hline Independence & AR & Bit (TOX) & Corette & MT & PRB \\
\hline Gaston & $\mathrm{AL}$ & $\mathrm{LS}_{-\mathrm{Bit}^{2}}\left(\mathrm{FF}^{3}\right)$ & Lee 1 & NC & Bit (ESP) \\
\hline Gaston & $\mathrm{AL}$ & LS-Bit $\left(\mathrm{H}-\mathrm{ESP}^{4}\right)$ & Lee 3 & $\mathrm{NC}$ & Bit \\
\hline Arapahoe & $\mathrm{CO}$ & Subbit $^{5}(\mathrm{FF})$ & Cliffside Station & $\mathrm{NC}$ & Bit (H-ESP) \\
\hline Yates 1 & GA & Bit (ESP/FGD $\left.{ }^{6}\right)$ & Buck Station & $\mathrm{NC}$ & Bit (H-ESP) \\
\hline Yates 2 & GA & Bit (ESP) & Antelope Valley & ND & Lignite (SDA $\left.{ }^{7} / \mathrm{FF}\right)$ \\
\hline Council Bluffs 2 & IA & PRB (H-ESP) & Coal Creek & ND & Lignite (C-ESP) \\
\hline Louisa & IA & PRB (H-ESP) & Leland Olds & ND & Lignite (C-ESP) \\
\hline Abbott & IL & HHS-Bit (C-ESP) & Milton R. Young & ND & Lignite (ESP/FGD) \\
\hline Crawford & IL & Subbit (ESP) & Stanton 1 & ND & Subbit (C-ESP) \\
\hline Will County & IL & Subbit (H-ESP) & Stanton 10 & ND & Lignite (SDA/FF) \\
\hline Holcomb & $\mathrm{KS}$ & $\mathrm{PRB}^{8}(\mathrm{SDA} / \mathrm{FF})$ & Conesville & $\mathrm{OH}$ & $\mathrm{HS}-\mathrm{Bit}^{2}$ (ESP/FGD) \\
\hline Brayton Point & MA & LS-Bit (C-ESP) & Gavin & $\mathrm{OH}$ & Bit $\left(\mathrm{TOX}^{9}\right)$ \\
\hline Salem Harbor & MA & LS-SA Bit ${ }^{10}$ (C-ESP) & Lausche & $\mathrm{OH}$ & PRB (H-ESP) \\
\hline DTE Monroe & MI & PRB/Bit (ESP) & Miami Fort 6 & $\mathrm{OH}$ & Bit (H-ESP) \\
\hline Endicott & MI & Bit (C-ESP/FGD) & Portland & PA & Bit \\
\hline Presque Isle & MI & PRB (H-ESP/TOX) & Monticello & $\mathrm{TX}$ & Lignite (ESP/FGD) \\
\hline St. Clair & MI & Subbit (C-ESP) & Pleasant Prairie & WI & PRB (C-ESP) \\
\hline Laskin & $\mathrm{MN}$ & PRB & Laramie River & WY & Subbit (SDA/FF) \\
\hline Meramac & MO & Bit (ESP) & Dave Johnston & WY & Subbit \\
\hline $\begin{array}{l}{ }^{1} \text { Lists controls curre } \\
{ }^{2} \mathrm{LS}-\text { or HS-Bit }=\mathrm{LC} \\
{ }^{3} \mathrm{FF}=\text { fabric filter. } \\
{ }^{4} \mathrm{H}-\text { or C-ESP = hot } \\
{ }^{5} \text { Subbit = subbitum } \\
{ }^{6} \mathrm{FGD}=\text { flue gas de } \\
{ }^{7} \mathrm{SDA}=\text { spray dryer } \\
{ }^{8} \mathrm{PRB}=\text { Powder Ri } \\
{ }^{9} \mathrm{TOX}=\text { TOXECOI }\end{array}$ & $\begin{array}{l}\text { tly insta } \\
\text { w-or hig } \\
\text { or cold- } \\
\text { lous. } \\
\text { llfurizati } \\
\text { absorber } \\
\text { ar Basin. } \\
\text { II. }\end{array}$ & $\begin{array}{l}\text { ed. } \\
\text { sulfur bituminous. } \\
\text { de electrostatic precipitator. }\end{array}$ & & & \\
\hline
\end{tabular}

the Electric Power Research Institute, Inc. (EPRI) (27). Under the agreement, ADA-ES has acquired from EPRI license rights for the use, manufacture, distribution, lease, and sale of equipment required to implement the TOXECON II process in both the United States and Canada. The TOXECON II process uses activated carbon to reduce mercury emissions in an innovative low-capital-cost configuration that prevents contamination of the ash. This technology is geared for power plants that need to reduce mercury emissions by $50 \%$ to $90 \%$ but want to continue to sell their ash for use in concrete. ADA-ES will install equipment and perform two additional full-scale demonstrations of TOXECON II as part of a $\$ 5.5$ million program funded by DOE NETL. Tests will be completed this fall at Entergy's Independence Steam Electric Station with Powder River Basin coal. This will be followed by a test on eastern bituminous coal that will be conducted at an American Electric Power Service Corporation site in 2006. 
ADA-ES announced on June 26, 2006 (28), that it was awarded a contract, along with ALSTOM Power, Inc., to supply a mercury emission control system for a new power plant being built in Arkansas. LS Power sited a new plant to produce 680 gross megawatts of power and burn subbituminous coal from the Powder River Basin area of Wyoming. The mercury emission control system will utilize PAC to remove mercury from the flue gas of the power plant. On April 11, 2006, ADA-ES, Inc., announced that it was awarded a contract, along with ALSTOM Power, Inc., to supply a mercury emission control system for a new power plant unit. Omaha Public Power District is building a new unit at its Nebraska City plant that will produce 650 to 660 megawatts of power and burn Powder River Basin coal. The mercury emission control system will utilize PAC to remove mercury from the flue gas of the power plant.

Another developer of activated sorbents for the mercury control market is Sorbent Technologies (29). Sorbent Technologies promotes brominated activated carbon sorbents for low-halogen applications (B-PAC), high-temperature ESP applications (H-PAC), and concretefriendly applications (C-PAC).

Babcock Power Environmental Inc. (BPEI) through an agreement with Rheinbraun provides Activated Lignite $\mathrm{HOK}^{\mathrm{TM}}$, an alternative to activated carbon. This product is derived from brown coal from Germany and has a lower surface area than standard activated carbon (300 $\mathrm{m}^{2} / \mathrm{g}$ versus $500-700 \mathrm{~m}^{2} / \mathrm{g}$ ). Activated HOK can be used for mercury control in coal-fired power plants, as well as gas-cleaning processes in municipal waste and industrial waste refuse incineration plants (30).

\section{Antidumping Petition}

An antidumping petition was filed with the U.S. ITC on March 8, 2006. Primary petitioners were Calgon and Norit. The petition alleged that the activated carbon industry in the United States was materially injured due to less than fair value imports of activated carbon from China, which included both steam-activated and chemically activated carbon. As a result of that filing, the Commission instituted its investigation. This action was taken after a previous filing on January 26, 2006, that was withdrawn on February 15, 2006. The preliminary findings indicated that activated carbon imported from China is sold in the United States at less than fair value.

A group of U.S. importers of activated carbon from China, referred to as the Coalition of Importers of Activated Carbon (CIAC) includes fourteen member organizations, who were also involved in the preliminary antidumping investigation. Those importers included Carbon Link Corp.; PICA USA; Cherishmet, Inc.; Jacobi Carbons; Nichem Co.; Nucon International, Inc.; Sorbent Technologies Corp.; Superior Absorbents, Inc.; Tea Importers, Inc.; U.S. Filgers/Ionpure, Inc.; Unisorb Corp.; Bestac International, Inc.; Cal Pacific Carbon; and General Carbon.

Additionally, another group of importers and wholesalers/distributors of activated carbon from China, the CAC group, were less involved than the CIAC in the investigation and consisted of thirteen members. They are Carbon Activated Corp.; Carbon Activated Corp.; Carbon Resources; Clean Environmental Concepts; KX Industries; ML Ball Company; Solid Industrial 
Group, Inc.; United Manufacturing International; Winfield Industries, Inc.; California Carbon; Global Minerals; Prominent Systems; Resin Tech; and Timemaster Trading.

A group of exporters and producers of activated carbon from China are collectively referred to as the Coalition of Chinese Producers of Activated Carbon (CCPAC). The twenty-one individual members of CCPAC are Beijing Pacific Activated Carbon Products Co., Ltd; Daneng Zhenda Activated Carbon Co., Ltd; Datong Forward Activated Carbon Co., Ltd; Datong Huaqing Activated Carbon Co., Ltd; Datong Hongtai Activated Carbon Co., Ltd; Datong Huibao Activated Carbon Co., Ltd; Datong Juqiang Activated Carbon Co., Ltd; Datong Locomotive Coal \& Chemicals Co., Ltd.; Datong Tri-Star \& Power Carbon Plant; Datong Weidu Activated Carbon Co., Ltd; Datong Yunguang Chemical Plant; Jilin Province Bright Future Industry \& Commerce Co., Ltd; Ningxia Guanghua-Cherishmet Activated Carbon Co., Ltd; Shanxi DMD Corporation; Shanxi Industry Technology Trading Co., Ltd; Shanxi Sincere Industrial Co., Ltd; Shanxi Xinhua Chemical Co., Ltd; Shanxi Xinshidai Import \& Export Co., Ltd; Shanxi Xuanzhong Chemical Industry Co., Ltd; and Tangshan Solid Carbon Co., Ltd.

Tables 18 and 19 show data provided by Chinese producers/exporters with respect to their activated carbon operations in China. Twenty-four firms, 19 of which exported activated carbon to the United States, provided usable data to the ITC. The exports to the United States of these firms were equivalent to $56.4 \%$ of the activated carbon the United States imported from China in 2005. Seventeen firms noted that activated carbon represented $100 \%$ of their firm's total sales in 2005, with only two noting that it represented less than $50 \%$.

Table 18. Activated Carbon: Chinese Production Capacity, Production, Shipments, and Inventories, Quantity, 1000 pounds*

\begin{tabular}{|c|c|c|c|c|c|}
\hline & \multicolumn{3}{|c|}{ Actual Experience (2003-2005) } & \multicolumn{2}{|c|}{ Projections (2006-2007) } \\
\hline Item & 2003 & 2004 & 2005 & 2006 & 2007 \\
\hline Capacity & 197,475 & 245,235 & 274,115 & 274,520 & 277,520 \\
\hline Production & 181,279 & 228,943 & 260,851 & 266,147 & 268,356 \\
\hline $\begin{array}{c}\text { End of Period } \\
\text { Inventories }\end{array}$ & 20,459 & 16,4692 & 6199 & 22,349 & 20,042 \\
\hline $\begin{array}{l}\text { Shipments: Internal } \\
\text { Consumption }\end{array}$ & 0 & 4951 & 6991 & 7120 & 6920 \\
\hline Home Market & 72,872 & 151,834 & 179,848 & 184,631 & 191,931 \\
\hline $\begin{array}{l}\text { Exports to the United } \\
\text { States }\end{array}$ & 38,619 & 57,991 & 46,813 & 42,826 & 41,825 \\
\hline $\begin{array}{l}\text { Exports to All Other } \\
\text { Markets }\end{array}$ & 119,883 & 147,080 & 146,092 & 149,844 & 144,892 \\
\hline Total Exports & 158,502 & 205,071 & 192,905 & 192,670 & 186,717 \\
\hline Total Shipments & 231,374 & 361,856 & 379,744 & 384,421 & 385,568 \\
\hline
\end{tabular}


Table 19. Activated Carbon: Chinese Production Capacity, Production, Shipments, and Inventories, Ratios and Shares, \%*

\begin{tabular}{llllll}
\hline & \multicolumn{3}{c}{ Actual Experience (2003- } & \multicolumn{2}{c}{$\begin{array}{c}\text { Projections (2006- } \\
\text { 2007) }\end{array}$} \\
\hline & 2003 & 2004 & 2005 & 2006 & 2007 \\
\hline Capacity Utilization & 90.8 & 90.7 & 92.0 & 93.7 & 93.5 \\
Inventories to Production & 11.3 & 7.2 & 10.0 & 8.4 & 7.5 \\
Inventories to Total Shipments & 8.8 & 4.6 & 6.9 & 5.8 & 5.2 \\
Share of Total Quantity of Shipments: & & & & & \\
$\quad$ Internal Consumption & 0.0 & 1.4 & 1.8 & 1.9 & 1.8 \\
$\quad$ Home Market & 31.5 & 42.0 & 47.4 & 48.0 & 49.8 \\
$\quad$ Exports to the United States & 16.7 & 16.0 & 12.3 & 11.1 & 10.8 \\
$\quad$ Exports to All Other Markets & 51.8 & 40.6 & 38.5 & 39.0 & 37.6 \\
$\quad$ All Export Markets & 68.5 & 56.7 & 50.8 & 50.1 & 48.4 \\
\hline
\end{tabular}

* Because of rounding, figures may not add to the totals shown (compiled from data submitted in response to International Trade Commission questionnaires [16]).

\section{Industry Capacity}

From 2003 to 2005, reported Chinese capacity grew from 197.5 million pounds to 274.1 million pounds (Tables 18 and 19). Production more than kept pace with the growth in capacity as capacity utilization rose from $90.8 \%$ in 2003 to $92.0 \%$ in 2005 . These data indicate that Chinese suppliers of activated carbon have some excess capacity with which they could increase production of activated carbon in the event of a price change.

\section{Channels of Distribution}

According to questionnaire responses from Chinese producers of activated carbon, exports to the United States accounted for $24.3 \%$ of all exports of activated carbon from China in 2005, down from $28.3 \%$ in 2004 (16). Both U.S. producers' U.S. commercial shipments of activated carbon as well as U.S. shipments of imported product from China are made primarily to end users (16). Types of end users include municipal water treatment facilities, food processing plants, and chemical processing plants. Markets do not appear to be limited geographically as the large producers sell nationwide.

The U.S. activated carbon market relies on a distribution network similar to other specialty chemicals, one that stresses direct sales but also utilizes general distributors, resellers, and manufacturers' representatives. Direct sales are important to large activated carbon producers. The product is sold primarily on the basis of price, purity, dependability of delivery, and service. Calgon Carbon, the leading U.S. producer, operates primarily through a direct sales force in North America, Europe, and the Far East. In addition to direct sales, distributors are widely used in the activated carbon market. For instance, even though Calgon Carbon operates an extensive direct sales force with seven offices in the United States and one in Canada, the company also employs distributors and agents to promote its product. Clack (Lindon, Utah), for example, is among the many distributors of Calgon Carbon products in the United States. 
Distributors are generally used in the activated carbon market to reach small customers or remote areas. Generally, these distributors maintain their own storage and delivery facilities and buy for their own accounts. General distributors provide advantages for chemical users. They provide a single point of contact between the customer and numerous chemical manufacturers. Distributors can be contacted quickly for provision of "just-in-time" delivery, helping to control inventory problems. In the Plains area, when searching and inquiring about those participating in the bid process for activated carbon, the most frequently appearing name is Norit.

Other distribution channels used in the U.S. activated carbon market include resellers and manufacturers' representatives. There are resellers in the United States that purchase low-cost bulk activated carbon from producers located in China. These companies then further process the carbon and resell it on the U.S. market. Manufacturers' representatives help reach small, geographically scattered companies not easily reached directly by the producer.

So, in the existing market for water treatment, there are direct sales by producers along with resellers and manufacturers' representatives as just mentioned. For example, Res Kem of Pennsylvania is a distributor of activated carbon. A manufacturer's representative close to North Dakota is Thatcher of Montana. Thatcher distributes product but does not manufacture activated carbon. It carries product from China obtained through a distributor in New York, and it also carries Cal Pacific product from California. Thatcher participates in the bid processes and its name shows up in regional bidding.

East Grand Forks, Minnesota, sends out invitations to vendors to bid. East Grand Forks typically works with the following vendors: Cal Pacific, Hawkins, Carbochem, Thatcher, and Unibar USA. It follows the AWWA specifications. It does not bid on any foreign products other than Canadian because of Homeland Security requirements. Price is a major factor in the bid decision; however, other issues are important too. It has dropped a supplier in the past. Typical problems include slow delivery and broken bags and damaged containers. Sometimes the product doesn't meet standards. A historical example happened in Grand Forks, North Dakota. A low bidder won a contract, but its product clogged the system and had to be discontinued (31).

In the Plains region, surface water plants use activated carbon in North Dakota, Minnesota, South Dakota, Montana, and Wisconsin. Any plants with taste and odor problems would be interested in activated carbon. In the area surrounding Grand Forks, surface water plants using activated carbon are Grand Forks, East Grand Forks, Thief River Falls, Bismarck, Minot, Fergus Falls, and Minneapolis (31). Since the mercury control market is an emerging one, the supply chain is not yet known.

\section{China - Channel of Distribution}

A share of importers' U.S. shipments went to distributors, with shipments to end users accounting for between $64 \%$ and $74 \%$ of U.S. imports from China during the period 2003 to 2005 (16). A respondent in the ITC investigation suggested that sales to distributors are often made at a discount because of the lower cost of sale involved in such transactions. To the extent that this is true, it may place a downward bias on the observed price of imported activated carbon 
Table 20. Activated Carbon: U.S. Producers' and U.S. Importers’ U.S. Shipments by Channels of Distribution, 2003-2005*

\begin{tabular}{lrrr}
\hline Shipments & 2003 & 2004 & 2005 \\
\hline U.S. Importers’ Subject U.S. Shipments (in short tons) & & & \\
To Distributors & 14,879 & 22,308 & 26,235 \\
To End Users & 42,093 & 49,698 & 46,834 \\
Share of U.S. Importers' Subject U.S. Shipments (in \%) & & & \\
$\quad$ To Distributors & 26.1 & 31.0 & 35.9 \\
To End Users & 73.9 & 69.0 & 64.1 \\
\hline
\end{tabular}

* Compiled from data submitted in response to International Trade Commission questionnaires (16).

that is more frequently sold to distributors. Table 20 presents information on channels of distribution for U.S. producers as well as for U.S. imports of subject product from China. The importers of Chinese activated carbon were provided in an earlier section.

\section{Price}

It is generally agreed that as long as activated carbon meets the specifications required for the specific end use in question, price is the largest single factor affecting purchase decisions.

\section{Raw Materials}

The production of activated carbon begins with some material that contains a high level of carbon. Such materials include, but are not limited to, coal (both bituminous and lignite), wood, coconut shells, olive stones, and peat. According to petitioners, coal is the raw material most widely used by both U.S. and Chinese producers of activated carbon. As shown in Figure 24, the price of coal has risen over the period for which data were collected. Prices in the fourth quarter of 2005 were 50\% higher than they were in the first quarter of 2003. Other raw materials used in the production process include pitch, phosphoric acid, oxygen, steam, and water.

\section{Transportation Costs to the U.S. Market}

Transportation costs for activated carbon from China to the United States (excluding U.S. inland costs) in 2005 are estimated to be equivalent to approximately $24.4 \%$ of the customs value for product from China. These estimates were derived by the ITC using official import data and represent the transportation and other charges on imports valued on a c.i.f. basis, as compared with customs value (16).

\section{U.S. Inland Transportation Costs}

Reported U.S. inland transportation costs ranged from $0 \%$ to $30 \%$ for the 30 reporting Chinese importers with all but two reporting transportation costs of $20 \%$ or less. Producers and importers questioned in the ITC investigation also were asked to estimate the percentage of their sales that occurred within distance ranges. Seven of 31 responding importers reported shipping at least $50 \%$ of their sales more than 1,000 miles; 16 reported shipping at least $50 \%$ of their sales 




Figure 24. Average domestic price of coal to industrial plants, 2003-2005 (32).

between 100 and 1000 miles; and seven reported shipping at least $50 \%$ of their sales less than 100 miles, with three of those shipping $100 \%$ of their sales less than 100 miles.

\section{Pricing Methods}

Activated carbon is sold on both a spot and a contract basis. Six of 29 responding importers reported that $100 \%$ of their sales were on a spot basis, with eight more reporting that at least $50 \%$ of their sales were on a spot basis. Seventeen of the responding importers reported that at least half of their sales were made on a contract basis. Eight importers reported that at least $50 \%$ of their sales were on a long-term contract basis while six reported that more than $50 \%$ of their sales were on a short-term contract basis. While a majority (22 of 31) of responding importers reported determining price on at least some of their sales on a transaction-bytransaction basis, seven reported using a price list for some (usually the smaller) or all of their customers. Sixteen responding importers reported giving discounts based on, among other things, quantity, long-term orders, and early payment. Ten importers reported that they have no discount policy. The ITC requested U.S. producers and importers of activated carbon provide quarterly data for the total quantity and f.o.b. (U.S. point of shipment) value of activated carbon that was shipped to unrelated customers in the U.S. market. Data were requested for the period January 2003 to December 2005. The product is defined as "powder activated carbon that is steam activated from coal (bituminous or lignite), unwashed, particle size $90 \%$ min, 325 mesh, iodine no. $700 \mathrm{mg} / \mathrm{g}$ min, moisture 5\% max" (16).

Three U.S. producers and 21 importers of activated carbon from China provided usable pricing data for sales of the requested products to the ITC as part of the antidumping investigation, although not all firms reported pricing for all quarters. The tables below present f.o.b. (U.S. point of shipment) selling prices for the three activated carbon products defined 
above produced and sold in the United States as well as products produced in China and imported into the United States. By quantity, pricing data reported by responding firms in 2003 through 2005 accounted for $49.8 \%$ of U.S. commercial shipments of U.S.-produced activated carbon and $35.7 \%$ of U.S. commercial shipments of Chinese-produced activated carbon (16) (Table 21).

The ITC made its final determination regarding the antidumping investigation in March 2007 (33). The result is an added duty on activated carbon imported from China, resulting in an average $72 \%$ total tariff (34). The tariffs have resulted in large price increases in activated carbon.

\section{Water Treatment Applications - Pricing and Bid Process}

The primary question posed at the beginning of the research is how municipal water treatment facilities obtain their activated carbon. After contacting several facilities along with searches of publicly available bid data, the conclusion is that it is indeed a bid process. Typically, it is an annual process; however, sometimes contracts are awarded for 2 years. Usually, the lowest bidder wins the contract; however, there are instances where the specifications do not meet the buyers' needs or the quality is not suitable. Bidders may be domestic producers of activated carbon, resellers, or importers of activated carbon from Asia. Price per ton for PAC ranges from \$630/ton at the low end to above \$1000/ton at the high end. The following are examples of bid data obtained.

Table 21. Weighted Average F.O.B. Prices and Quantities of Domestic and Imported PAC by Quarters, January 2003 - December 2005*

\begin{tabular}{lcc}
\hline Period & Price, $\$ /$ lb & Quantity, 1000 pounds \\
\hline 2003: & 0.31 & 488,728 \\
Jan. - Mar. & 0.28 & $1,251,826$ \\
Apr. - June & 0.25 & $2,366,105$ \\
July - Sept. & 0.33 & 747,460 \\
Oct. - Dec. & & \\
2004: & 0.26 & 873,934 \\
Jan. - Mar. & 0.25 & $2,289,210$ \\
Apr. - June & 0.26 & $2,011,196$ \\
July - Sept. & 0.29 & $1,257,643$ \\
Oct. - Dec. & & \\
2005: & 0.27 & $1,555,839$ \\
Jan. - Mar. & 0.26 & $1,829,518$ \\
Apr. - June & 0.29 & $3,303,809$ \\
July - Sept. & 0.29 & $2,584,640$ \\
Oct. - Dec. & &
\end{tabular}




\section{Examples of Water Treatment Bid Pricing}

An example is of a 2-year contract for the City of Saginaw, Michigan (35), which is a contract for PAC for 50 tons from July 1, 2006, to June 30, 2008. It was an increase of 4.8\% over the previous year.

\begin{tabular}{|c|c|c|}
\hline \multirow{2}{*}{\multicolumn{3}{|c|}{ Carbon Activated Corp $\underline{\text { Per Ton }}$}} \\
\hline & & \\
\hline Year One & $\$ 670$ & $\$ 33,500$ \\
\hline Year Two & $\$ 699$ & $\$ 34,950$ \\
\hline \multicolumn{3}{|l|}{ Envirotrol } \\
\hline Year One & $\$ 748$ & $\$ 37,400$ \\
\hline Year Two & $\$ 768$ & $\$ 38,400$ \\
\hline \multicolumn{3}{|l|}{ Nichem Company } \\
\hline Year One & $\$ 810$ & $\$ 40,500$ \\
\hline Year Two & $\$ 810$ & $\$ 40,500$ \\
\hline \multicolumn{3}{|c|}{ Calgon Carbon Corp. } \\
\hline Year One & $\$ 780$ & $\$ 39,000$ \\
\hline Year Two & $\$ 858$ & $\$ 42,900$ \\
\hline \multicolumn{3}{|c|}{ Norit Americas Inc. } \\
\hline Year One & $\$ 1120$ & $\$ 56,000$ \\
\hline Year Two & $\$ 1160$ & $\$ 58,000$ \\
\hline
\end{tabular}

The following list shows an example of a bid outcome for PAC, where Norit was the winner in Lawrence, Kansas, 1 year, while Cal Pacific had the lowest bid in 2006 (36). This exemplifies the upward trend in PAC prices.

Norit

Cal Pacific

GS Robins \& Co.

Univar

Carbon USA

Cal Pacific Carbon

Carbon Solutions

G.S. Robins \& Co.

Norit

\begin{tabular}{c} 
Per Ton -2005 \\
\hline$\$ 634$ \\
$\$ 680$ \\
$\$ 664$ \\
$\$ 713.40$ \\
$\$ 746$
\end{tabular}

\begin{tabular}{c} 
Per Ton -2006 \\
\hline$\$ 800$ \\
$\$ 1200$ \\
$\$ 1600$ \\
$\$ 1620$
\end{tabular}

\section{Identification of Barriers to Market Entry}

The first challenge to market entry is developing the PAC and GAC products. However, that is progressing well. It is now a matter of testing and demonstrating the product. 
The next challenge to market entry is establishing a presence in the marketplace. Norit and Calgon Carbon are well-established market leaders with well-known brands. Activated carbon producers offer many proprietary grades of activated carbon marketed under well-established trade names, making brand name recognition and product loyalty significant industry factors. Examples of well-known trade names in the activated carbon market include SULFUSORB and XTRUSORB from Calgon Carbon, DARCO from Norit Americas and NUCHAR from MeadWestvaco (15). Thus, brand name recognition presents a barrier to entry into the U.S. activated carbon industry

Activated carbon producers also use service as a way to differentiate their product and company. Calgon Carbon, for instance, stresses its ability to provide not only the carbon purification medium, but also the complete equipment design. The company's strategy is based on close monitoring of quality, productivity, safety, and the environment. This includes close supervision of the work of the component manufacturers, direct control of all phases of equipment assembly and testing, and supervision of equipment start-up (15).

In the water treatment market, municipal water treatment is typically based on a bid process. There are certainly opportunities for new entrants to the marketplace who are able to meet the activated carbon specifications at a competitive price, giving them the opportunity of winning the bid process.

\section{Recommendations for Market Strategies}

\section{Market Segmentation Focus}

A focus strategy involves dividing the market into segments or products and then focusing on a particular buyer group. This strategy is based on the notion that narrow, strategic markets are more effectively served than the entire industry. Producers of activated carbon may focus on either granular- or powder-type activated carbon and may also focus more on either gas-phase or liquid-phase applications. Among the two world market leaders, Calgon Carbon is primarily GAC, while Norit Americas is focused mainly on powdered types. Therefore, Norit is the primary competition for the proposed enterprise.

Because most municipalities operate under a closed-bid system, a company's sales department is responsible for determining when contracts are due to expire and then establishing a new bid for the municipality. Beyond these considerations, activated carbon producers tend to focus on servicing those markets in which they hold or can reasonably hope to gain a significant strategic advantage. Thus the regional market of North Dakota and surrounding states would be an advisable focus area with a transportation cost advantage for the proposed enterprise.

At the end-use level, producers have numerous opportunities for focus strategies. Mercury control is going to be the growing focus area for an activated carbon enterprise. In the mercury control market, two characteristics are going to dominate the customer's buying habitperformance and price. As continued demonstration testing of activated carbon injection at the 
various coal-fired power plants progresses, the importance of fuel type and plant configuration on the type of activated carbon best suited is being identified.

For example, for low-chlorine coals such as lignite and Powder River Basin subbituminous, a halogen-enhanced activated carbon provides the best price performance. For coal-fired plants equipped with fabric filters, plain activated carbon is likely more cost-effective and the iodine number (surface area) may be the more important characteristic. For applications where the ash has to be used in concrete, there is a need for a concrete-friendly carbon that has a low propensity to adsorb air-entraining additives during concrete manufacturing. The proposed enterprise would need to develop these and other tailored products for the mercury control market. With the expertise available at the EERC and its partners, this is a feasible objective.

\section{Low Price Leader}

Low-price leadership is also a major competitive strategy. One of the advantages is that the raw material cost is lower if the location of the plant is in close proximity to the mine because of low mining and transportation costs. In the state of North Dakota, there is an available, low-cost labor pool with a good work ethic. Transportation costs within regional markets would also be minimized. All of these allow a proposed plant to manufacture activated carbon at a competitive cost advantage and would enable it to be cost-competitive in the commodity market for water treatment. The more specialty market for mercury control would offer better pricing, and margins would contribute to increased profitability and growth.

Figure 25 summarizes the product mix, market penetration, and growth strategy for such an enterprise.

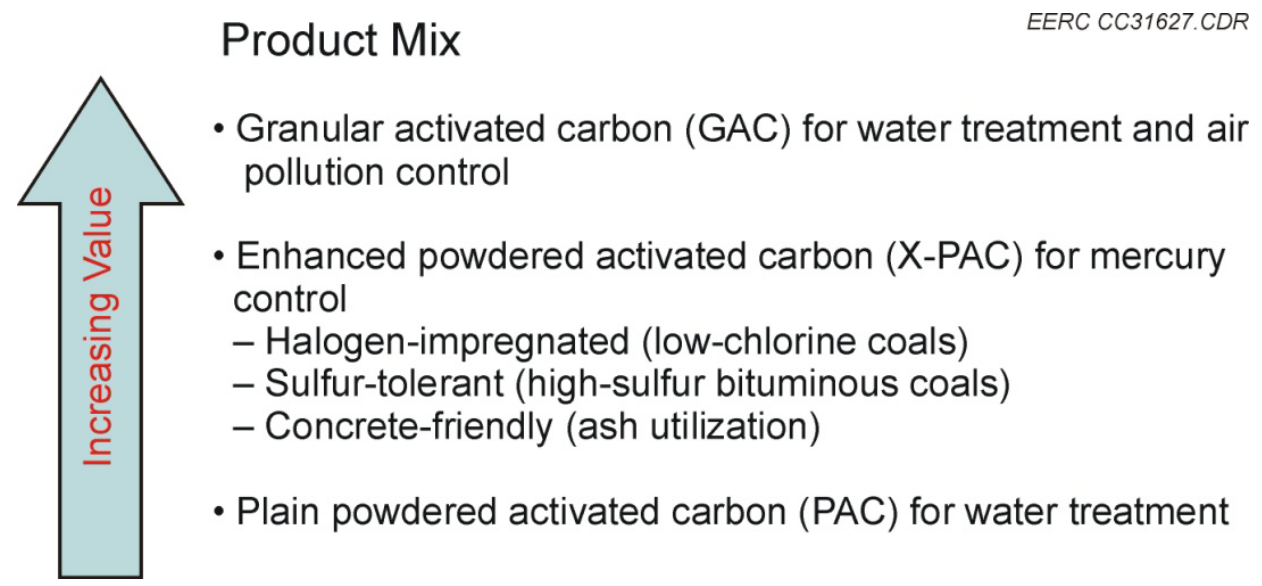

Figure 25. Product mix and penetration and growth strategy for a North Dakota-based manufacturer of activated carbon. 


\section{Existing Municipal Water Treatment Market}

Municipal water treatment in the upper Great Plains is a prospective initial customer base for a start-up production facility. Municipal water treatment professionals meet periodically, and there are opportunities for presenting new products to them. In fact, within North Dakota, the EERC is already invited to attend several upcoming meetings. One of the metro areas in North Dakota would be a logical strategic partner for demonstration of the new PAC product for water treatment.

The easiest way to enter the market for water treatment is to participate in the competitive bidding process. Most contracts are on an annual basis. Usually there is approximately 90 days to respond to a request. So, it is recommended to prepare well in advance to participate in the bidding process, or the opportunity will pass until the following year.

In speaking with the Grand Forks municipal purchasing agent for activated carbon, she suggested the possibility that if a local product were available, there could be an opportunity for purchase by a group of municipalities.

\section{Emerging Market - Mercury}

One of the best ways for penetrating the emerging mercury market is to test and demonstrate the various activated carbon specialty sorbents at different plants and with different fuels. The EERC and its partners are already performing several mercury control demonstrations at various sites. Even during the sorbent formulation development phase, for example, when smaller quantities of sorbent are manufactured in the pilot plant, various formulations should be made available for testing in these demonstration projects.

\section{Networking}

Networking in existing activated carbon groups would also be helpful, particularly for the existing water treatment market. For example, there is an International Activated Carbon Manufacturers Association. They meet several times per year and also offer short courses.

Exhibition at upcoming conferences could be a useful strategy. Upcoming conferences noted by Professional Analytical and Consulting Services (37) include the following:

- Madrid, Spain: 21st International Activated Carbon Conference (July 3-4, 2008) and Courses (July 1-9, 2008)

- Pittsburgh, Pennsylvania: 22nd International Activated Carbon Conference (October 78, 2008) and Courses (October 1-13, 2008)

Becoming members of trade associations such as the American Water Works Association (AWWA) would also add benefit for showcasing the proposed enterprise's products and gaining traction in this market. 


\section{CONCLUSIONS}

The EERC produced activated carbon from North Dakota lignite from the Center Mine, which was comparable or superior to commercial-grade activated carbon (DARCO FGD) for both surface area and mercury removal. The lab-scale activated carbon production process was successfully upgraded to a pilot-scale rotary kiln system. Optimization of both carbonization and steam activation processes was conducted in both the lab-scale and pilot-scale systems. The EERC performed bench-scale and pilot-scale mercury capture tests, and a slipstream baghouse test was performed at a Texas power plant using activated carbon made at various process optimization conditions. A conceptual design of a commercial activated carbon production plant was developed, and a market analysis of the activated carbon produced from such a carbon production plant was conducted. The EERC made the following conclusions based on the information gathered from research conducted for this project:

- Of those tested, the optimum carbonization temperature was determined to be $600^{\circ} \mathrm{C}$.

- Optimum steam activation process conditions were $900^{\circ} \mathrm{C}$ and 90 -min residence time.

- Activated carbon made at the EERC from Hagel A lignite coal was superior to commercial DARCO FGD in surface area and comparable for mercury removal in pilot-scale applications.

- The iodine number of the EERC-produced activated carbon was between 600 and 800 mg $\mathrm{I}_{2} / \mathrm{g}$, where the iodine number of DARCO FGD was between 500 and $600 \mathrm{mg} \mathrm{I} / \mathrm{g}$, and the iodine number of Rheinbraun's HOK activated coke product was around 275 $\mathrm{mg} \mathrm{I}_{2} / \mathrm{g}$.

- Activated carbon made at the EERC at $900^{\circ} \mathrm{C}$ and a 90 -min residence time was more effective at mercury capture than commercial DARCO FGD in pilot-scale combustion tests.

- MHF technology was selected as the most promising for carbon production.

- The water treatment commodity market exists and is large enough to accommodate extra supply. This market will provide the base market for EERC-derived activated carbon.

- Mercury control is an emerging application that will be implemented in the U.S. utility industry, and the market will involve both existing and new power plants.

- The mercury control market will provide expanded, high-value market opportunities over and above the water treatment market.

- The activated carbon produced from North Dakota Center lignite would represent a viable and competitive product in the market. 


\section{REFERENCES}

1. Benson, S.A.; Crocker, C.R.; Galbreath, K.C.; Gunderson, J.R.; Holmes, M.J.; Laumb, J.D.; Mackenzie, J.M.; Olderbak, M.R.; Pavlish, J.H.; Yan, L.; Zhuang, Y. Pilot- and Full-Scale Demonstration of Advanced Mercury Control Technologies for Lignite-Fired Power Plants; Final Report for U.S. Department of Energy National Energy Technology Laboratory Cooperative Agreement No. DE-FC26-03NT41897 and Multiclients; EERC Publication 2005-EERC-02-05; Energy \& Environmental Research Center: Grand Forks, ND, Feb 2005.

2. Pavlish, J.H.; Holmes, M.J.; Benson, S.A.; Crocker, C.R.; Olson, E.S.; Galbreath, K.C.; Zhuang, Y.; Pavlish, B.M. Mercury Control Technologies for Electric Utilities Burning Lignite Coal, Phase I Bench- and Pilot-Scale Testing; Final Report for U.S. Department of Energy Environmental Management Contract No. DE-FC26-98FT40321; Energy \& Environmental Research Center: Grand Forks, ND, Oct 2003.

3. Standards of Performance for New and Existing Stationary Sources: Electric Utility Steam Generating Units, amended. Code of Federal Regulations, Parts 60, 63, 72, and 75, Title 40, 2005.

4. Rule to Reduce Interstate Transport of Fine Particulate Matter and Ozone (Clean Air Interstate Rule); Revisions to Acid Rain Program; Revisions to the $\mathrm{NO}_{\mathrm{x}}$ SIP Call. Code of Federal Regulations, Parts 51, 72, 73, 77, 78, and 96, Title 40, 2005.

5. Standards of Performance for New and Existing Stationary Sources: Electric Utility Steam Generating Units. Code of Federal Regulations, Part 60 subpart Da, 63, 72, and 75, Title 40, 2005.

6. Office of Air and Radiation U.S. Environmental Protection Agency. Technical Support Document for the Clean Air Mercury Rule Notice of Final Rulemaking State and Indian Country Emissions Budgets. www.epa.gov/ttn/atw/utility/state_indiancountry_emissionbudgets_oar-2002-0056-6154.pdf (accessed Apr 2005), p 6.

7. Pavlish, J.H.; Sondreal, E.A.; Mann, M.D.; Olson, E.S.; Galbreath, K.C.; Laudal, D.L.; Benson, S.A. Status Review of Mercury Control Options for Coal-Fired Power Plants. Fuel Process. Technol. 2003, 82 (2-3), 89-165.

8. $\quad$ Bansal, R.C.; Bonnet, J.-B.; Stoeckli, F. Active Carbon; Marcel Dekker: New York, 1988; p 20.

9. Pavlish, J.H.; Holmes, M.J.; Benson, S.A.; Crocker, C.R.; Galbreath, K.C. Mercury Control Technologies for Utilities Burning Lignite Coal. In Proceeding of Air Quality III: Mercury, Trace Elements, and Particulate Matter Conference; Sept 9-12, 2002.

10. Bustard, J.; Durham, M.; Starns, T.; Lindsey, C.; Martin, C.; Schlager, R.; Bladrey, K. FullScale Evaluation of Sorbent Injection for Mercury Control on Coal-Fired Power Plants. In 
Proceedings of Air Quality III: Mercury, Trace Elements, and Particulate Matter Conference; Sept 9-12, 2002.

11. AWWA standards for PAC for water treatment. ANSI/AWWA B600, Powdered Activated Carbon (rev. 10/05).

12. www.NORIT-americas.com/pdf/Hg_rev4.pdf (accessed Feb 7, 2008).

13. www.NORIT-americas.com/pdf/Hg_LH_rev4.pdf (accessed Feb 7, 2008).

14. AWWA standards for PAC for water treatment. ANSI/AWWA B604, Granular Activated Carbon (rev. 03/06).

15. Activated Carbon, Industry Study. 2002. The Freedonia Group, Cleveland, OH.

16. Certain Activated Carbon from China. May, 2006. Preliminary Investigation No. 731-TA1103, U.S. International Trade Commission.

17. Control of Mercury Emissions from Solid Fuel Combustion, U.S. Patent 6,848,374.

18. U.S. Environmental Protection Agency, www.epa.gov/mercuryrule/basic.htm.

19. http://library.corporate-ir.net/library/89/890/89025/items/213368/Stanford906.pdf (accessed Aug 2006; Feb 8, 2008).

20. http://finance.breitbart.com/breitbart?ID=3434839\&Page=NewsRead (accessed Feb 7, 2008).

21. www.netl.doe.gov/coal/refshelf/ncp.pdf (accessed Aug 2006).

22. Mcllvaine Company, www.mcilvainecompany.com (accessed Aug 2006).

23. www.epa.gov/EPA-WATER/2006/January/Day-04/w03.htm (accessed Feb 11, 2008).

24. Thelan, Larry, Program Administrator. Drinking Water Program, North Dakota Department of Health. Personal communication, April 2006.

25. www.netl.doe.gov/technologies/coalpower/ewr/mercury/index.html (accessed Aug 2006).

26. www.netl.doe.gov/technologies/coalpower/ewr/mercury/control-tech/sorbentinjection3.html (accessed Feb 7, 2008).

27. ADA-ES Licenses TOXECON II ${ }^{\mathrm{TM}}$ Mercury Removal Process. Aug 2005. www.pollutiononline.com/content/news/article.asp?docid=\{47e50e1f-0e24-4ad9-8ede78e46687a247\} (accessed Aug 2006). 
28. adaes.org. Press Releases section (accessed Feb 7, 2008).

29. www.sorbenttechnologies.com/coldside.html. (accessed Feb 7, 2008).

30. www.babcockpower.com/index.php?option=products\&task=viewproduct\&coid=17\&proid $=46$ (accessed Feb 7, 2008).

31. Sletten, Hazel, Water Utility Superintendent. City of Grand Forks, ND. Personal communication, April 2006.

32. Quarterly Coal Reports (various issues, 2003-2005) Table 25 - Average Price of Coal Receipts at Other Industrial Plants. Energy Information Administration, Office of Coal, Nuclear, Electric, and Alternate Fuels, U.S. Department of Energy. Available at http://tonto.eia.doe.gov/FTPROOT/coal/qcrhistory.htm (accessed Feb 6, 2008).

33. Certain Activated Carbon from China Investigation No. 731-TA-1103 (Final) http://hotdocs.usitc.gov/docs/pubs/701_731/pub3913.pdf (accessed Feb 7, 2008).

34. Shaeffer, Ken. 2007. Activated Carbon Market-Tariff Update or Duty Is in the Eyes of the Beholder. Water Conditioning \& Purification Magazine. www.carbonresources.com/pdf/Schaeffer_0607.pdf (accessed Feb 2008).

35. www.saginaw-mi.com/Government/Departments/CityCouncil/Agendas/6-21-04/6-2111.doc (accessed Feb 7, 2008).

36. www.lawrenceks.org/finance_bids/bidb07068.html (accessed Feb 7, 2008).

37. Professional Analytical and Consulting Services, http://pacslabs.com/ activatedcarbon/acconferences.php (accessed Feb 7, 2008). 